$$
\text { دراسة تأصيلية ناقدة في ضوء الإرشاد العقلاني الانفعالي }
$$

$$
\text { إعداد }
$$$$
\text { الدكتور / غالي بن دهيران اللقماني }
$$

أستاذ أصول التربية الإسلامية المشارك بقسم التربية بالجامعة الإسلامية بالمدينة

$$
\text { المنورة- المملكة العربية السعودية }
$$

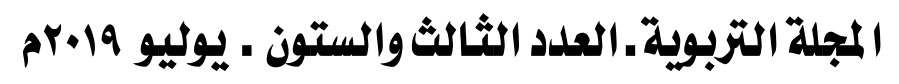

Print:(ISSN 1687-2649) Online:(ISSN 2536-9091) 


\section{المستخلص :}

هدف البحث إلى نقد نظرية الإرشاد العقلاني الانفعالي في ضوء المنهج الإسلامي، واستخدم الباحث المنهجين: الاستباطي، والتحليلي، وأسفر البحث عن النتائج التالية: اتفاق نظرية الإرشاد العقلاني الانفعالي مع نظرة المنهج الإسلامي في: حرية الفرد في استخدام طريقة

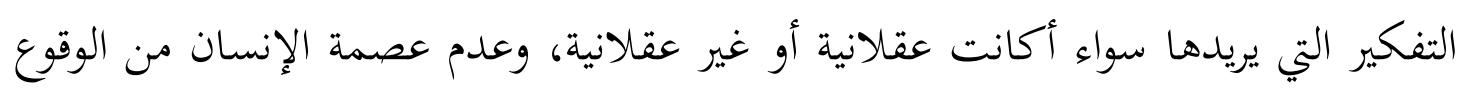
في الأخطاء ، وعدم استخدام أسلوب اللوم للنفس أو للآخرين . كما كشف البحث عن اختلاف نظرية الإرشاد العقلاني الانفعالي عن نظرة المنهج الإسلامي إلى الإنسان وقد تبيّن شمولية نظرة المنهج الإسلامي وواقعيته، كما أوضح البحث

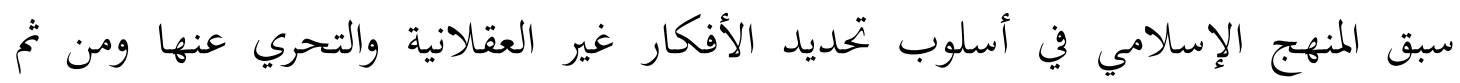
مهاجمتها كمدخل لعلاج الاضطراب ، وبيّن البحث كذلك تفوق المنهج الإسلامي في طريقة تعامله مع الأفكار غير العقلانية حيث سلك منهجين: بنائي يتمثل في بناء أفكار عقلانية

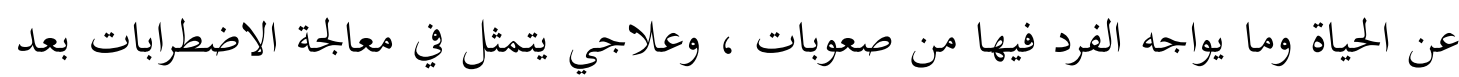
وقوعها من خلال تفنيد الأفكار غير العقلانية ومهاجمتها. الكلمات المفتاحية :

نظرية الإرشاد العقلاني الانفعالي، المنهج الإسلامي، التأصيل الإسلامي، الأفكار غير العقلانية. 


\begin{abstract}
:
The objective of the research is to critique the theory of rational rationalism In view of the Islamic approach. The researcher used the two methods: deductive and analytical. The results of the research were: The rational rational counseling agreement with the Islamic approach in the freedom of the individual to use the method of thinking that he wants, whether rational or Irrational, non-human infallibility from making mistakes, and not using blame for oneself or others.

The study also revealed the difference between the rational and emotional view of the Islamic approach to the human being and the comprehensiveness of the Islamic approach and its reality. The study also explained the Islamic method in the method of identifying irrational ideas and investigating them and then attacking them as an input to treat the disorder. In the way he deals with irrational ideas, where he took two approaches: constructive is to build rational ideas about life and the individual's difficulties, and the treatment is to deal with the turmoil after the occurrence through the refutation of irrational ideas and attack.
\end{abstract}

key words:

Rational rational counseling theory, Islamic methodology, Islamic fundamentalism, irrational ideas. 
يعدّ الإنسان محور الدراسات النفسية باختلاف جوانبها، وعلى مرّ التاريخ توجّهت الجهود

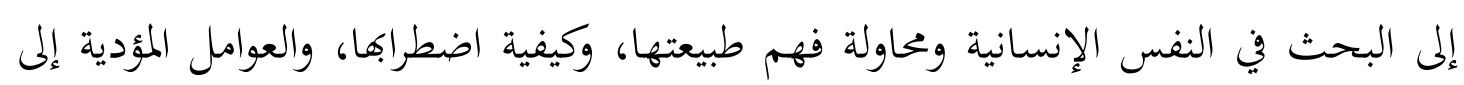

$$
\text { صحتها وكيفية علاج ما يعتريها من اضطرابات. }
$$

وفي سبيل ذلك ظهرت التفسيرات المختلفة للطبيعة الإنسانية وفهم السلوك الإنساني فنشأت نظريات الإرشاد النفسي وهي تمثّل وجهات نظر لمؤسسيها حول الطبيعة الإنسانية وكيفية

$$
\text { حدوث الاضطراب والأسلوب الأمثل للتدخل الإرشادي. }
$$

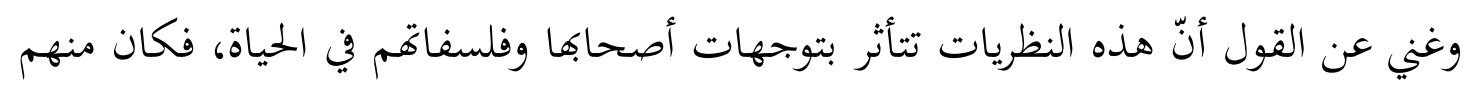

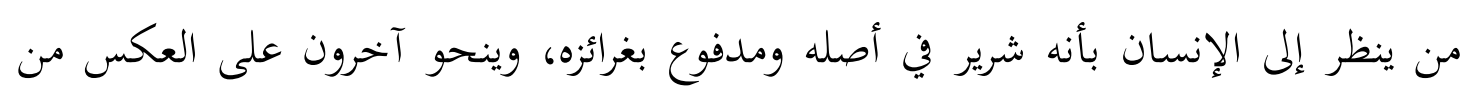
ذلك فيثبتون للإنسان الخيرة الكاملة، في حين يقف البعض الآنر في المنتصف بئن بين الفريقين فيرون الإنسان صفحة بيضاء لا خير فيها ولا شر.

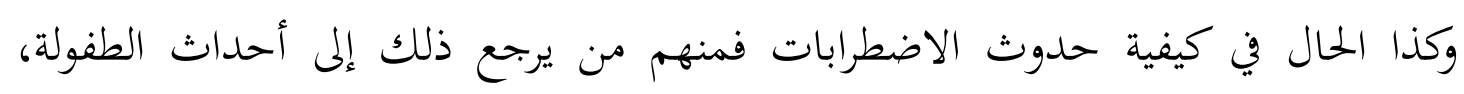

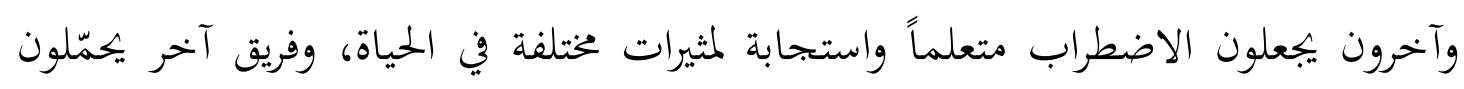
الأفكار غير العقلانية مسؤولية حدوث الاضطراب وأنّ الشخص هو من يسهم في اضطرابه بسبب طريقة تفكيره غير العقلانية.

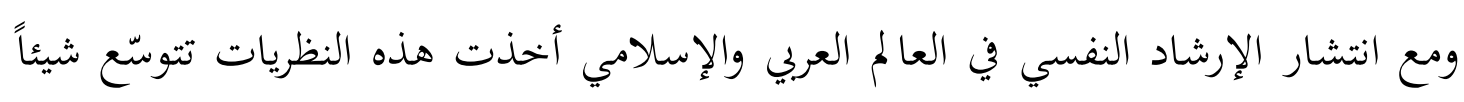
فشيئاً وتلقّاها المختصون بالقبول، وأصبح الإرشاد النفسي يمارس في ضوئها، في حين رفضهاديا

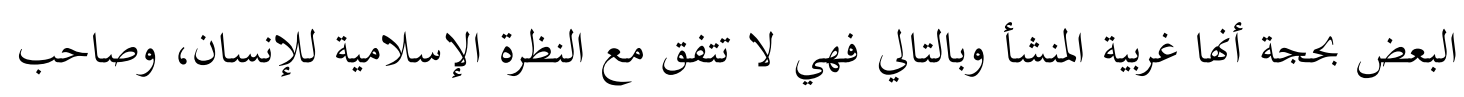
ذلك الدعوات المختلفة من العلماء المسلمين لتأصيل علم النفس والإرشاد النفسي وقضاياهما المختلفة تأصيلاً إسلامياً ونقد هذه النظريات في ضوء المناء المهنج الإسلامي. ولعل من أبرز النظريات وأكثرها استخداماً اليوم في العالم العربي والإسلامي نظرية الإرشاد

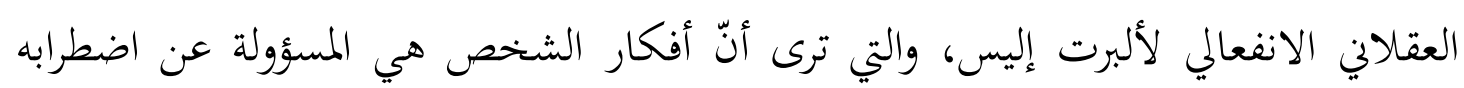
وأنّ كيفية النظر إلى الأحداث هي من تَسِم السلوك بالاضطراب من عدمه. ولعل السبب الذي ساعد في انتشار هذه النظرية يعود إلى سهولة ممارستها ووضوح إجراءاقا، إضافة إلى كوغا أعطت للإنسان اعتباره فلم تصفه بالشر والعدوانية. 
ومن هنا فإنّ الباحث رغب في عرض هذه النظرية على ميزان النقد في ضوء المنهج

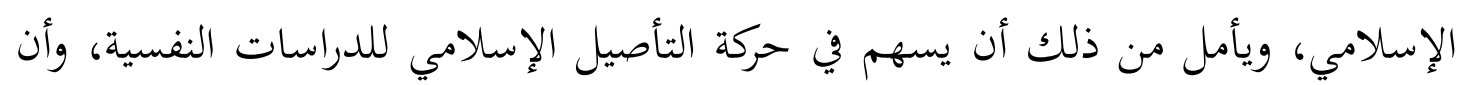
يقدّم للمرشد المسلم نقداً علمياً لهذه النظرية تساعده على فهمها في ضوء المنهج الإسلامي.

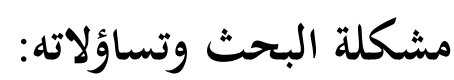

تتعدّد نظريات الإرشاد النفسي وتتباين فيما بينها، وأصبحت تُقدّم في مراكز الإرشاد والعلاج النفسي، ويسعى الباحثون إلى اختبار فاعلية البرامج الإرشادية المستندة على تلك النظريات

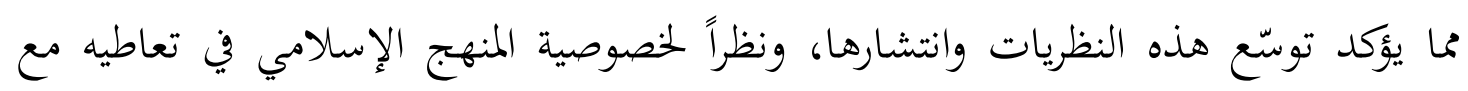

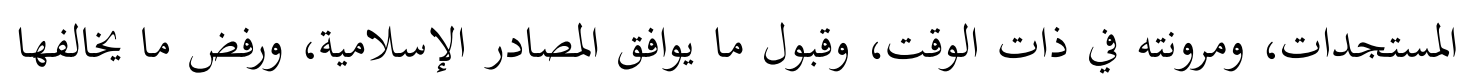

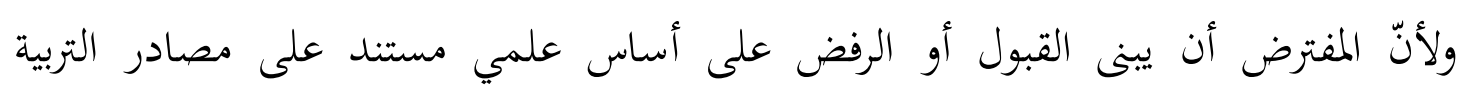

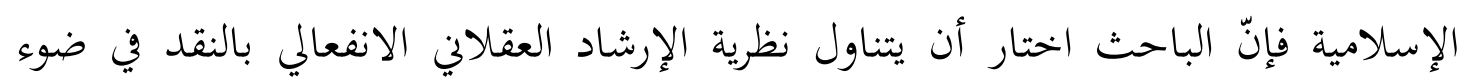

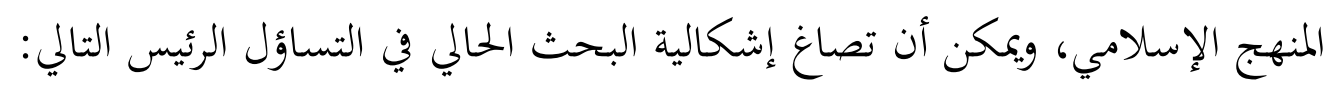
ما النقد الموجّه إلى نظرية الإرشاد العقلاني الانفعالي في ضوء المنهج الإسلامي؟. ويتغرع عنه الأسئلة الفرعية التالية: 1- ما هي نظرية الإرشاد العقلاني الانفعالي؟ وكيف تنظر إلى الإنسان؟ وكيف يحدث الاضطراب النفسي في ضوئها؟ وما أساليب الإرشاد في ضوئها؟ وما إيجابيات هذه النظرية

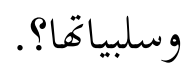

ץ- ما النقد الموجّه إلى نظرية الإرشاد العقلاني الانفعالي في نظرتا إلى الإنسان في ضوء

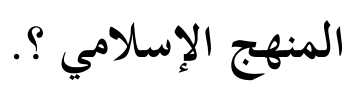
ب- ما النقد الموجّه إلى نظرية الإششاد العقلاني الانفعالي في كيفية حدوث الاضطراب النفسي في ضوء المنهج الإسلامي ؟. ع - ما النقد الموجّه إلى نظرية الإرشاد العقلائ الانفعالي في أساليب الإرشاد في ضوء

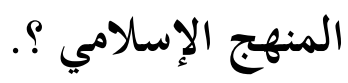

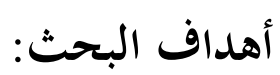
بالنظر إلى مشكلة البحث وتساؤلاته فإنّ البحث يهدف إلى إلى: 
نقد نظرية الإرشاد العقلاني الانفعالي في ضوء المنهج الإسلامي في الجزئيات التالية: النظرة إلى

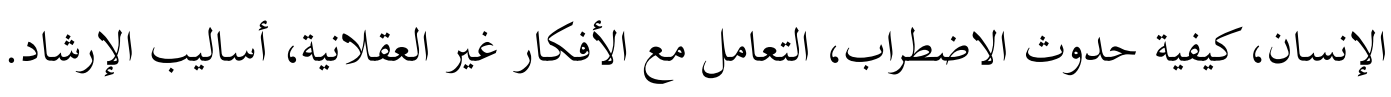

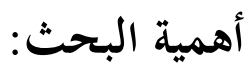
إنّ تناول نظرية الإرشاد العقلاني الانفعالي في ضوء المنهج الإسلامي يكتسب أهميته من

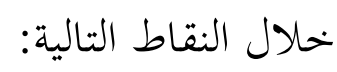
أولاً: أهمية نظرية الإرشاد العقلاني الانفعالي في ذاتما وكوخا من أكثر النظريات انتشاراً في

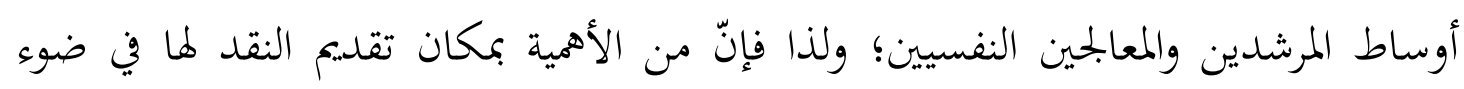

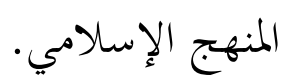

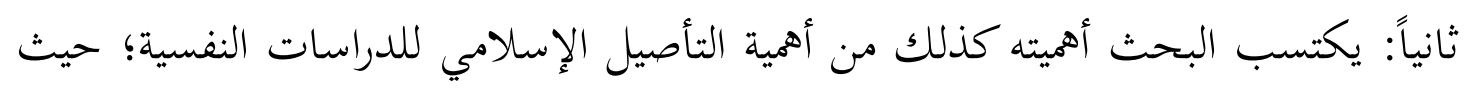

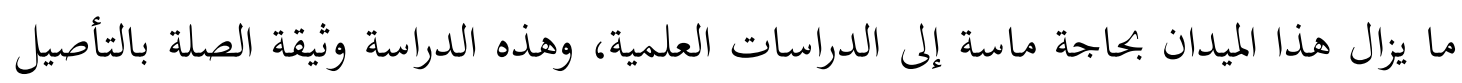
الإسلامي حيث تبحث في نقد إحدى نظريات الإرشاد النفسي وتؤصل لها.

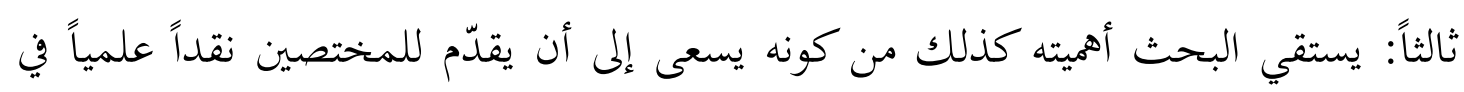

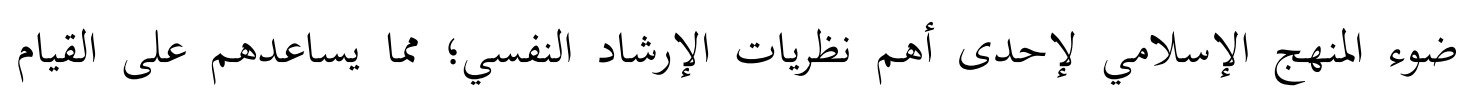
بأعمالهم وانطالاقهم من منطلق إسلامي.

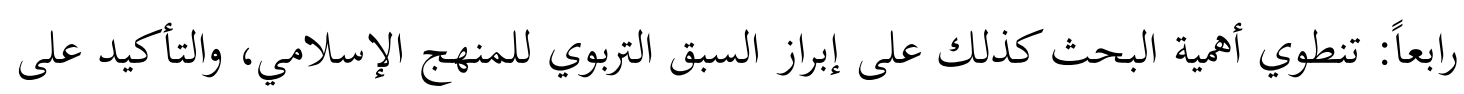

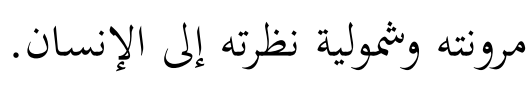

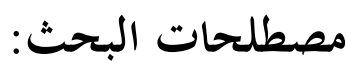
النظرية هي: فكرة عقلية منظمّة تشير إلى مبدأ أو بحموعة من المبادئ التي تحاول تفسير

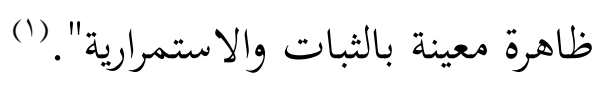
والنظرية في بحال الإرشاد النفسي : "خلاصة جهد الباحثين في بحال الإرشاد والعلاج النفسي، والتي تمكّن المرشد من تفسير الظواهر النفسية من حيث النظرة إلى طبيعة الإنسان:

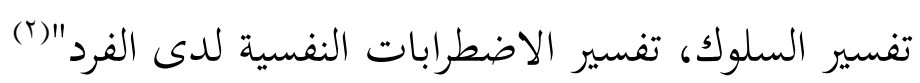

(1) الحارثي، صبحي. (T/ (T). نظريات التوجيه والإرشاد النفسي وتطبيقاتها في الإرشاد المدرسي. الدمام:

$$
\text { مكتبة المتنبي ، صاريق (1) (1). }
$$


ويعرفها بلان بأها:"بحموعة الفرضيات أو المفاهيم المنظمة في نسق فكري يكشف العلاقة

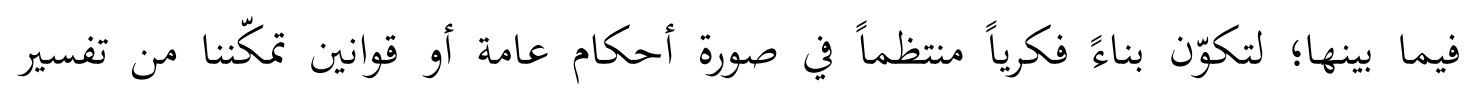
الظواهر أو التبؤ "(1) ويعرّها زهران:"إطار عام يضم مجموعة متناسقة متكاملة من الحقائق والقوانين التي تفسر

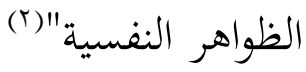
ويُقصد بنظرية الإرشاد العقلائ الانفعالي: هي النظرية التي أسسها ألبرت إليس وهي نظرية

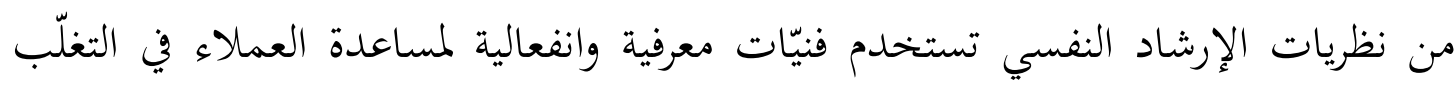
على ما لديهم من أفكار ومعتقدات خاطئة وغير عقلانية، والتي يصاحبها اضطراب في

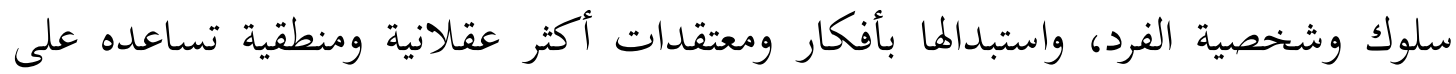
التوافق مع البحتمع. (ب) المنهج الإسلامي: يُقصد به في هذا البحث: المنهج المبني على ما ورد في مصادر التربية الإسلامية من الكتاب والسنة وكتابات العلماء المسلمين، في كيفية النظرة إلى الإنسان، وكيفية حدوث الاضطراب، والتعامل مع الأفكار غير العقلانية، وأساليب الإرشاد.

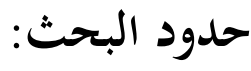

يتحدّد البحث موضوعياً في نقد نظرية الإرشاد العقلاني الانفعالي لإليس دون غيرها من

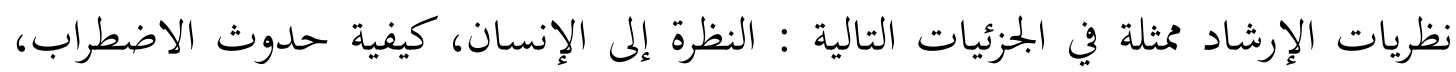
أساليب الإرشاد في ضوء نظرية الإرشاد العقلائ الانفعالي. الدراسات السابقة : الابل

بعد الرجوع إلى قواعد المعلومات، وفهارس الجحامعات، لم يعثر الباحث على أي دراسة تناولت نقد نظرية الإرشاد العقلاني الانفعالي في ضوء المنهج الإسلامي، وأكثر الدراسات

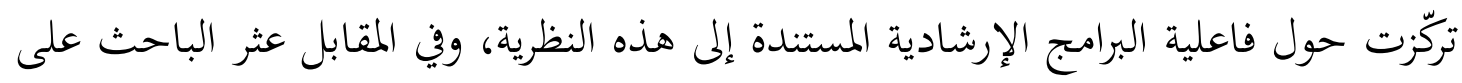
بحموعة دراسات تناولت نظرية (إليس) بالعرض فقط دون نقد، في حين توجد دراسات

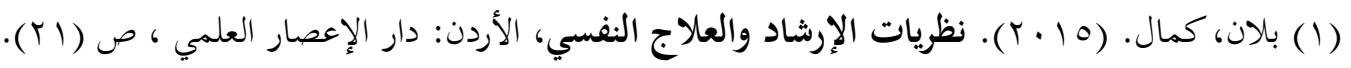

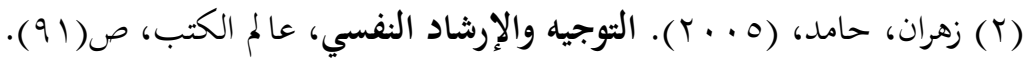

( $\ulcorner$ ) Albert Ellis: The theory of rational guidance, Albert Ellis Institute (AEI). 
أخرى تناولت التأصيل الإسلامي للإرشاد النفسي عموماً، أو بعض جوانب؛ ولذا فإنّّ الباحث يقسّم الدراسات السابقة إلى قسمين : القسم الأول: دراسات تناولت نظرية الإرشاد العقلاني الانفعالي:

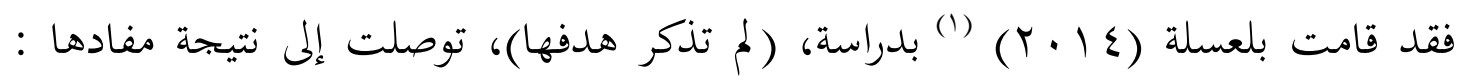

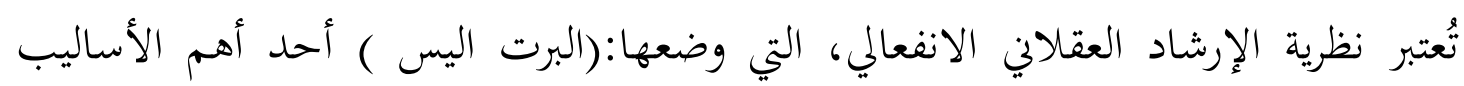

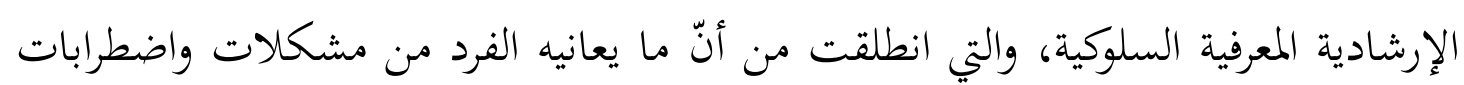

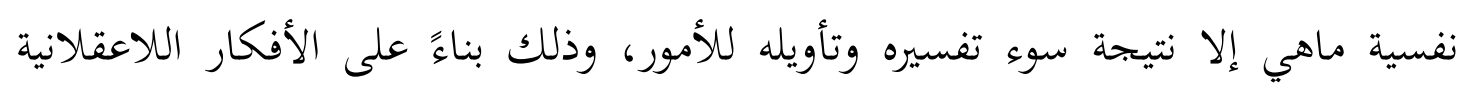

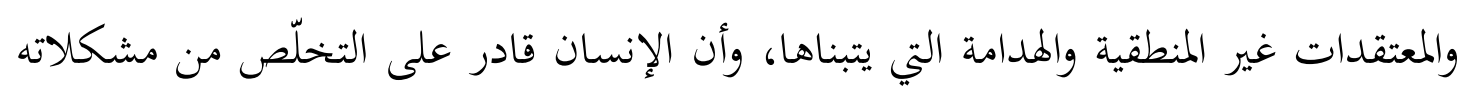

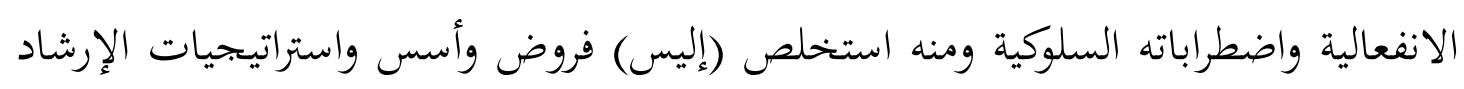

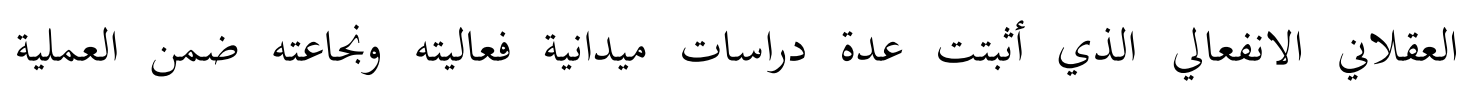
الإرشادية.

وهدفت دراسة ضيف (10 (Y) ()) إلى الوقوف على مسلمات ومفاهيم نظرية الإرشاد

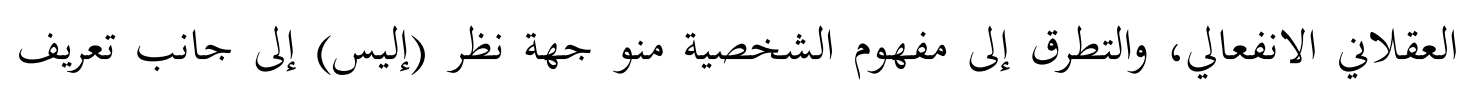

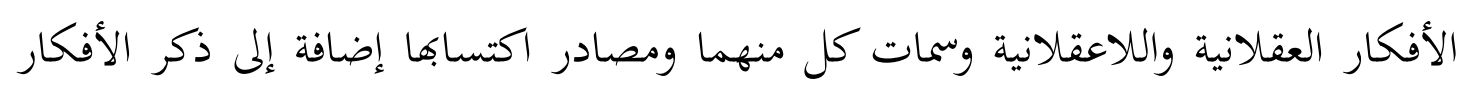

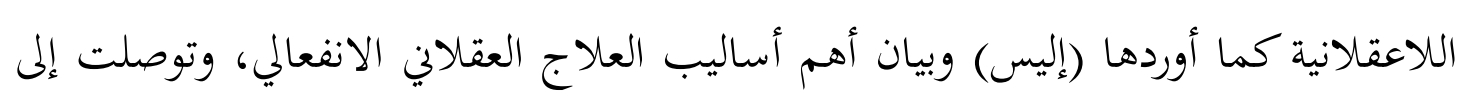

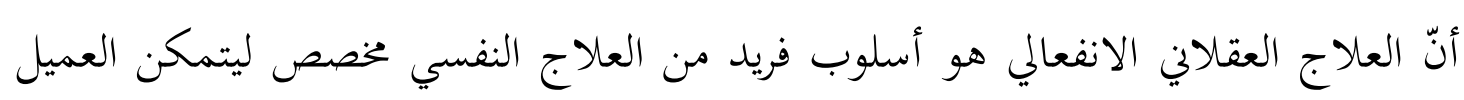

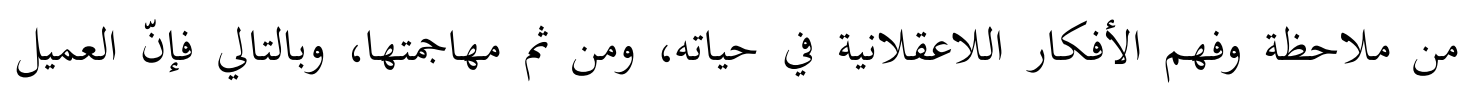

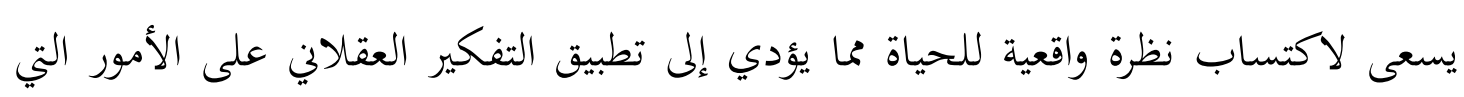

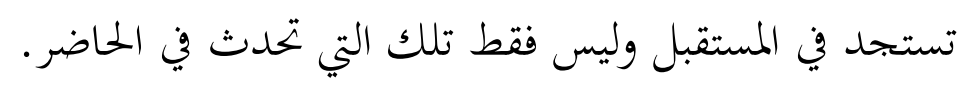

(1) بلعسلة، فتحية. (ع ا · ( ). الارشاد العقلاني الانفعالي لـ أليس : مبادئه ، أسسه وتطبيقاته في العملية

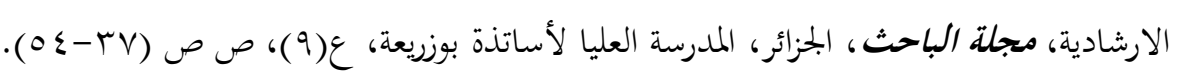

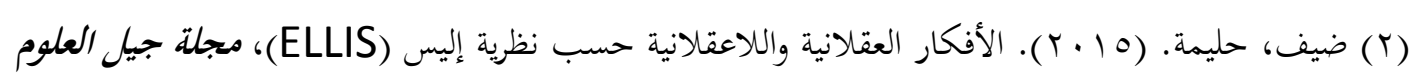

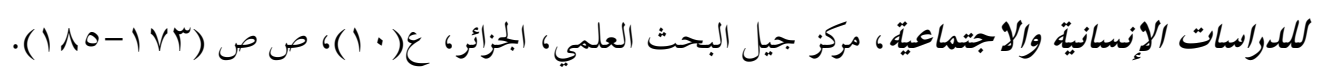




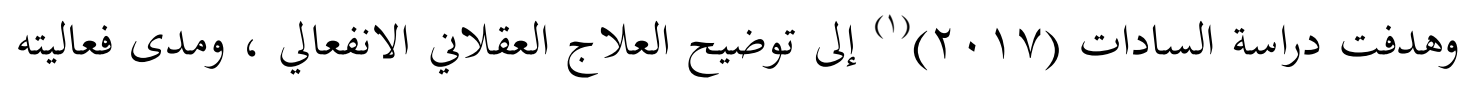
في العملية الارشادية، حيث يستعرض فيها الدارس نظرية الاضطراب التي تنتمي في إطارها

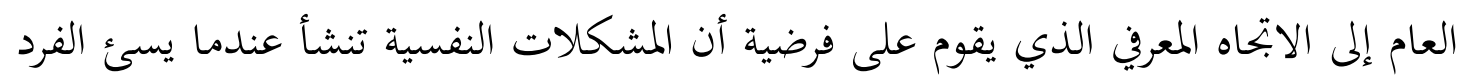

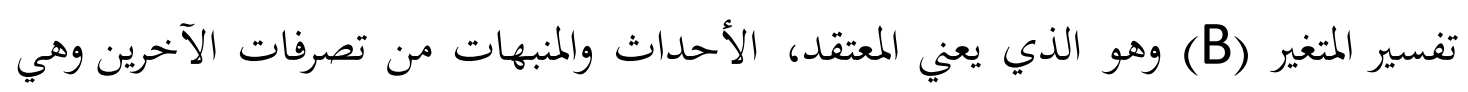

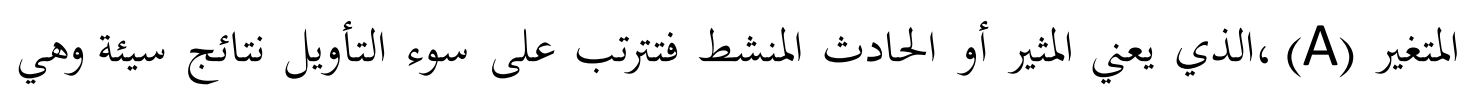
المتغير (C) الذي يعني العاقبة أو النتيجة.

وتوصلت الدراسة إلى نتيجة مؤداها : أنّ النتائج الإيجابية للعلاج المعرفي السلوكي لا تعني

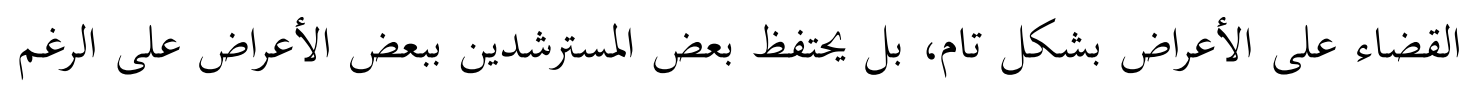

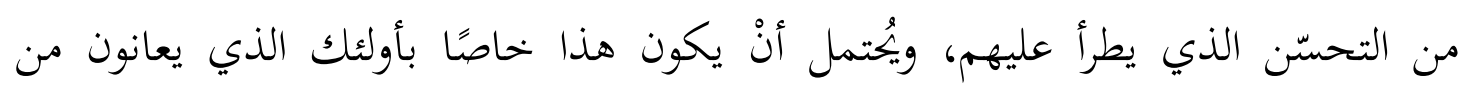

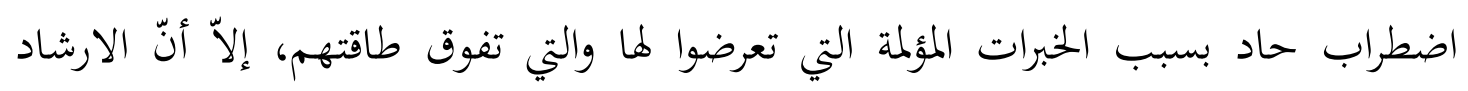
النفسي يساهم قدر المستطاع في التقليل من آثارها ويسمح للمسترشدين أن يصححوا أفكارهم اللاعقلانية بأفكار عقلانية بعد تغيير معتقداتم. القسم الثاني: الدراسات التي تناولت التأصيل الإسلامي للإرشاد النفسي عموماً:

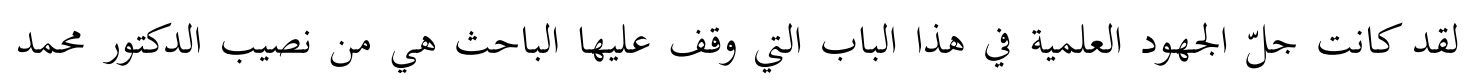

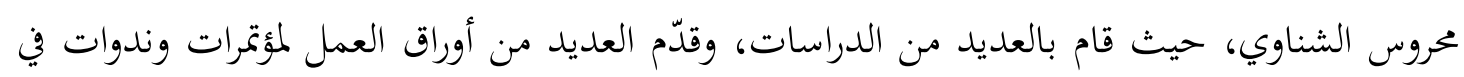

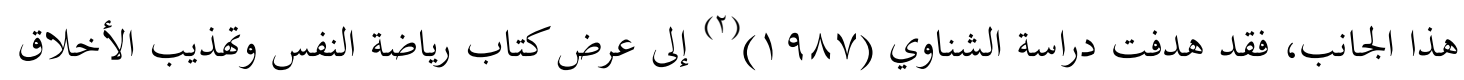

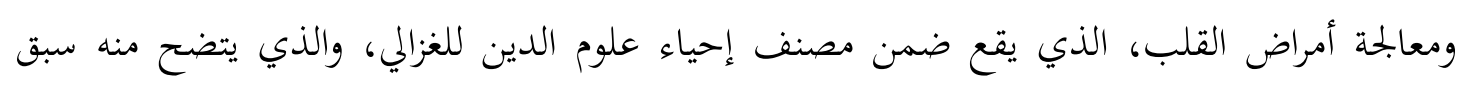

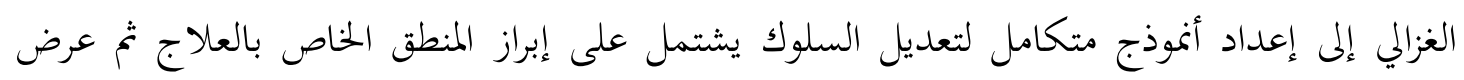

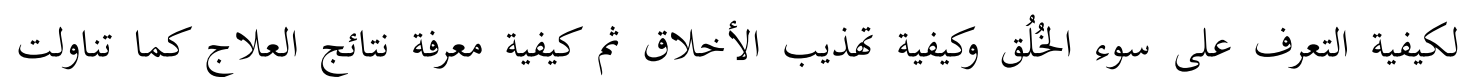

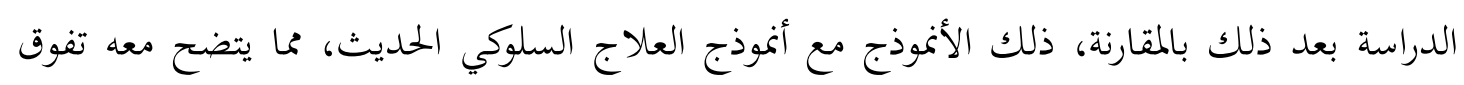

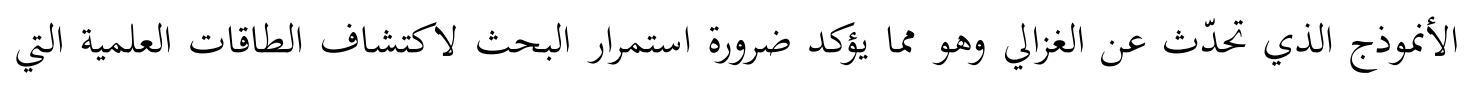
يزخر بها التراث الإسلامي وبصفة خاصة في بحال العلوم الإنسانية.

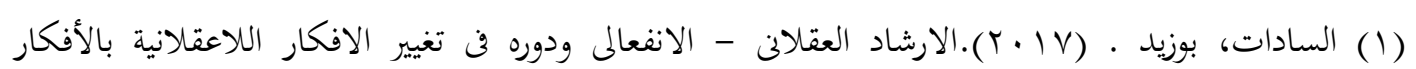

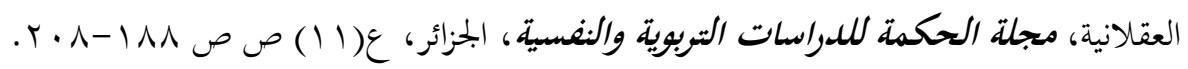

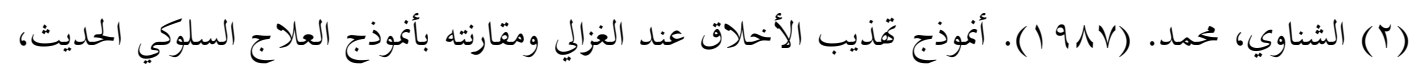

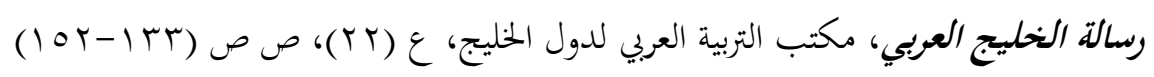


وقدّم الشناوي (919 1) (1) ورقة عمل هدفت إلى إعداد تصوّر مبسط لعمل المرشد المسلم على ضوء

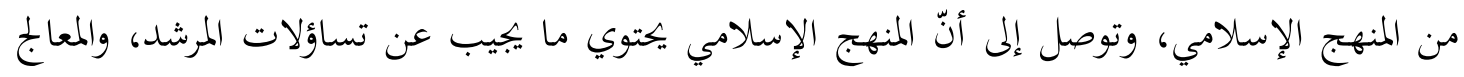

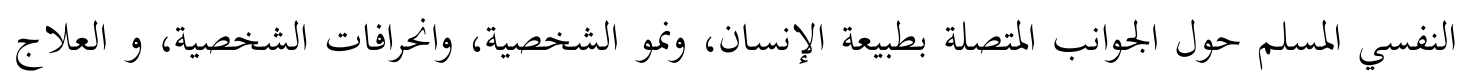
النفسي، وأهداف الإرشاد، ودور المرشد.

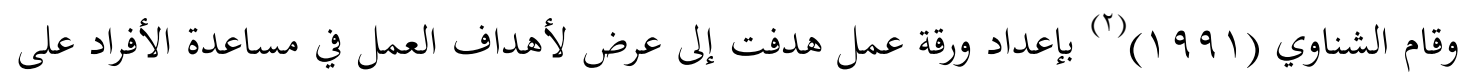

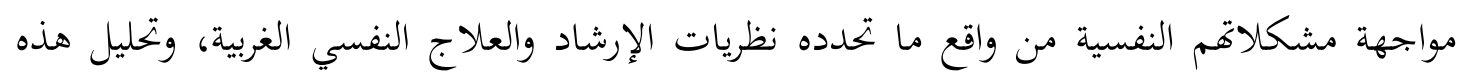

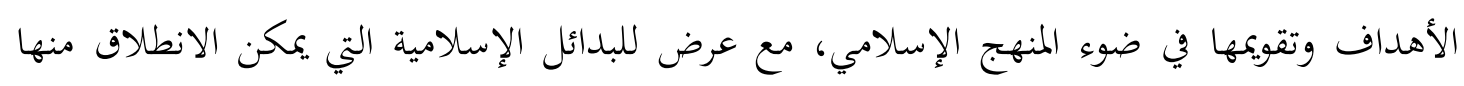

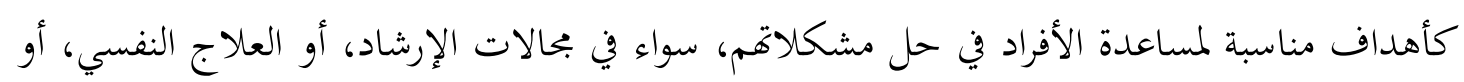

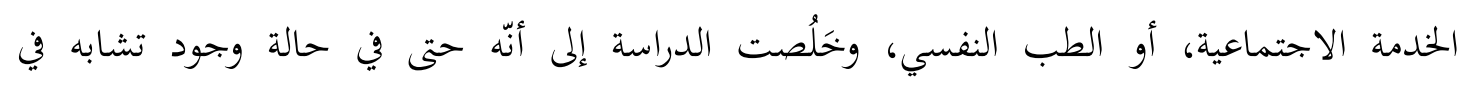

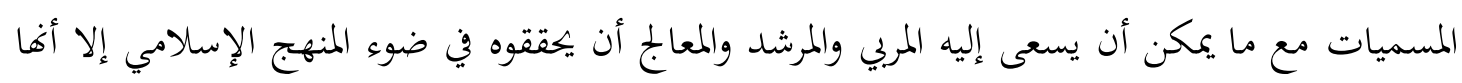

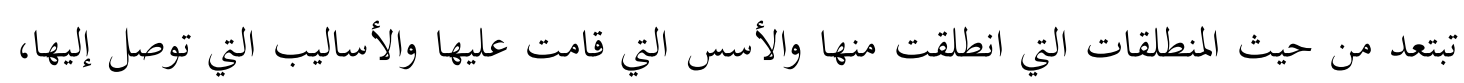

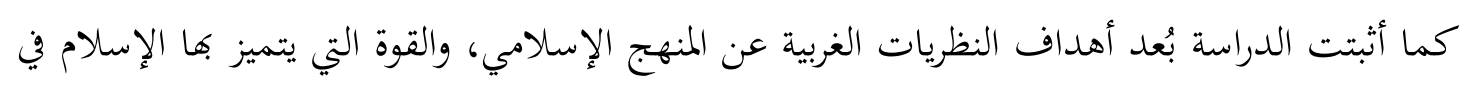
جانب أهداف الإرشاد.

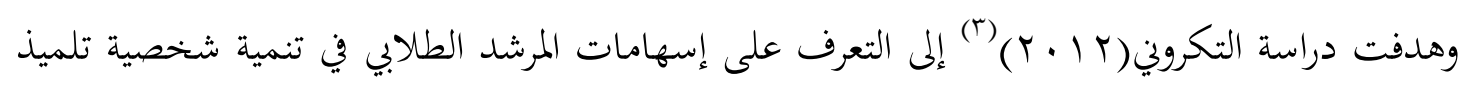

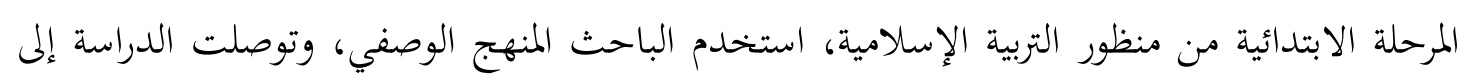

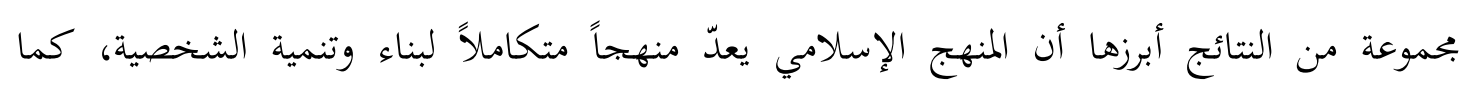

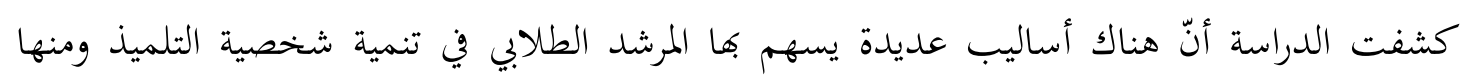
أسلوب القدوة الصالحة والموعظة الحسنة والحوار والإقناع وضرب الأمثال.

(1) الشناوي، محمد. (919 1 ). الإرشاد والعلاج النفسي من منظور إسلامي، ندوة نحو علم نغس إسلامي،

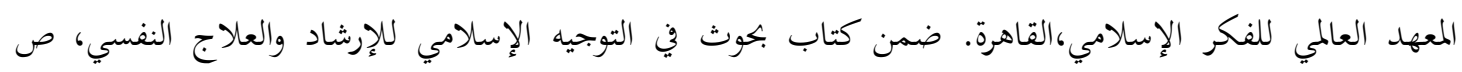
$(Y 0 .-Y \cdot 1)$

(Y) الشناوي، محمد. (Y191) (199). الأهداف العامة لمساعدة الأفراد على مواجهة مشكلاقم النفسية كما تعرضها

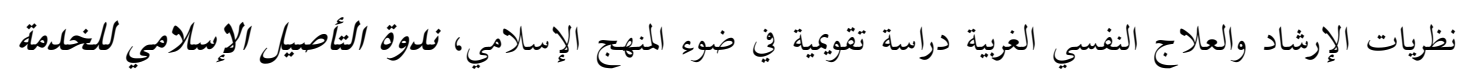

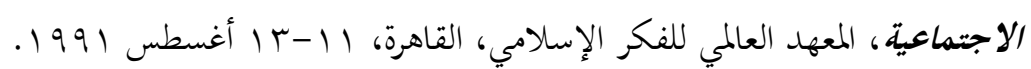

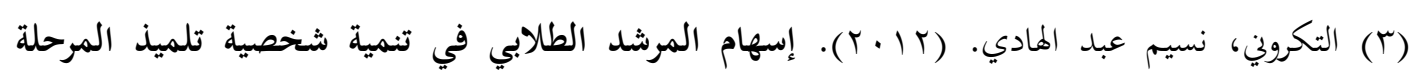
الابتدائية من منظور التربية الإسلامية، رسالة ماجستير غير منشورة، كلية التربية،جامعة أم القرى. 


\section{التعليق على الدراسات السابقة :}

من خلال العرض السابق يظهر بوضوح تشابه البحث الحالي مع الدراسات السابقة في تناول نظرية

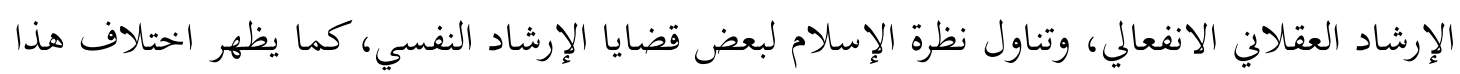

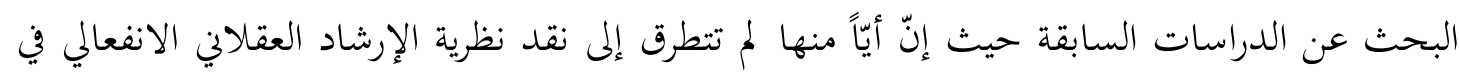

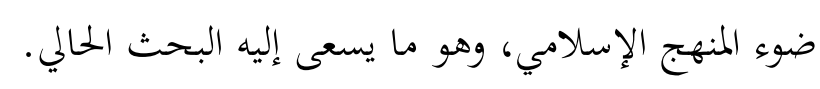

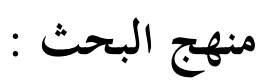

استناداً إلى هدف البحث الحالي فإنّ الباحث استخدم المنهجين التاليين :

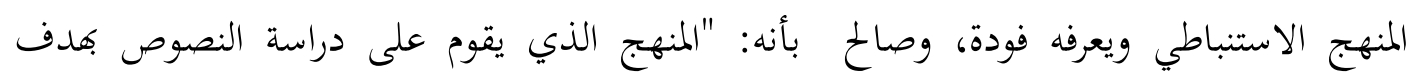

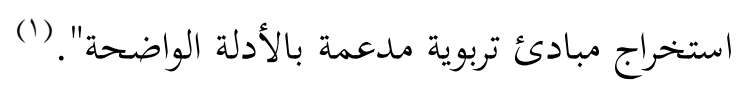

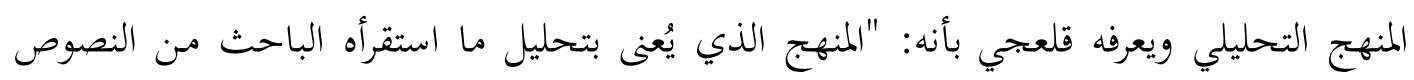

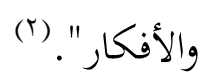

ويستخدم هذان المنهجان لدراسة ما يتحصل عليه الباحث من نصوص حول نقد جزئيات نظرية

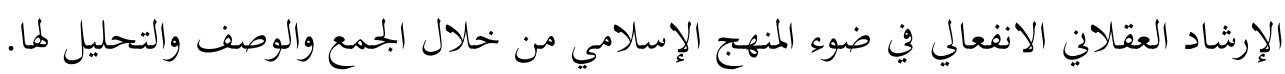

(1) فودة، حلمي، وصالح، عبد الرمن. (911) (1). المرشد في كتابة البحوث التربوية. بيروت: دار العلم للملايين، ص(T/؟). (T) قلعجي، محمد رواس. (799 (199). طرق البحث في الدراسات الإسلامية. بيروت: دار النفائس، ص (9 (1). 


\section{المبحث الأول : عرض نظرية الإرشاد العقلاني الانفعالي:(1)} ترجمة (ألبرت إليس) مؤسس نظرية الإرشاد العقلاني الانفعالي:

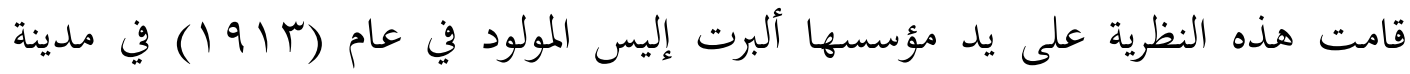

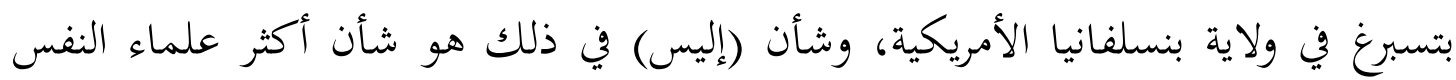
ممن أسسوا نظرياتم في العلاج والإرشاد النفسي، فقد تأثر (إليس) بالأزمات التي مرّ بها في تئي حياته، بداية من إهمال أبيه وأمه، واضطراره إلى تحمل المسؤولية وتربية إخوته في سنّ مبكرة،

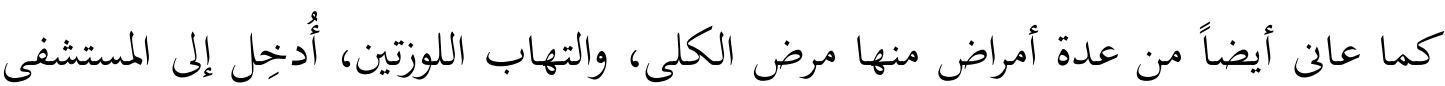

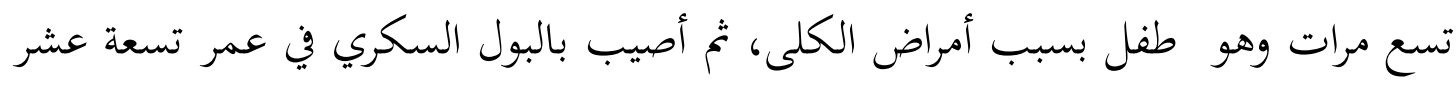
عاماً، وبالسكري وهو في الأربعين من عمره، هذا بالإضافة إلى خحله الزائد في التحدّث

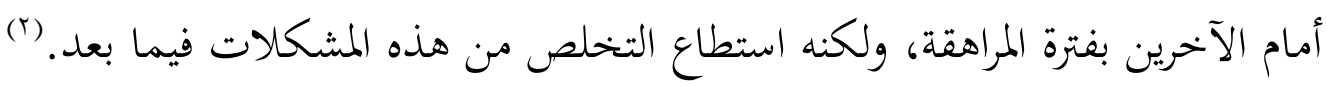

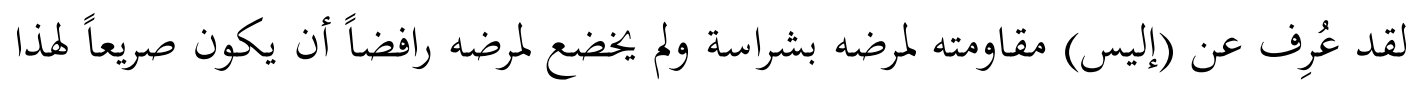

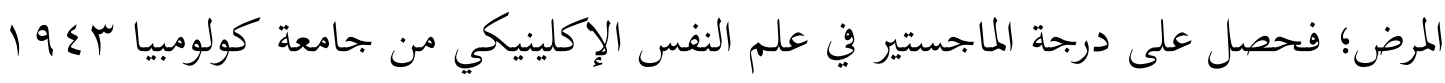
وعلى الدكتوراه عام (Y (9 ( ))، وعاث حياة حيوية ملؤها النشاط والقوة حتى وفاته في عمر ثلاثة وتسعين سنة. (َ)

وفي أثناء بحثه عن حل لمشكلاته ابته إلى مدرسة التحليل النفسي لسيجومند فرويد عندما قرر أن يعمل بالتحليل النفسي، (ء) حيث آمن بأنّ المدرسة التحليلية هي الأعمق قياساً

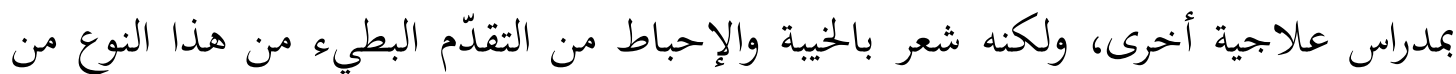

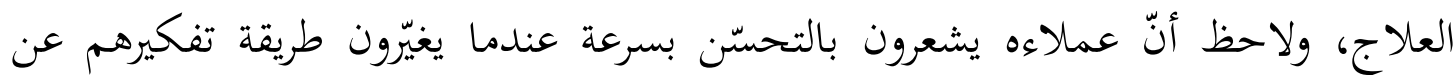

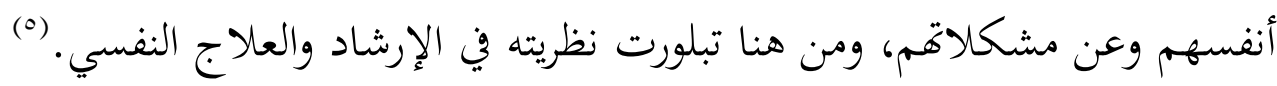

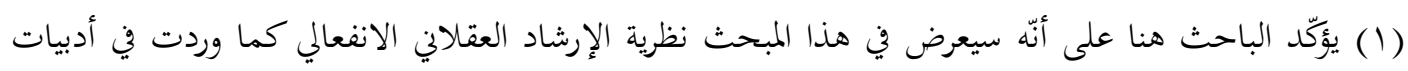

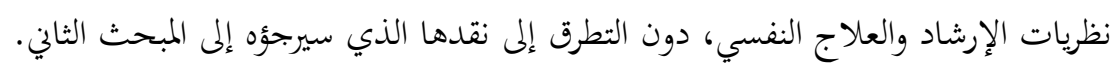

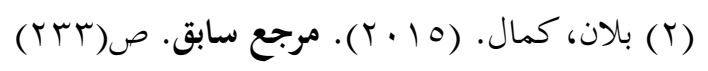

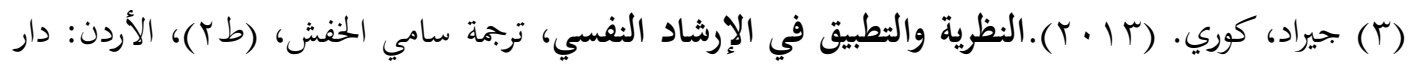

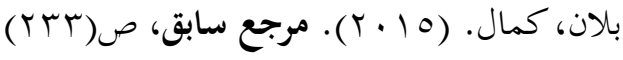

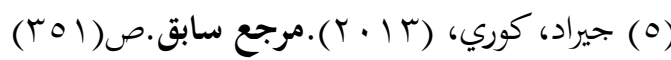


كما يُعدّة (إليس) من أكثر الناشطين في حركة الإرشاد والعلاج النفسي وله أكثر من

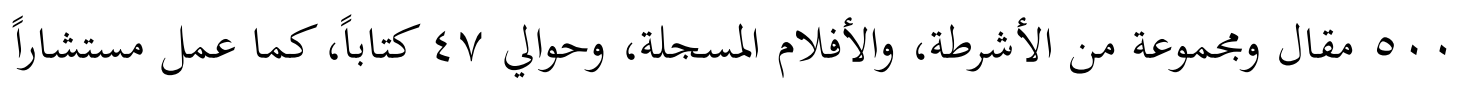

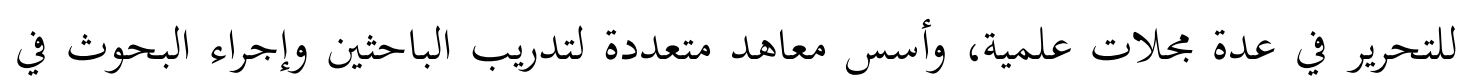
بجال الإرشاد والعلاج العقلاني الانععالي في الولايات المتحدة الأمريكية وكندا واستراليا وغيرها، كما حصل على بحموعة من الجوائز في بحال الدراسات النفسية. (1)

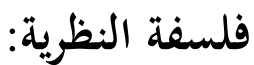

تشير الأدبيات إلى أنّ الفكرة الأساسية لمذه النظرية قديمة جداً فقد تنبّه الفلاسفة

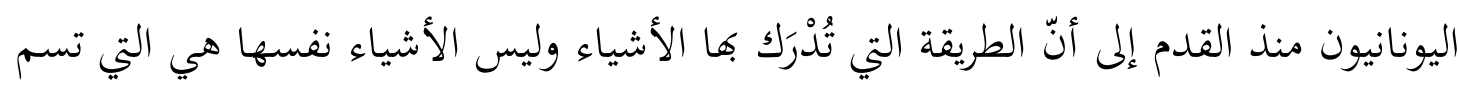

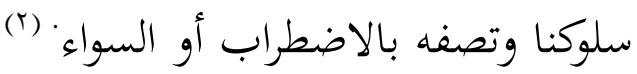

$$
\begin{aligned}
& \text { تعريف الإرشاد العقلاني الانفعالي: }
\end{aligned}
$$

هو نظرية من نظريات الإرشاد النفسي تستخدم فنيات معرفية وانفعالية لمساعدة العملاء في التغلّب على ما لديهم من أفكار ومعتقدات خاطئة وغير عقلانية، والتي يصاحبها اضطراب في سلوك وشخصية الفرد، واستبدالها بأفكار ومعتقدات أكثر عقلانية ومنطقية

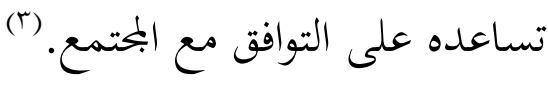

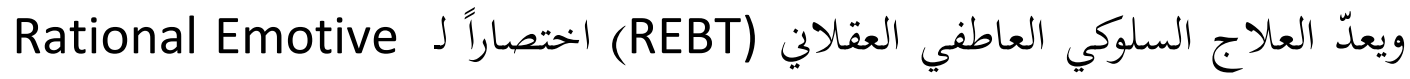
Behavior Therapy

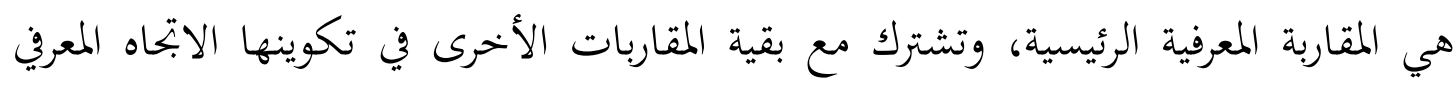

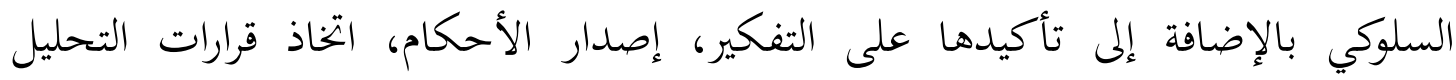
والممارسة العملية.(3)

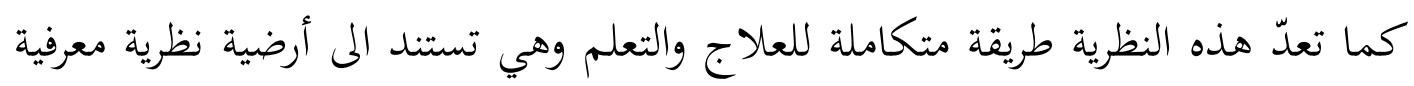

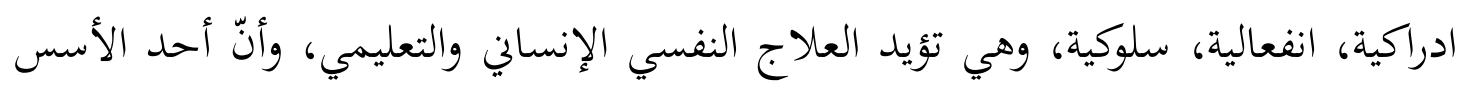

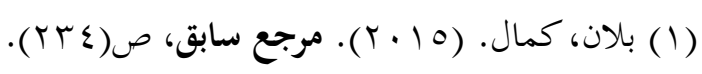

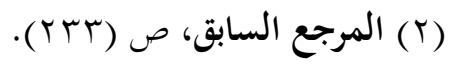

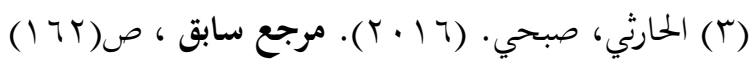

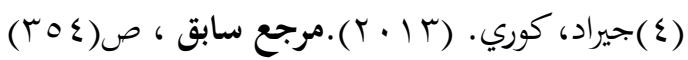


هو أنّ مشاكل الإنسان تنتج من طريقة تفكيره ومعالجته لهذه الأحداث الخارجية ابتداءً من

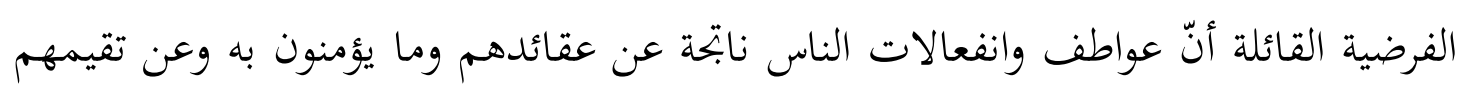

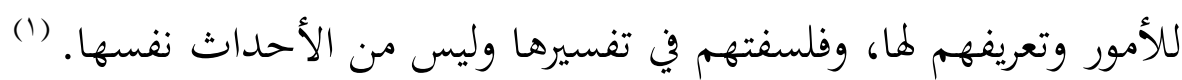

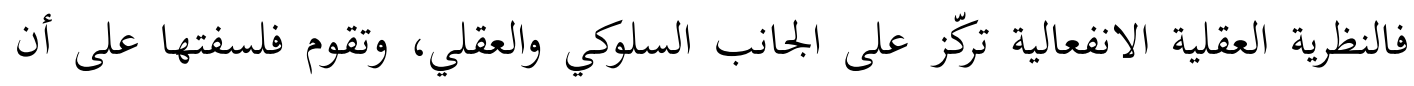

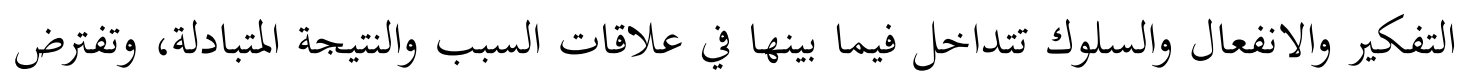

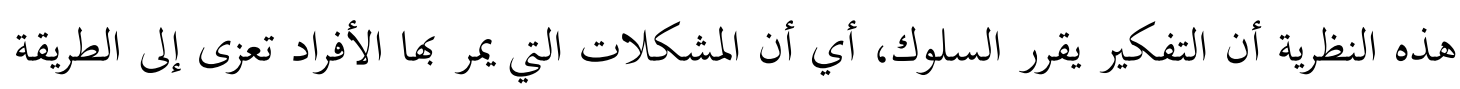

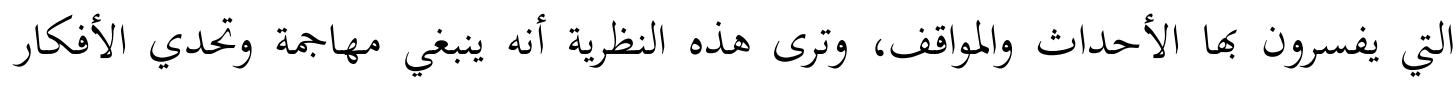

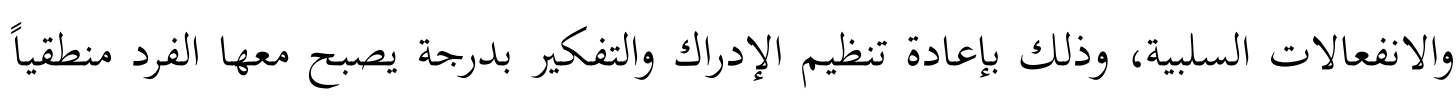

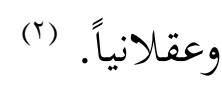

وفي الجملة فقد جاء (إليس) ليكشف أنّ عدم التقدّم في إحراز نتائج طيبة عائد إلى حقيقة أنّ المرضى كانوا يعيدون تأسيس أنفسهم على المبادئ اللاعقلانية التي الخترعوها وتعلموها في طفولتهم. (")

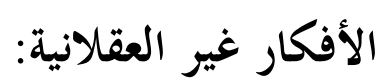

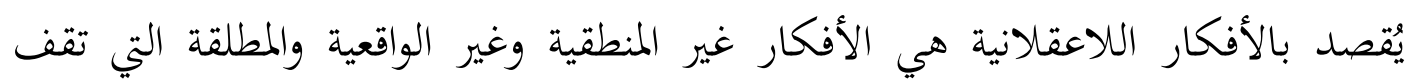

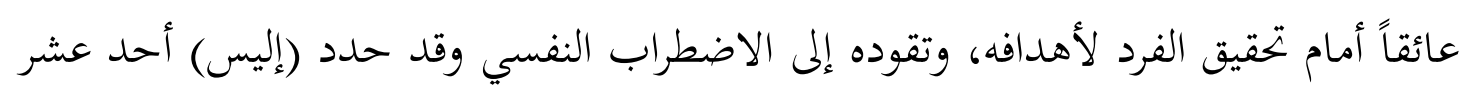

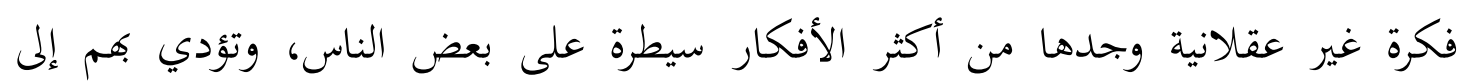
الاضطراب النفسي وهذه الأفكار هي (8):

الفكرة الأولى: طلب الاستحسان: من الضروري أن يكون الشخص محبوباً ومقبولاً

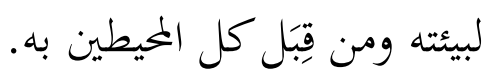

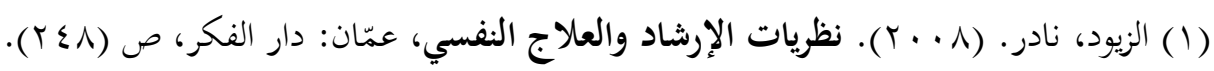

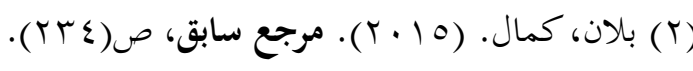

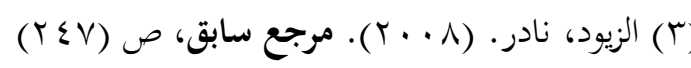

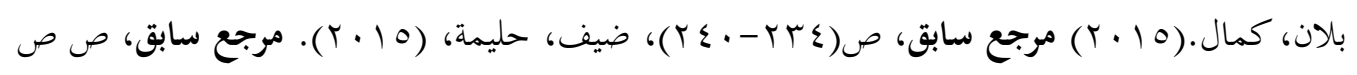


وهذه فكرة غير عقلانية؛ إذ يستحيل أن يكون الشخص محبوباً من جميع المخيطين به،

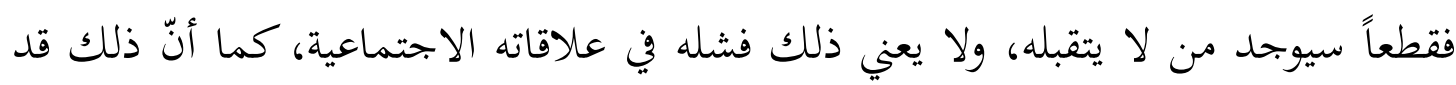

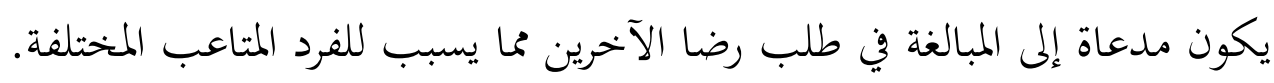

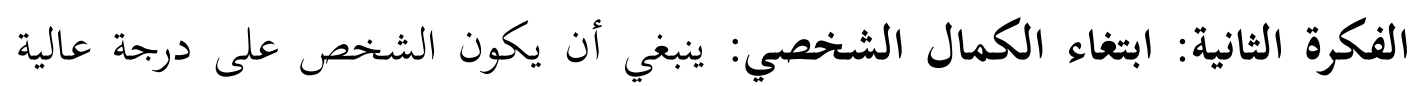

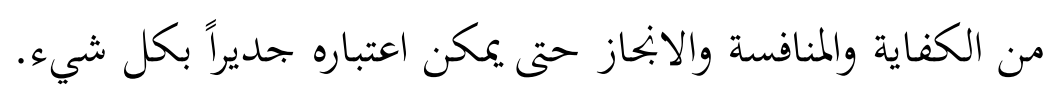

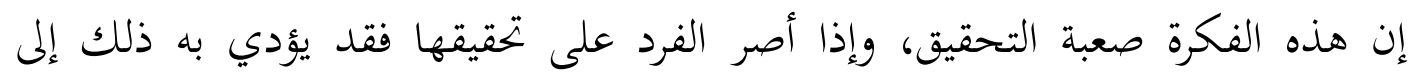

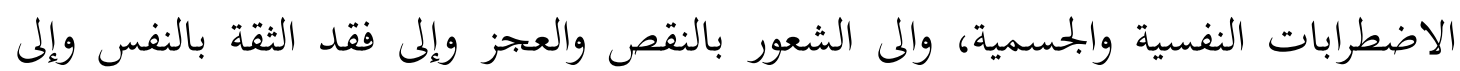

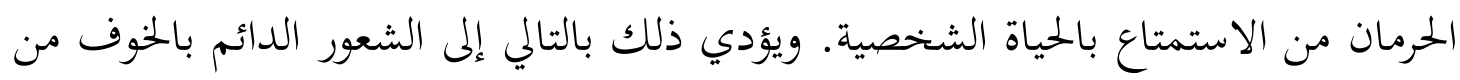

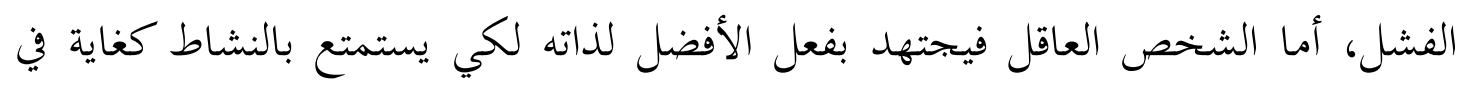
ذاته وليس من أجل ننيجة. (1) الفكرة الثالثة: اللوم القاسي للذات وللآخرين: بعض الناس يتصفون بالشر، والجهُبن ولذلك فهم يستحقون اللوم والتوبيخ والعقاب.

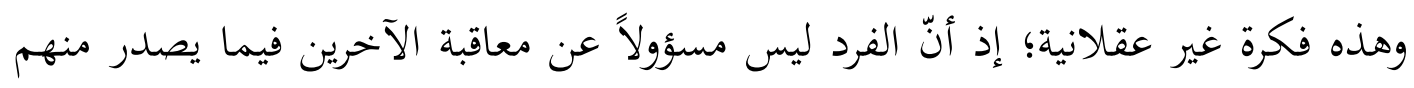

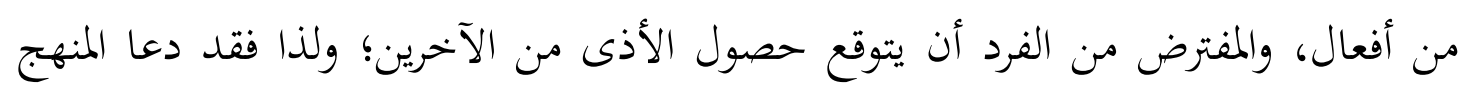
الإسلامي إلى تحمّل الأذى من الآخرين وكفّه عنهم.

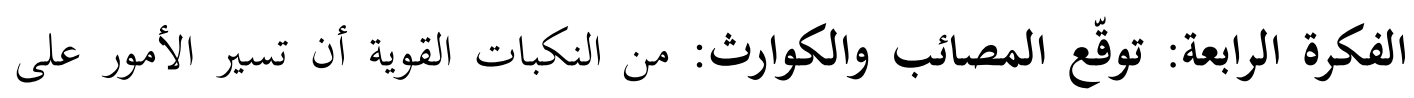
غير ما يريد الفرد لها. وهذه فكرة غير عقلانية؛ إذ أنّ الأمور لن بتري دائماً وفق ما يريد لها الفرد، والمصائب

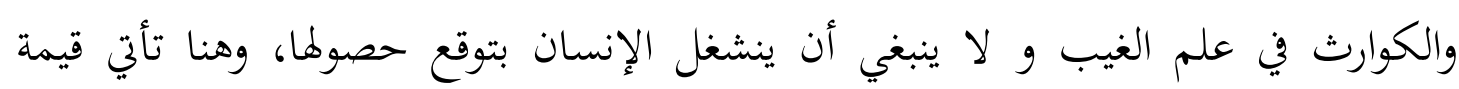

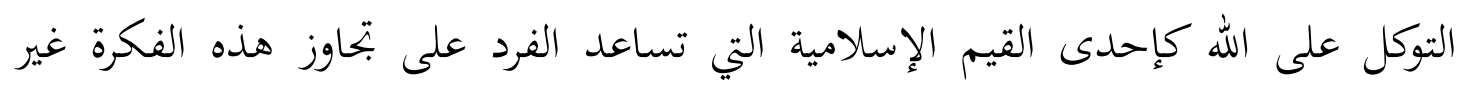
العقلانية.

الفكرة الخامسة: التهور (اللامبالاة الانفعالية): تنتج التعاسة من ظروف خارجية لا نغلك القدرة على التحكم فيها. 
وهذه الفكرة (من وجهة نظر إليس) غير منطقية، فالأشياء الخارجية قد لا تكون مدمرة

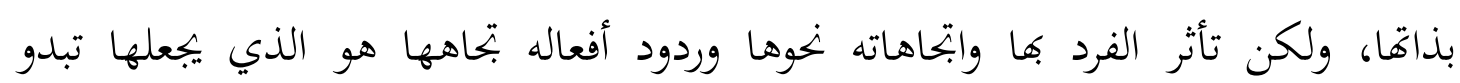
كذلك. والمفترض أن يدرك الفرد أنّ التعاسة تأتي غالباً من داخله، وقد تأتي المضايقة من الخارج،

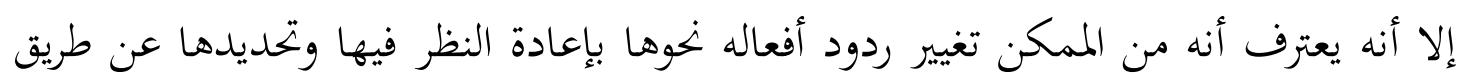
تغيير تصوراته وتعبيراته الداخلية نخوها. (1) الفكرة السادسة: القلق الزائد: الأشياء الخطرة والمخيفة تعتبر سبباً للانشغال الدائم للفكر، وينبغي أن يتوقعها الفرد دائماً وأن يستعد لمواجهتها.

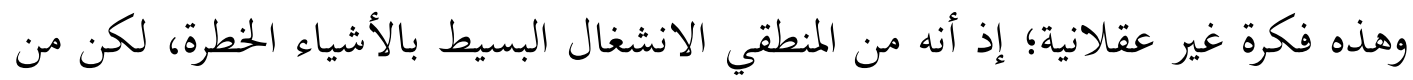

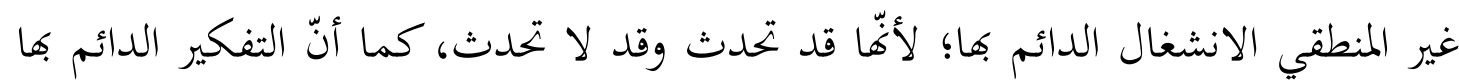
لن يمنع من وقوعها. الفكرة السابعة: تجنّب المشكلات: الأسهل بتنب الصعوبات والمسؤوليات الشخصية عن أن تواجهها. وهذه غير فكرة غير عقلانية، إذ أنّ حل الصعوبات يكون بمواجهتها وليس بتحنبّها، كما

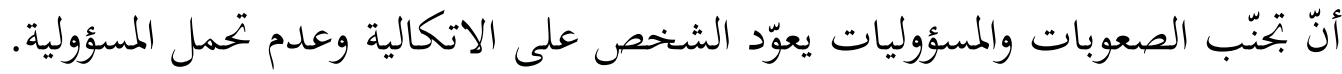
الفكرة الثامنة: الاعتمادية: يجب أن يعتمد الإنسان على الآخرين، وأن يكون دائماً إلى الى جانبه شخص أقوى منه، يعتمد عليه. من المنطقي أن يمتاج الإنسان إلى من يعينه في أمور حياته، ولكن ليس من العيه العقلانية أنّ النّان

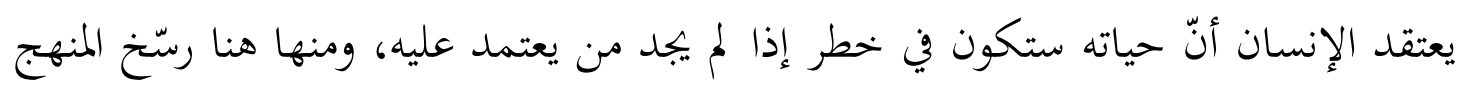
الإسلامي في نفوس أفراده الاعتماد على الحالق سبحانه والتوكل عليه وتفويض الأمر إليه.

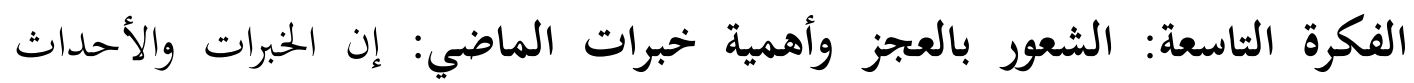
الماضية هي المحددات الأساسية للسلوك الحاضر والمؤثرات الماضية لا يمكن استبعادها. 
وهذه فكرة غير عقلانية؛ إذ لا يمكن أن يكون الشخص حبيس الماضي ويفسد عليه حاضره، فالماضي لن يعود، والمفترض أن يستفيد الشخص من الأحداث الماضية في بتحاوز

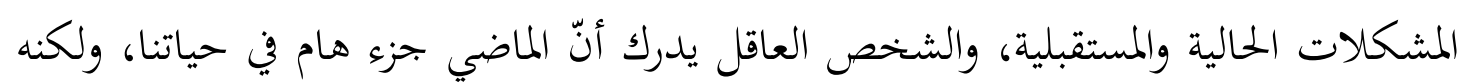

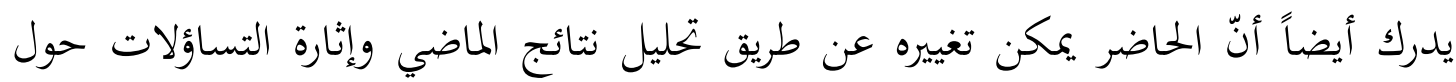
بعض الأفكار المؤلمة المكتسبة التي تضطره إلى التصرف بطريقة عختلفة في الوقت الحالي. (1)

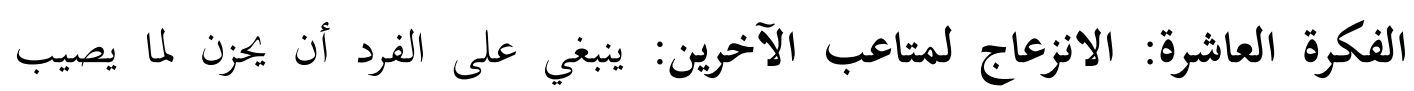
الآخرين من اضطرابات ومشكلات.

وإن كان الباحث لا يوافق على عدم عقلانية هذه الفكرة مطلقاً؛ إذ أنّ المسلم يحب وإنب

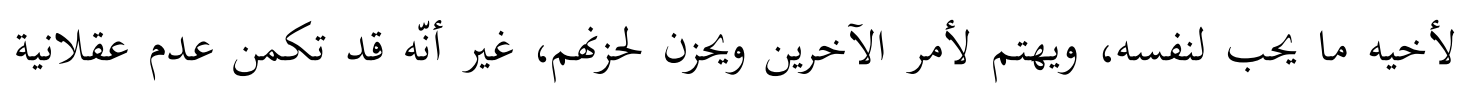
هذه الفكرة في حال أصبح الشخص يهتم بالآخرين أكثر من نفسه إلى درجة لهنمئ إهمال مشكلاته الشخصية.

الفكرة الحادية عشرة: ابتغاء الحلول الكاملة: هناك دائماً حل صحيح أو كامل لكل مشكلة وهذا الحل يجب التوصل إليه، وإلا فإنّ النتائج سوف تكون مؤلمة.

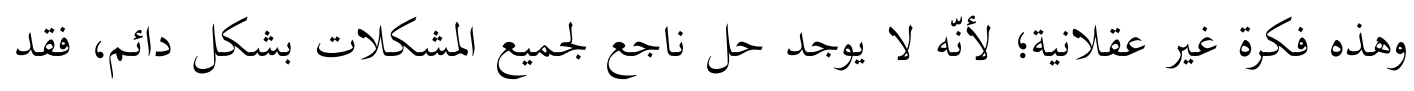

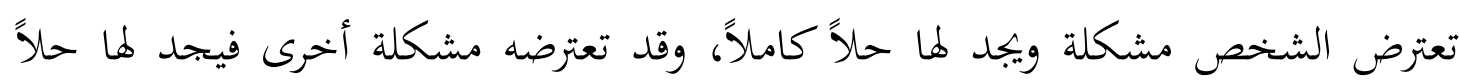

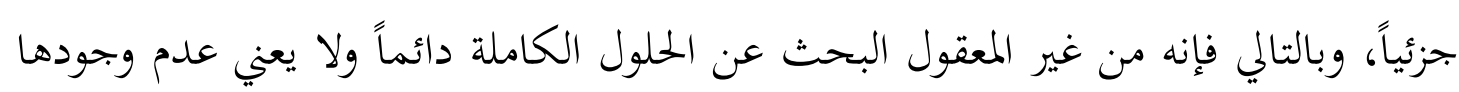
أنّ النتائج ستكون مؤلمة. وقد قسّم (إليس) تلك الأفكار اللاعقلانية إلى ثلاث بحموعات، وقد سمّيّت تلك المحموعات بالحتميات الثلاث، وقد أشار (إليس) في كتاباته إلى أن الأفكار والمعتقدات اللاعقلانية التي يعبر عنها العميل ويعتنقها، تندرج تحت ثلاث حتميات أساسية هي (r) أ-إ-إنمطالب المتعلقة بالذات: هذه المطالب تظهر في عبارات مثل:

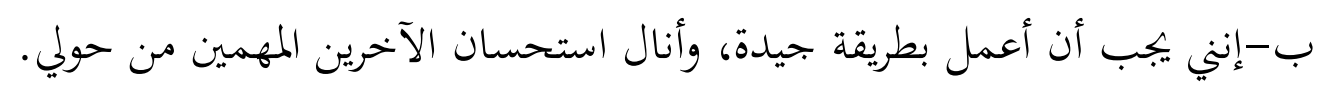

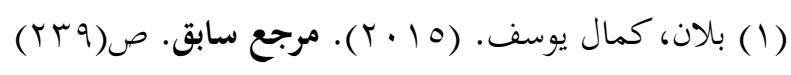

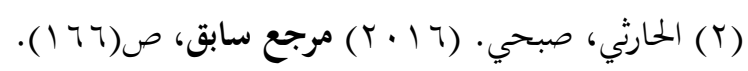


r- المطالب المتعلقة بالآخرين: وتظهر من خلال عبارات مثل:

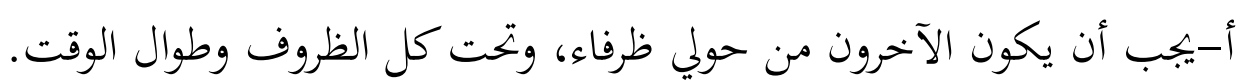
ب-يجب عليك أن تعاملني برفق وبعدل في كل الأحوال. r - المطالب المتعلقة بالعالم وظروف الحياة:

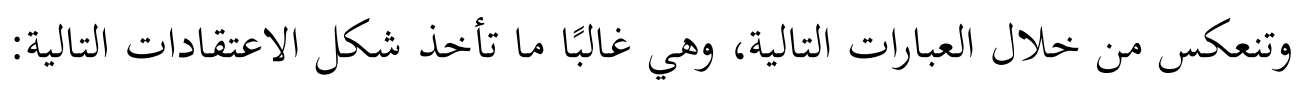

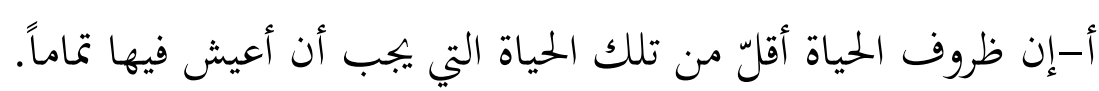
ب- إني لا لأستطيع تحمّل ظروف الحياة.

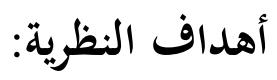

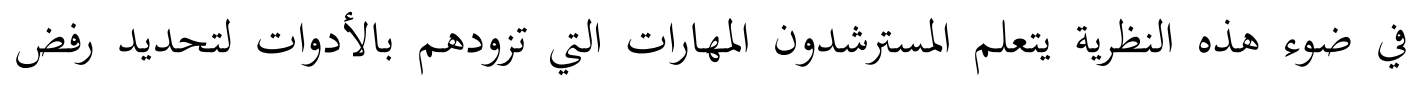

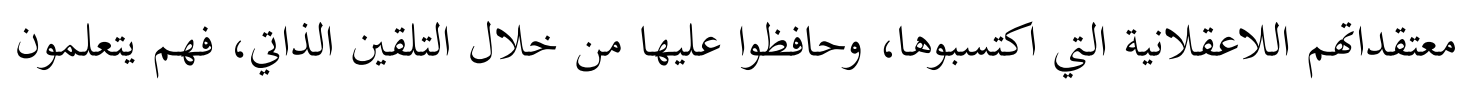

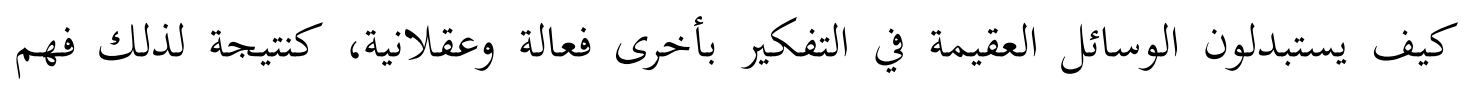

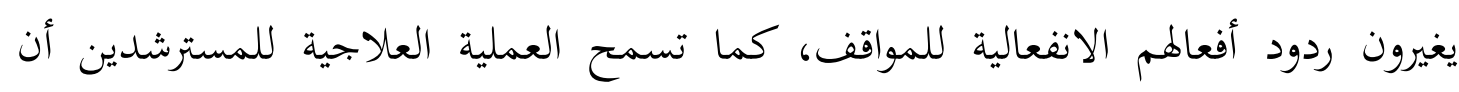

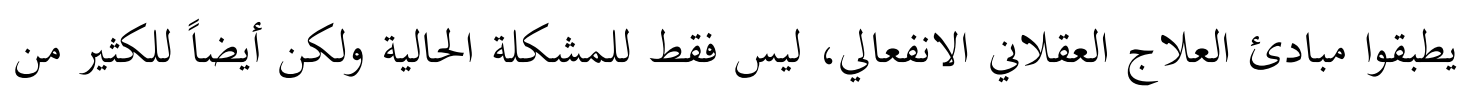

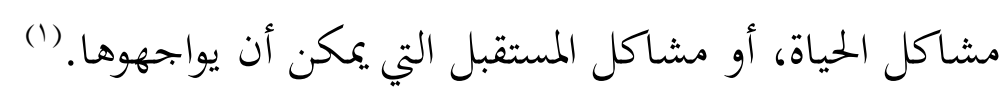

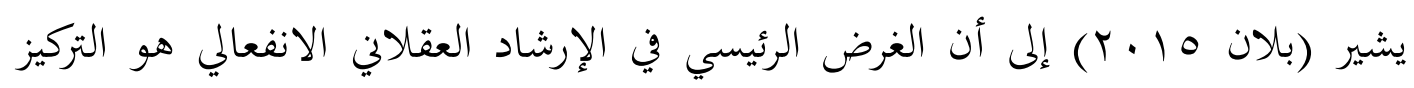

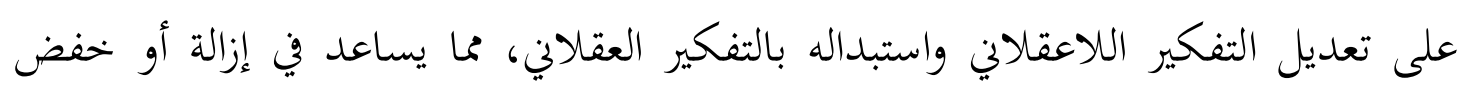

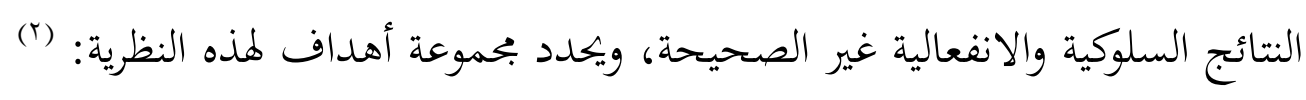
ا ـ خفض الاضطرابات النفسية والانفعالية إلى أقصى حد ميكن.

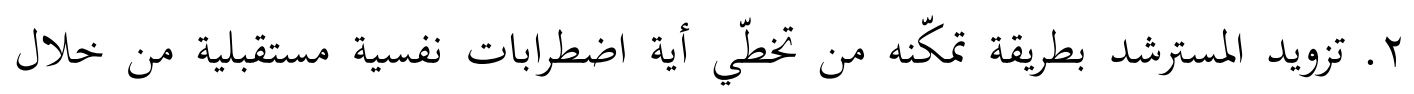
إكسابه فلسفة أكثر عقلانية.

r. استخدام العمليات العقلية وأساليب تعليم التفكير المنطقي خلال عملية الإرشاد.

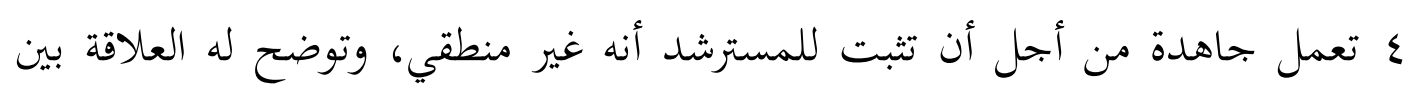

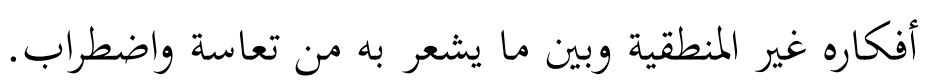

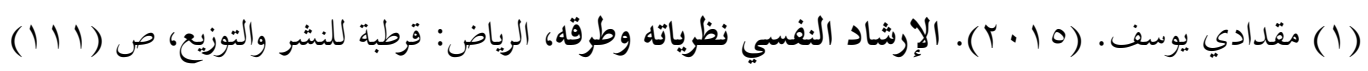

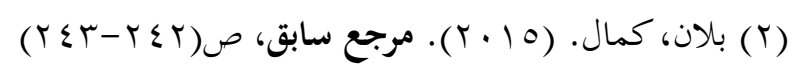


هـ تساعد المسترشد على أن يغيّر تفكيره ويتخلص من الأفكار غير المنطقية وبتعله يعمم وينتقل من بحرد التعامل مع بحموعة الأفكار غير المنطقية إلى الأفكار الأعم والأشمل.

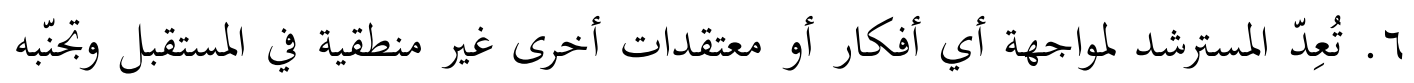
بذلك الوقوع مرة ثانية في الاضطراب.

\section{النظرة إلى الإنسان من وجهة نظر النظرية:}

تؤمن النظرية العقلانية الانفعالية أنّ الإنسان يولد ولديه إمكانية للتفكير العقلاني أو غير

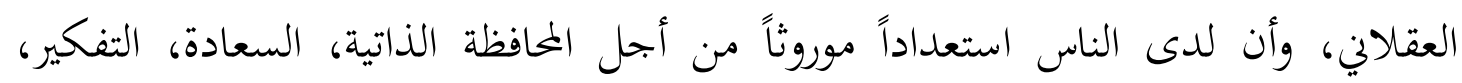
الكلام الحب، الاتصال، المشاركة مع الآخرين، النمو وتحقيق الذات لدى الناسن الناس، وأيضاً النزعة للدمار الذاتي، تجنّب التفكير، التفكير الخرافي، عدم التحمّل، الكمالية، لوم الذات

$$
\text { وبتجب تمقيق إمكانية النمو. (1) }
$$

فالعلاج العقلاني الانفعالي يؤمن ببديهة أن الإنسان غير معصوم عن الخطأ، وأن الناس كمخلوقات سوف تستمر في عمل الأخطاء وبنفس الوقت يتعلمون كيف يعيشون بسلام مع انفسهم. (ז) (1) كما أنّه من الأفكار الأساسية عند (إليس) عن الإنسان أنّ هناك تشابكاً بين العاطفة

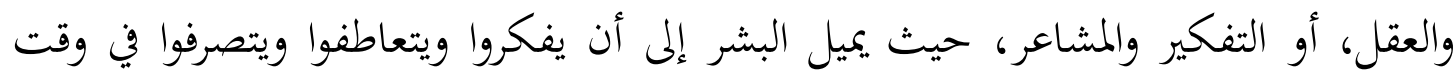

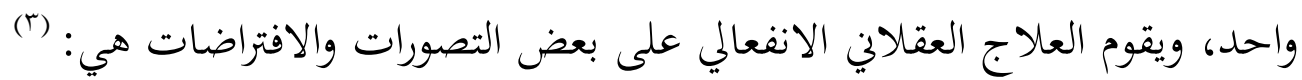
- الإنسان عقلاني ولاعقلاني في آن واحد، وهو عندما يفكر ويتصرف بشكل بعل الان عقلاني

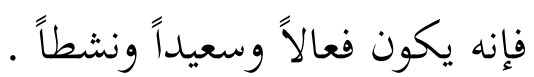
- يميل بعض الأفراد إلى استخدام بعض (الأساليب الدفاعية ضد أفكارهم وسلوكهم؛

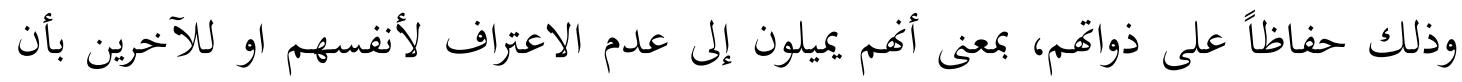
سلوكهم وتفكيرهم خاطئ وأكثر سلبية.

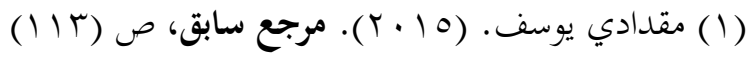

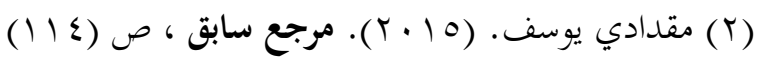

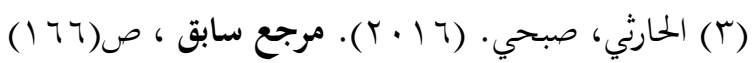


- التفكير غير العقلاني مُتَعلمّم منذ سن مبكرة لدى الطفل من الأسرة، وثقافة البمتمع الذي يعيش فيه.

- التفكير والانفعال يمثلان وجهين لشيء واحد، فلا يمكن النظر إلى أحدهما بمعزل عن

\section{كيف يحدث الاضطراب في ضوء نظرية الإرشاد العقلاني الانفعالي:}

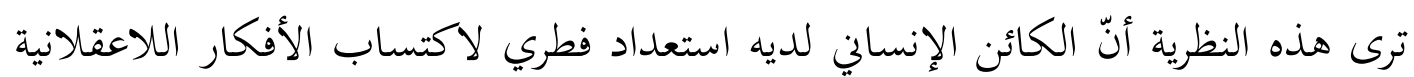

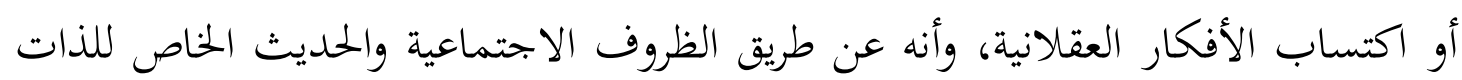

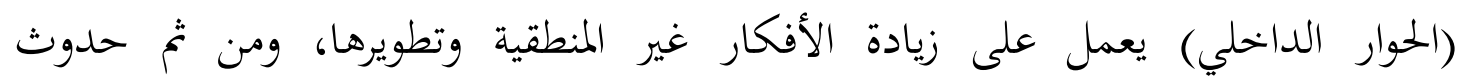
الاضطراب النفسي ولكن لدى الإنسان قدرة فائقة على التفكير بشكل عقلاني وتفادي حدوث الاضطرابات النفسية. (1)

إن الافتراض الأساسي في هذا الاتحاه (المعريف السلوكي) هو أن الناس يسهمون بمشكلاتم النفسية وبأعراض مرضية محددة، من خلال الطريقة التي يفسرون بها الأحداث

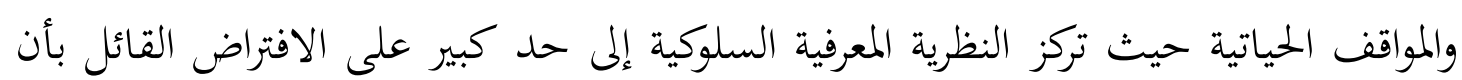

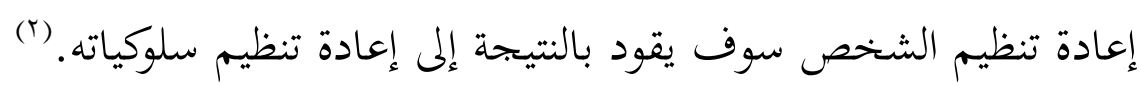
معادلة إليس للاضطراب والعلاج: (ب) قام (إليس) بوضع معادلة تشرح كيفية حدوث الاضطراب سماها (A B C) وأضاف لها (E F D) (Activating event) A (Belief) B (Emotional and Behavioral Consequences) C (Disputing Intervention) D الأفكار أو تفنيدها.

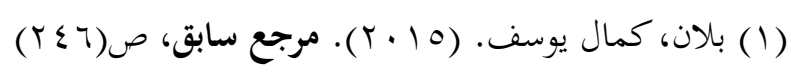

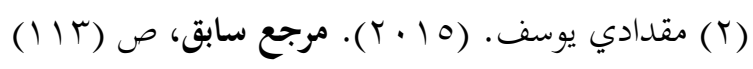

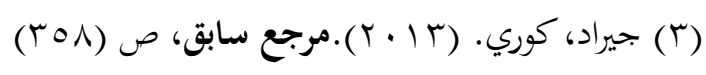


الأثر ويعني تغيير معريف في نظام المعتقدات. (Effect) E (الشعور الجديد. (Feeling) F

وفكرة هذا المعادلة أنّ المشاكل النفسية تنتج عن طريق تفكير الناس بالأشياء، وهذا يعني أن نظام تفكير الشخص B هو الذي يؤدي إلى الانفعال C مثل الغضب والكآبة، وليس

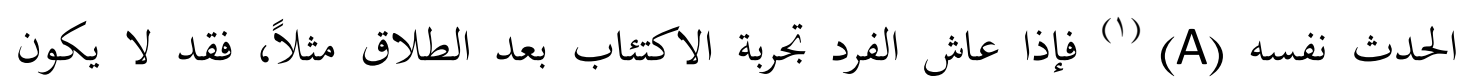

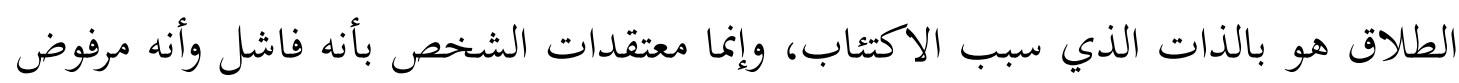

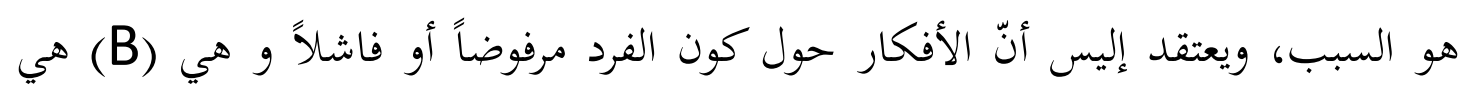

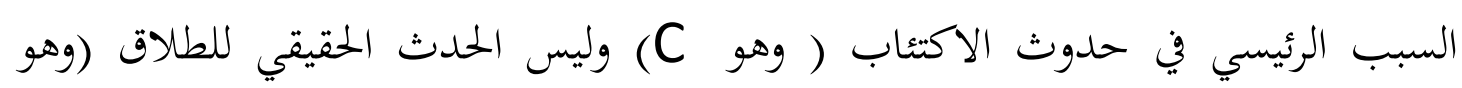

${ }^{(r)}(\mathrm{A}$

إنّ طريقة التفكير (B) هذه تتكون من نظامين اعتقاديين:

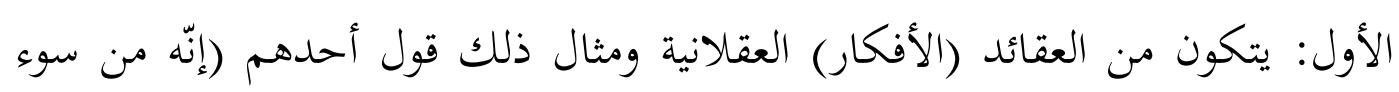
الحظ أن أُطرد من العمل لأنه سيكون من الصعب البحث عن وظيفة جديدة).

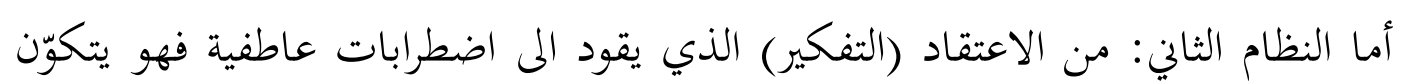

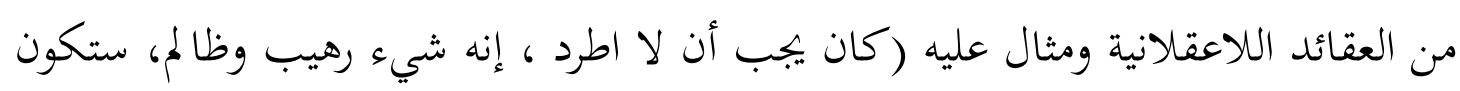

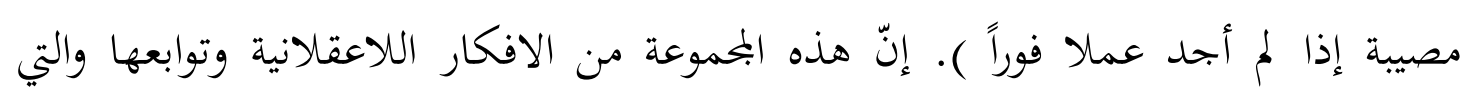

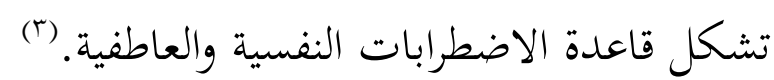
ويصر (إليس) على أنّ اللوم هو السبب الجوهري لمعظم الاضطرابات الانفعالية، ولذلك الفكالك الفية

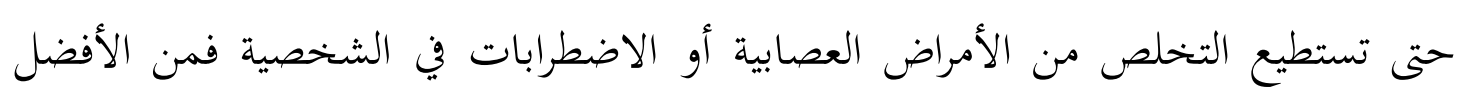

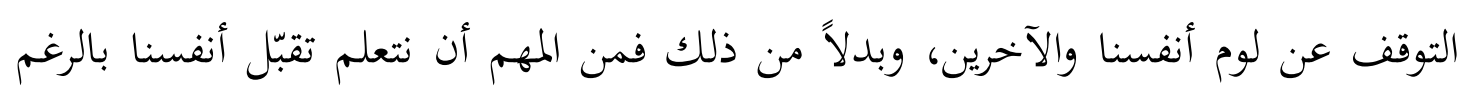

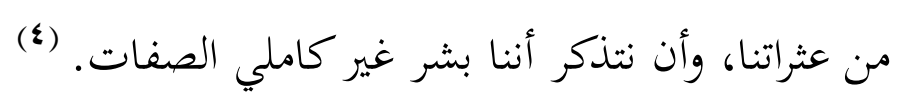

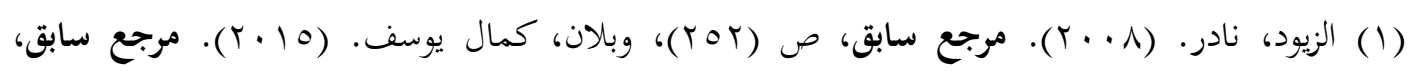

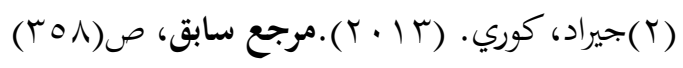

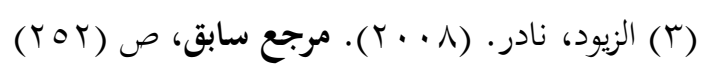

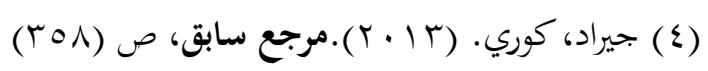




\section{أساليب الإرشاد في ضوء نظرية الإرشاد العقلاني الإنفعالي:}

تركز هذه النظرية على عملية تفنيد المعتقدات (D) خلال جلسات الإرشاد الإدساد في الحياة

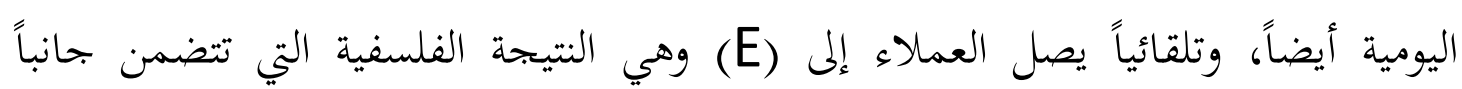

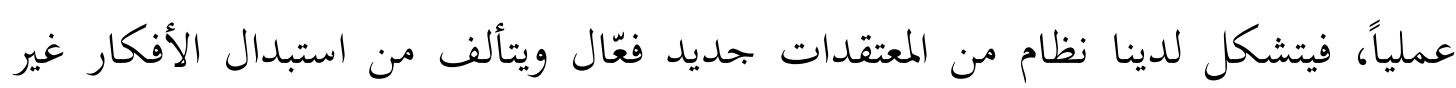

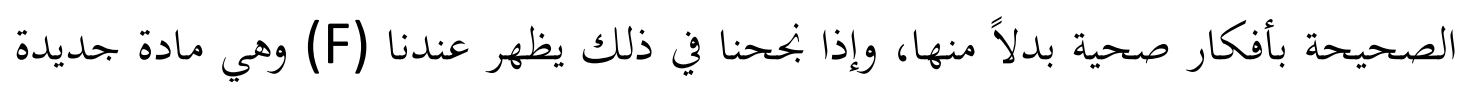

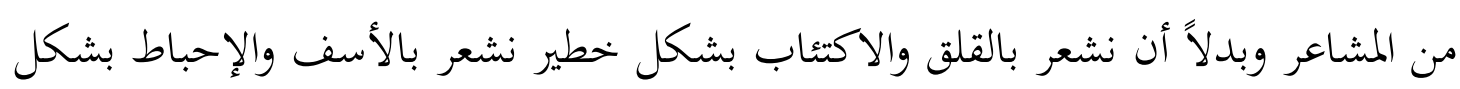

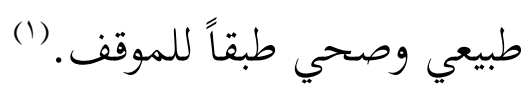

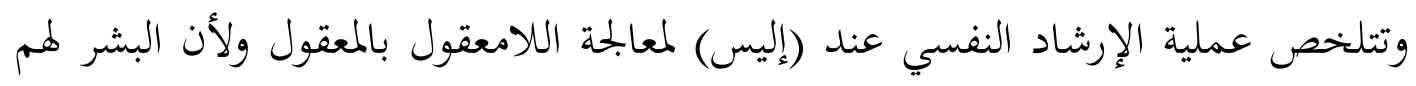

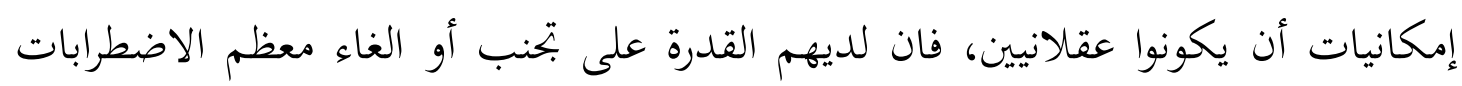

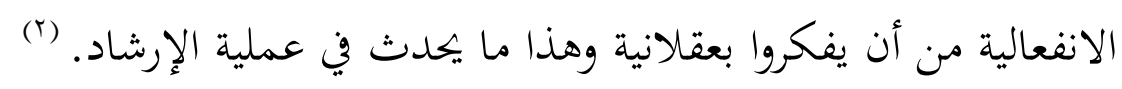
ويمرّ العلاج حسب رأي (إليس) بثلاث خطوات (َ):

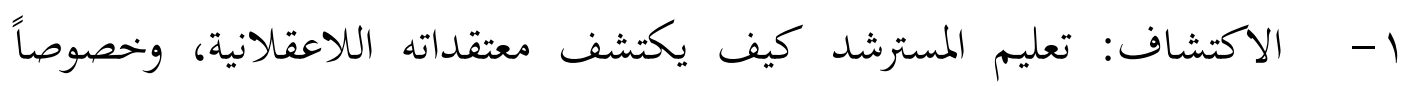
الأحكام المطلقة المفزعة، والتي تؤدي إلى تدني مفهوم الذات. تصنات

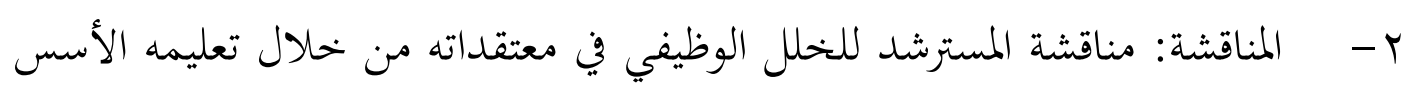

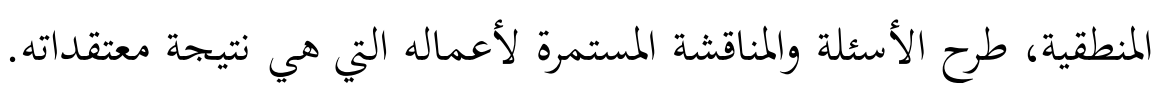

r- - التمييز: تعليم المسترشد التمييز بين المعتقدات العقلانية والمعتقدات اللاعقلانية. إضافة إلى ذلك فإنّ نظرية (إليس) تؤمن أنّ اللغة غير الدقيقة هي من أسباب تشوه

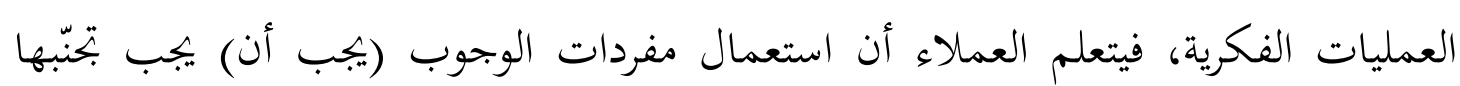

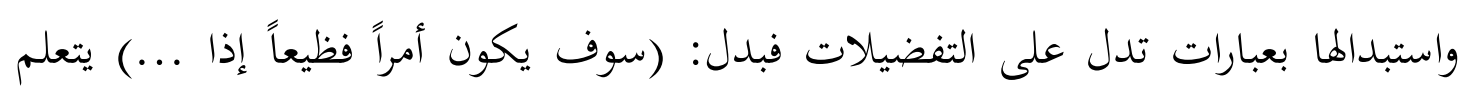

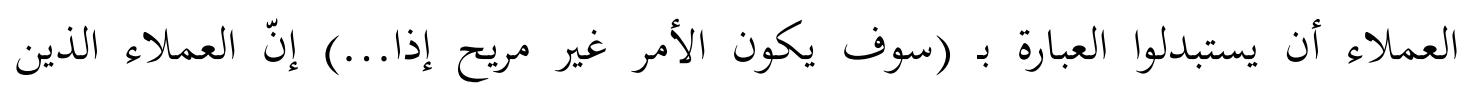

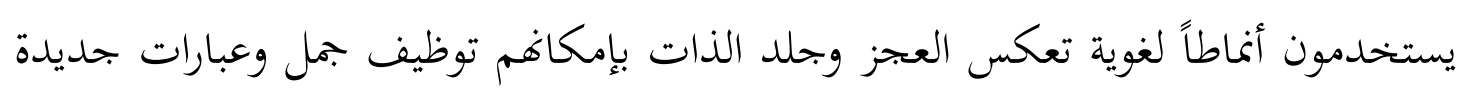

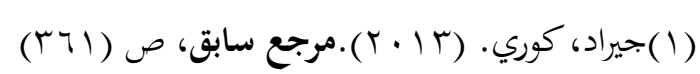

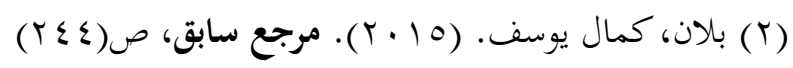

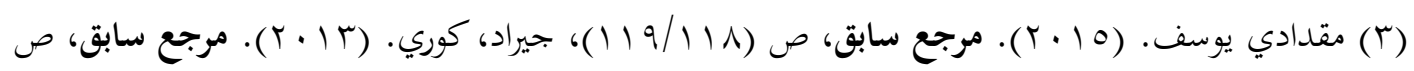


تساعدهم على التفكير وأداء سلوكيات مختلفة، والنتيجة، يبدأون أيضاً بالشعور بشكل (1) مختلف

(r): ويضع (إليس) مخططاً لما يقوم به المرشدون في العلاج العقلي العاطفي 1- تشجيع المسترشد على اكتشاف بعض الأفكار اللاعقلانية التي تثير السلوك المضطرب.

ץ- توضيح الطبيعة اللا منطقية في تفكير المسترشد. ب- استخدام المرح والفكاهة لمقاومة تفكير المسترشد اللاعقلاني. ع - استخدام التحليل المنطقي لتقليل المعتقدات اللاعقلانية عند المسترشد. ه- إطلاع المسترشد على الأثر السلبي لهذه المعتقدات، و اطلاعه على كيفية الفصل بينها وبين المشاعر والسلوكيات المستقبلية المزعجة

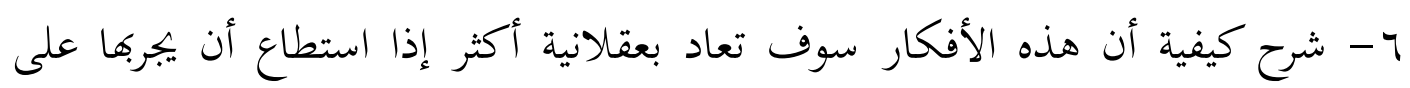
أسس ثابتة. V تزويد المسترشد بالأسلوب العلمي في التفكير، مما يمكنه من إدراك الأفكار اللاعقلانية

وتقليلها سواء بالحاضر أو المستقبل، تلك الأفكار التي قد تؤدي للانتحار أو التفكير به.

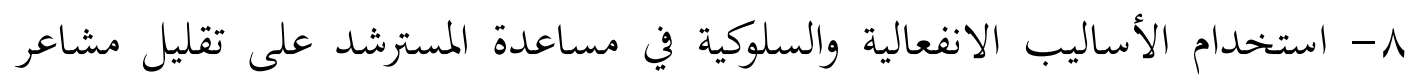
القلق لديه، وذلك من خلال تغيير مشاعره. 


\section{الانتقادات الموجهة إلى النظرية :}

أولاً: إيجابيات النظرية : (1)

حظيت نظرية الإرشاد العقلاني الانفعالي بقبول كبير في أوساط المعنيين بالإرشاد والعلاج النفسي؛ وذلك نظراً لما تتمتع به من مزايا كثيرة من أبرزها:

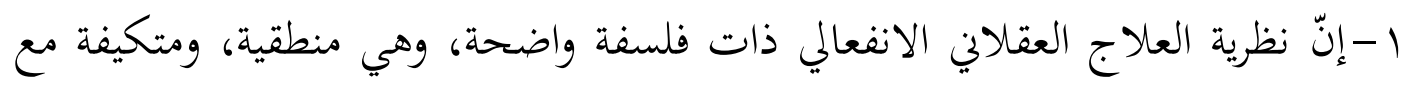
الظروف والواقع، فهي بتعل الإنسان شيئاً مهمًا، وبإمكانه أن يصنع سعادته، ويحقق وإنق

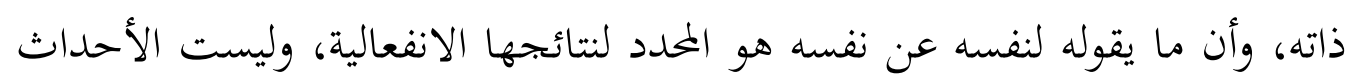
نفسها هي المؤثرة فيه.

r- يكتسب المسترشد في فاية عملية الإرشاد فلسفة عقلانية للحياة.

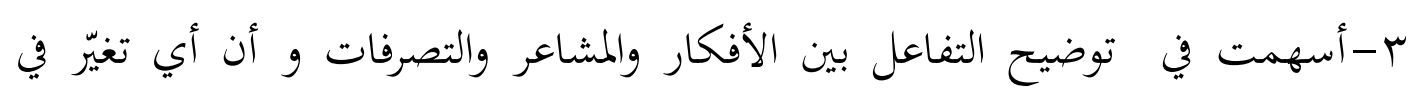
أحدها يؤثر ويغيّر النمطين الآخرين.

ع - تنوع الطرق الإرشادية التي يستخدمها الإرشاد العقلاي الانفعالي، وبالتالي اتساع دائرة

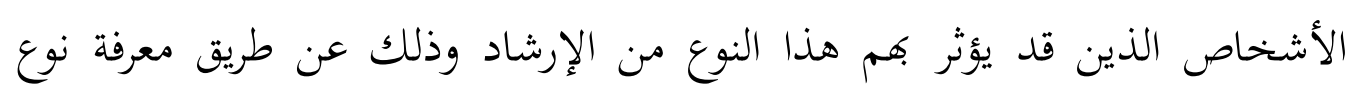
الشخصية التي ينتمون إليها، والتعامل معهم وعلاجهم بالأسلوب المناسب.

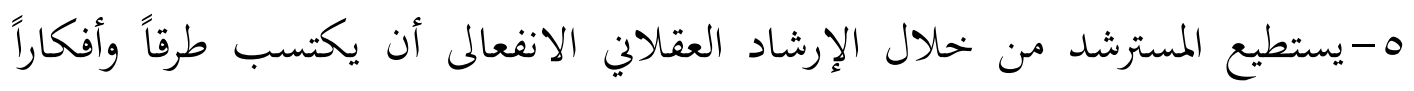

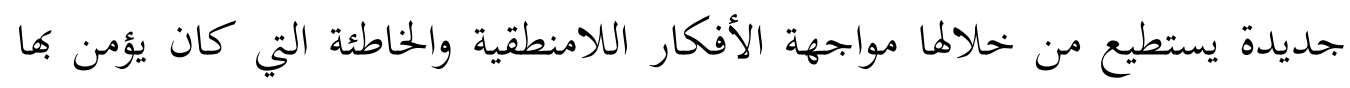
وبالتالي بتجنب الوقوع بها مرة أخرى المستقبل.

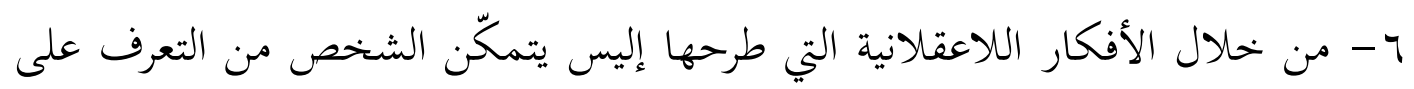

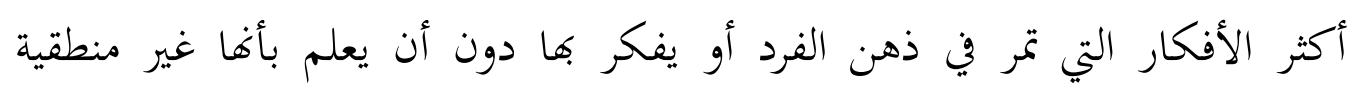
وبالتالي وقْف هذه الأفكار قبل أن تتطور وتصبح واقعية.

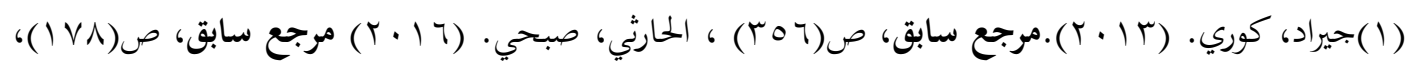

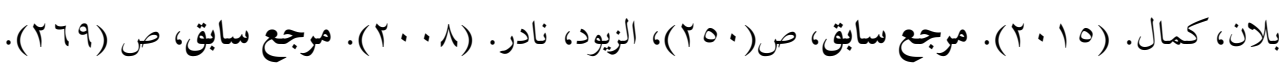


V- تأكيدها على الوسائل العلاجية المتكاملة التي تتضمن الادراك (المعرفة) والسلوك والعواطف. ^-تأكيدها على أن الحوادث الماضية ليست هي التي تسبب للشخص الانفعالات بل

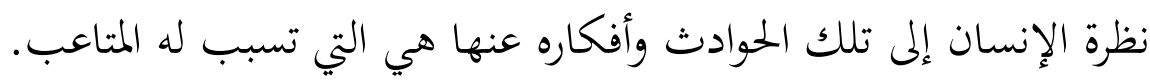
9 - تأكيدها على الوظائف البيتية العملية والسلوكية.

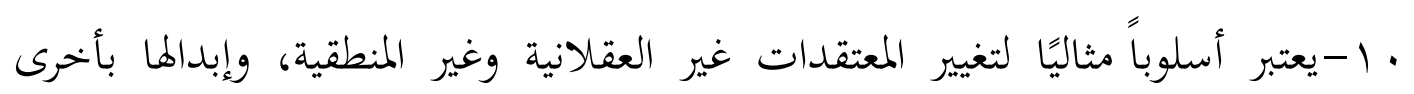
عقلانية ومنطقية 11 ا-يحصن العميل ضد الأفكار غير العقلانية التي قد يتعرض لها مستقبلاً.

\section{ثانياً: سلبيات النظرية: (1)}

مع ما تميزت به هذه النظرية من إيجابيات إلا أها في المقابل وُجّههت لها عدة انتقادات من أبرزها: 1- أنّ الفكرة الأساسية التي قامت عليها النظرية وهي الأفكار اللاعقلانية غير واضحة

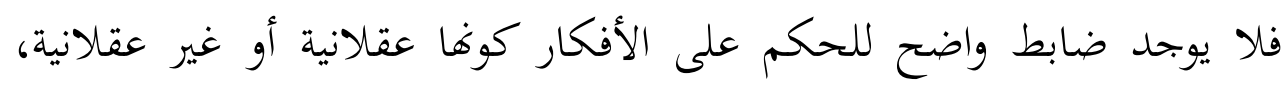

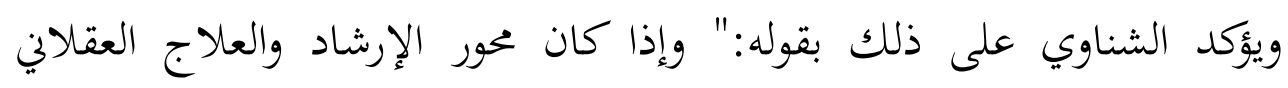

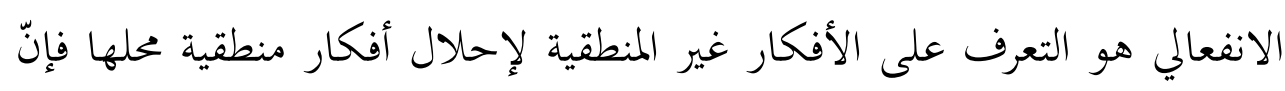

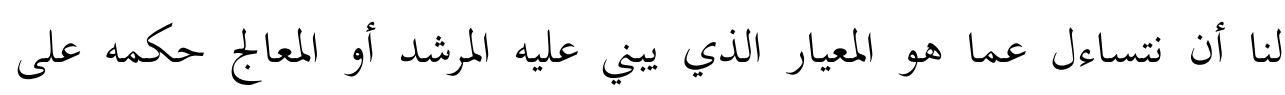

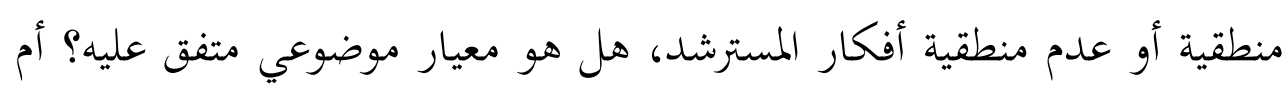

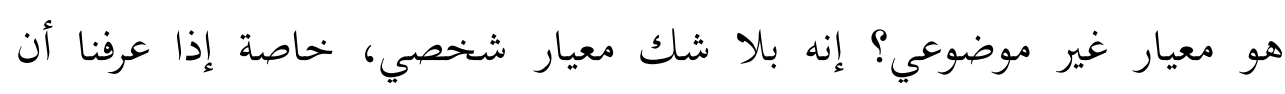

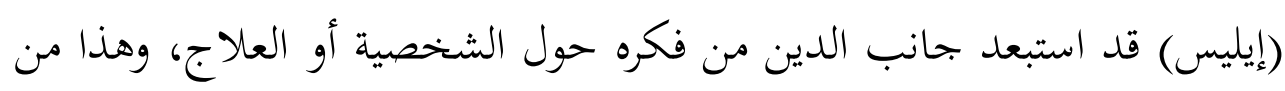

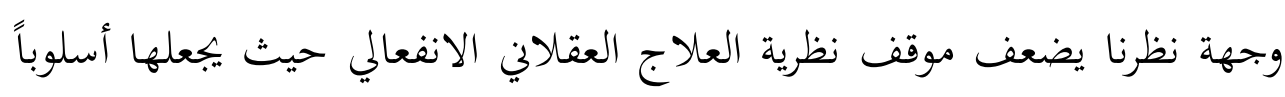

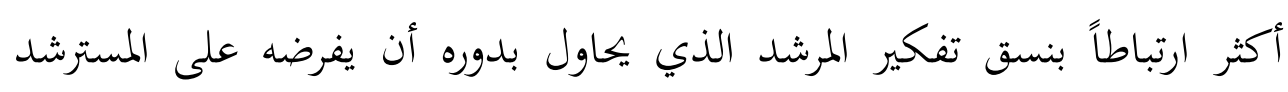

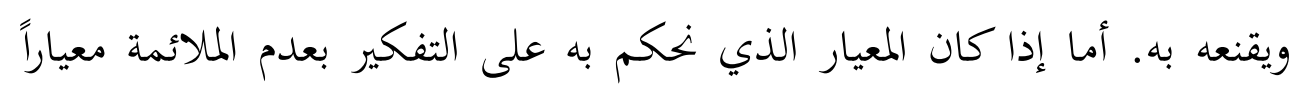

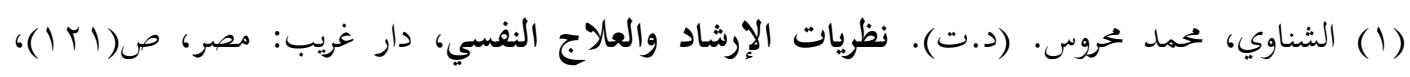

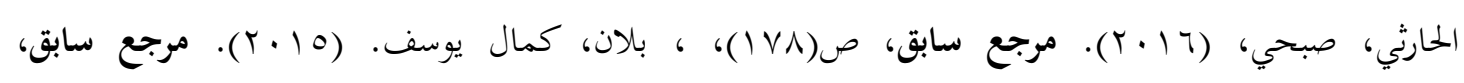

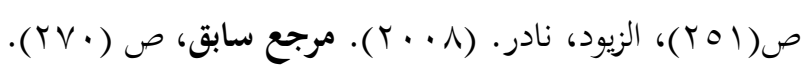


موضوعياً (مثلا معيار الدين، فإن الأمر لن يختلف في التطبيق بين معالج ومعالج أو بين مرشد ومرشد" (1)

r- الإرشاد العقلاني الانفعالي مُباشِر بدرجة كبيرة يُّنضعِع الفرد للإرشاد دون مراعاة لمعتقداته ومفاهيمه.

r- قـ قد يتطرّف بعض المعالجين ويبالغون، فيصبح عملهم أشبه بعملية غسيل الدماغ.

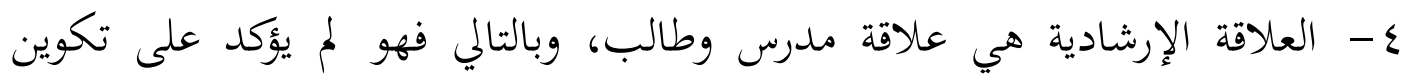

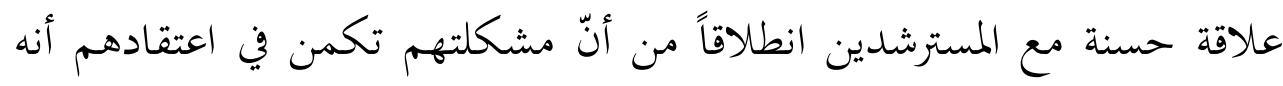
ينبغي أن يلقوا الحب من الآخرين، في الوقت الذي لا يحتاجون إليه فعلاً.

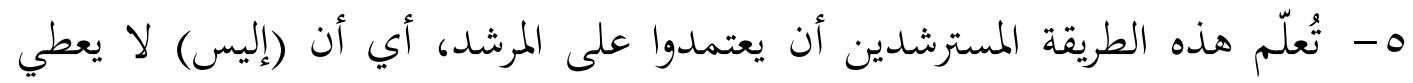
المسترشد دورًا كبيراً في عملية الإرشاد.

4- المجوم المباشر على اتجاهات المسترشد يعتبر تمديداً له وهذا الأمر يزيد من مقاومة المسترشد ويجعل التغيير صعباً إن لم يكن مستحيلاً.

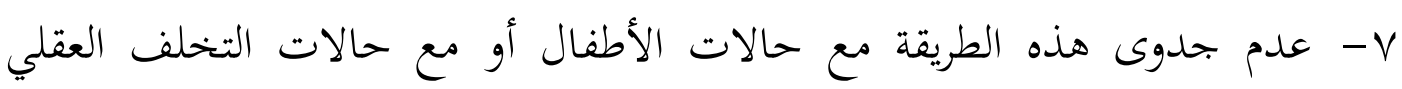
والحالات شديدة الاضطراب لاعتمادها على الاستبصار والتفسير.

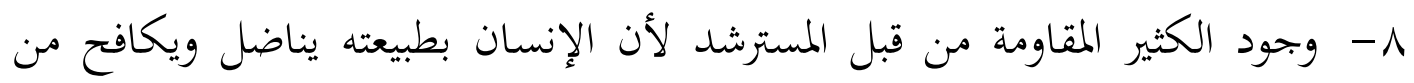

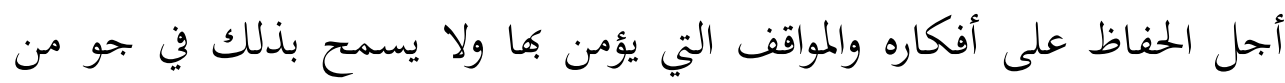
المواجهة المباشرة.

9- اعتبر (إليس) أن العواطف والانفعالات ثانوية، وأعطى الأولوية للعقل في حين أن

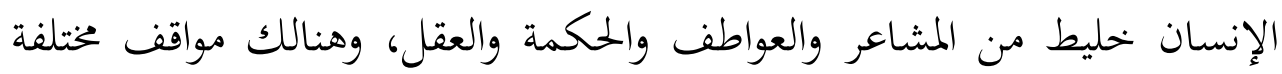

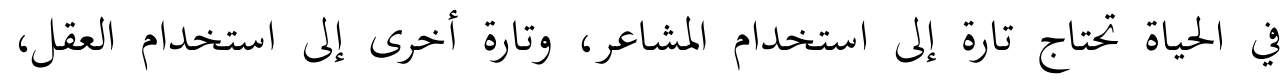
لذلك لا يجوز تفضيل احدها على الآخر.

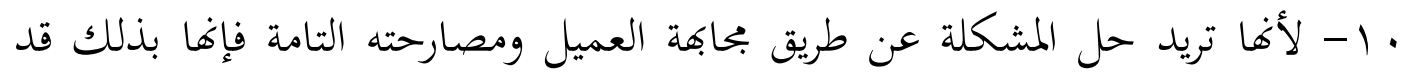
تُسبّب له الأذى النفسي أكثر من أن تعالجه.

(1) الشناوي، محمد محروس، (د.ت) مرجع سابق، ص( I I ) 


\section{المبحث الثاني: نقد النظرية في ضوء المنهج الإسلامي : أولاً : نقد نظرة الإرشاد العقلاني الانفعالي إلى الإنسان:}

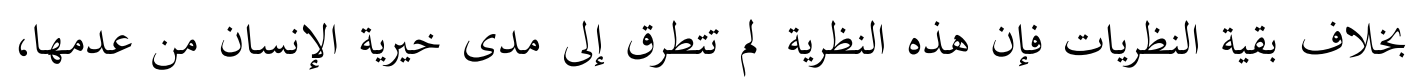

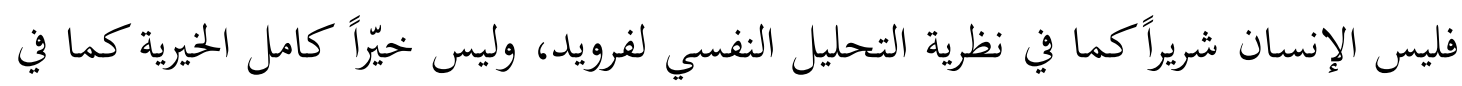
نظرية روجرز، وليس خالياً من الخير والشر كما في النظرية السلوكية. ولعل مردّ ذلك أنّ (إليس) ركّز نظريّته على الأفكار العقلانية وغير العقلانية وعلاقة ذلك ولك بالسلوك والاضطراب، على اعتبار أنّ الاضطراب مردّه إلى التفكير غير العقلاني، وأنّ طريقة تفكير الإنسان هي المسؤولة عن شعور الإنسان بالسعادة أو الاضطراب.

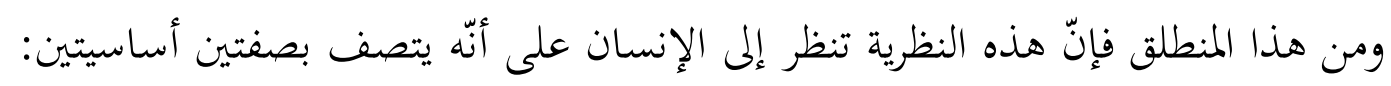

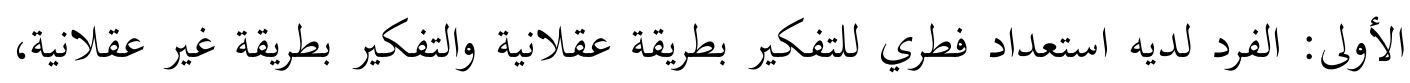

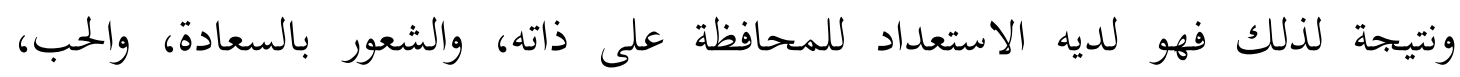
والتواصل مع الآخرين، وي المقابل لديه استعداد فطري لعكس ذلك.

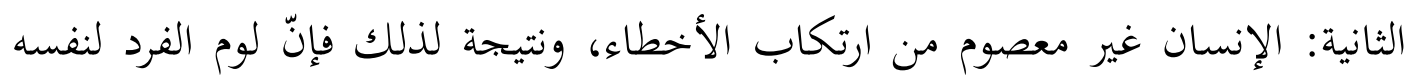
على أخطائه ولوم الآخرين له عامل رئيس في حدوث الإنسير الاضطراب النهاب النفسي. وعند التأمل في الصفة الأولى: (الاستعداد الفطري للتفكير بطريقة عقلانية وغير عقلانية)

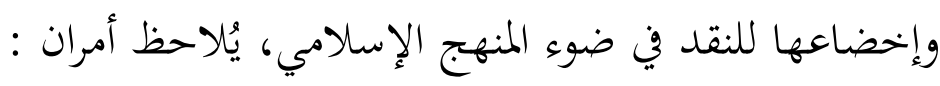
الأمر الأول: أنّها أقرّت بحرية الإنسان في اختيار طريقة التفكير التي يريد وحرية

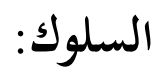
إنّ هذه الحرية في التفكير التي منحها (إليس) للإنسان موجودة في المنهج الإسلامي،

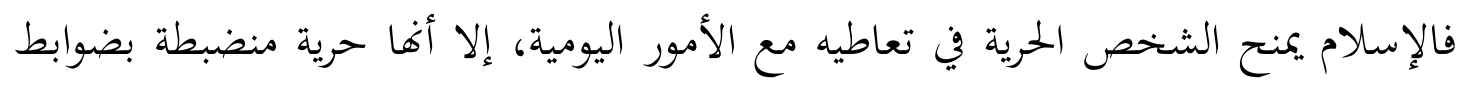

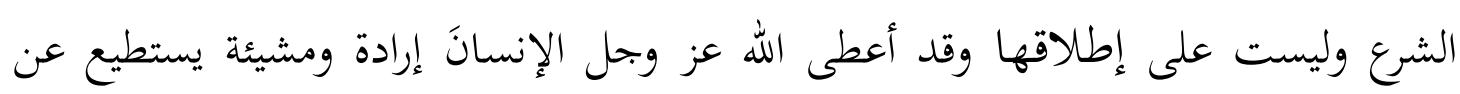

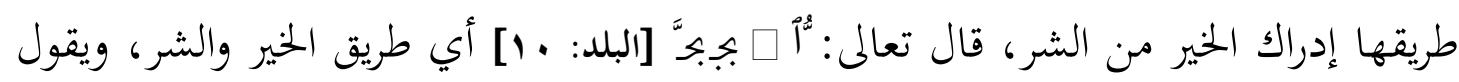

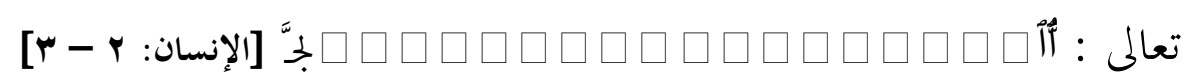


قال الرازي - رحمه الله - قوله تعالى: "إنا هديناه السبيل أخبر الله تعالى أنه بعد أن ركّبه وأعطاه الحواس الظاهرة والباطنة بيّن له سبيل الهدى والضلال، والآية دالة على أن إعطاء الحواس كالمقدّم على إعطاء العقل، والأمر كذلك؛ لأن الإنسان خُلِّقَ في مبدأ الفطرة خحالياً عن معرفة الأشياء، إلا أنه أعطاه آلات تعينه على تحصيل تلك المعارف، وهي الحواس

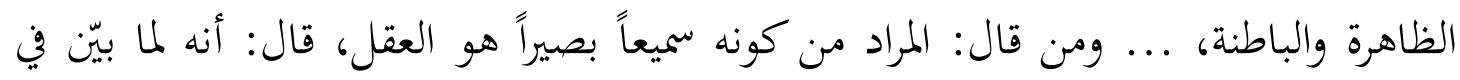
الآية الأولى أنه أعطاه العقل بيّن في هذه الآية، أنه إنما أعطاه العقل ليبيّن له السبيل ويظهر هرئه

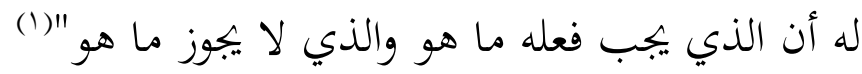

الأمر الثاني: أنها اختزلت الإنسان في الجانب العقلي وجانب التفكير تحديداً:

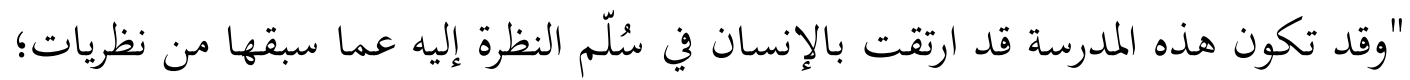
إذ قدّرت للعقل أهميته، ولكن مرة أخرى أين المشاعر؟ ومرة أخرى العقل من أين وإلى أين إلى

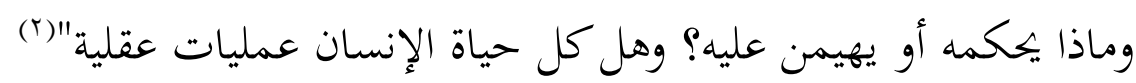

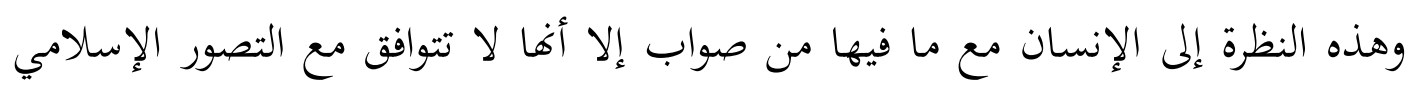

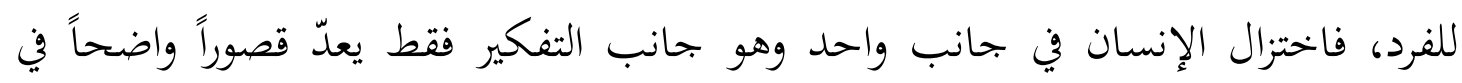
تصوّر كينونة الإنسان الذي يتكوّن من جسد وعقل وروح حسب رؤية المنهج الإسلامي. إنّ نظرة التربية الإسلامية إلى الإنسان تتميّز بشموليتها وتكاملها وواقعيتها، و المقصود

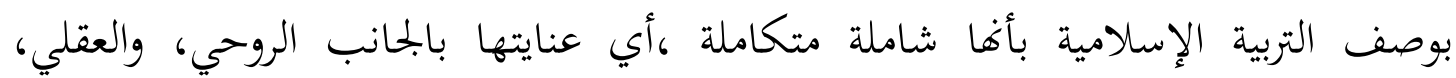
والوجدائ ، و الأخلاقي ، الاجتماعي، والجسدي في تكوين الشخصية الإنسانية، وفق معيار الاعتدال، و الاتزان، فلا إفراط في جانب دون غيره، ولا تفريط في جانب لحساب

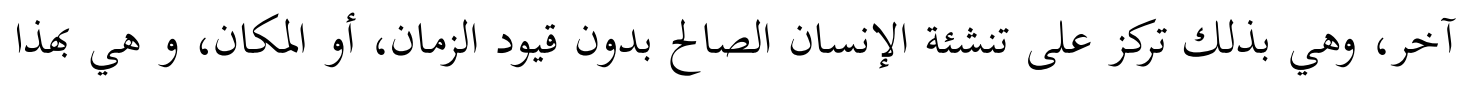

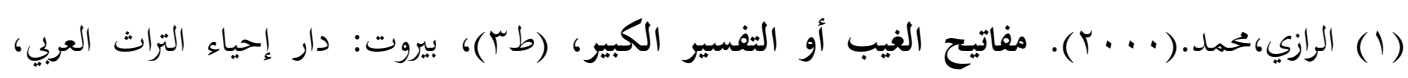

$(V \leqslant 1 / r \cdot)$

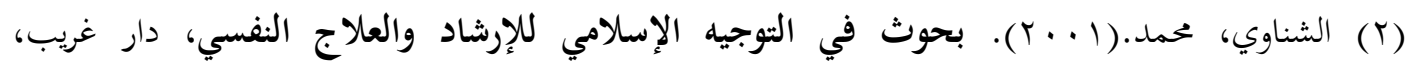
القاهرة.ص( (Y) ( ). 
الهدف الخلاّق فاقت التربية الحديثة التي تنشد تكوين المواطن الصالح حسب معايير البيئة التي يعيش فيها، أو العصر الذي يجيا فيه. (1) والآيات القرآنية والأحاديث النبوية في معنى التوازن كثيرة جداً وفيها الدلالة على أهمية الاعتدال في تنمية الروح والبدن وكونه من التكليف، لما في العدول عنه من تغيّر الهدف الذي خُلِق الخلقق له فكانت سنة الهادي البشير صلى الله عليه وسلّم تدعو إلى ذلك التوازن؛ لأنّ تهن من خلاله تتحقق القوة الحسية والمعنوية ولا بد لأحدها من الآخر ... و المراد من هداية السبيل خلق الدلائل، وخلق العقل الهادي وبعثة الأنبياء وإنزال الكتب، كأنه تعالى قال: خلقتك للابتلاء ثم أعطيتك كل ما تحتاج إليه ليهلك من هلك عن بينة وليس معناه خلقنا

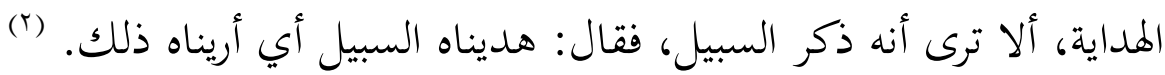
فالمنهج الإسلامي يرى في الإنسان الجانب الروحي وهو المكوّن الأهم للإنسان ومما يتميز إنسان به المنهج الإسلامي عن غيره من المناهج، وهذا الجحانب تتم تنميته عن طريق ربط الفرد بخالقه

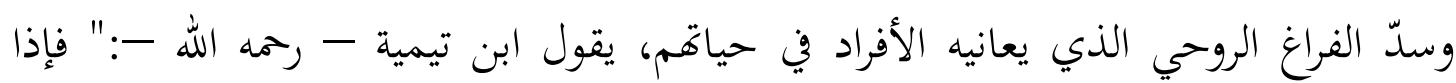

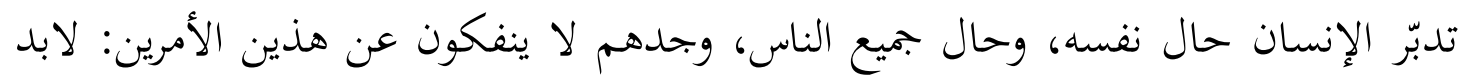
للنفس من شيء تطمئن إليه وتنتهي إليه محبتها وهو إلهها، ولا بد لها من شيء تثنق به

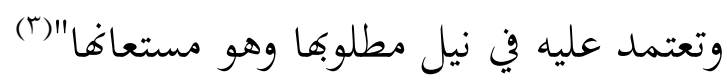
ويقول السّفّاريني -رحمه الله - مؤكداً هذه القضية:" وقد جاءت مهن الرسل وأنزلت الكتب بتقرير ما استودع سبحانه في الفطر والعقول من ذلك وتكميله وتفصيله وزيادته حسناً إلى ونى

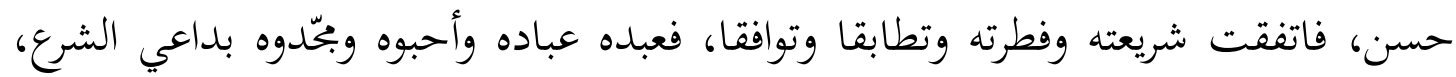
وداعي الفطرة والعقل، فاجتمعت لهم الدواعي ودعتهم إلى وليّهم وإلههم وفاطرهم، فأقبلوا

(1) الزنتاني، عبد الحميد. (ب991 ). أسس التربية الإسلامية في الأحاديث النبوية، (طץ) ليبيا: الدار العربية

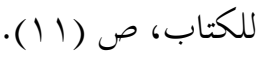

(Y) عبد الحميد، علي. (צ (99 ). التصفية والتربية وأثرهما في استئناف حياة الأمة، (طץ)، الأردن: دار

التوحيد، ص (• (Y).

(T) ابن تيمية، أحمد. (1997 (19). مجموع فتاوى شيخ الإسلام، المملكة العربية السعودية: بحمع الملك فهد

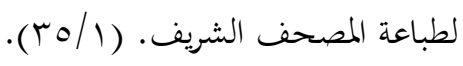


إليه بقلوب سليمة لم يعارض خبره عندهم شبهة توجب ريباً وشكاً، ولا أمره شهوة توجب

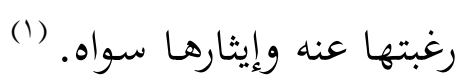
ويرى المنهج الإسلامي كذلك في الإنسان الجانب الجسدي، ويتعامل معه بواقعية فالجسد

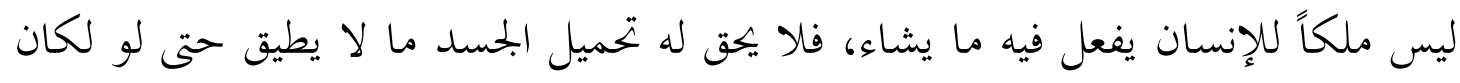

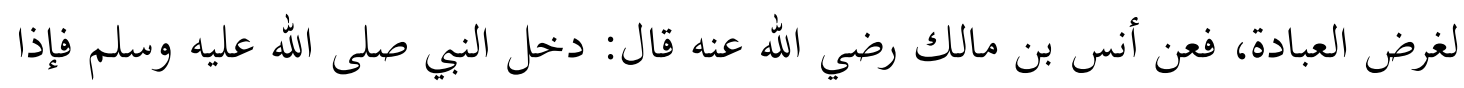

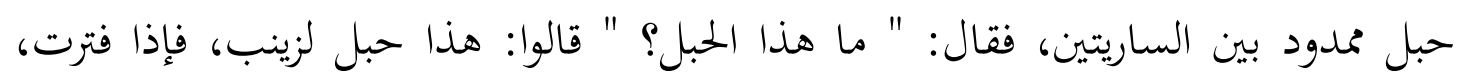

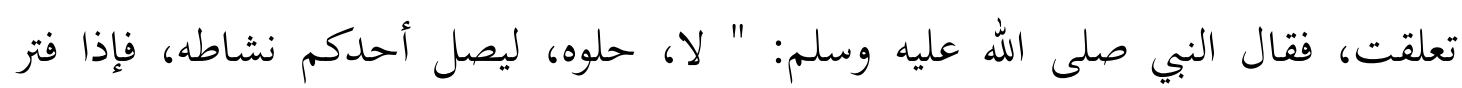
فليقعد" (r) قال ابن حجر - رمهه الله -:"وفيه الحث على الاقتصاد في العبادة والتعقق فيها والأمر

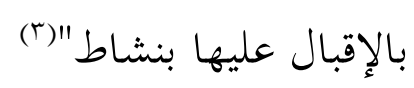

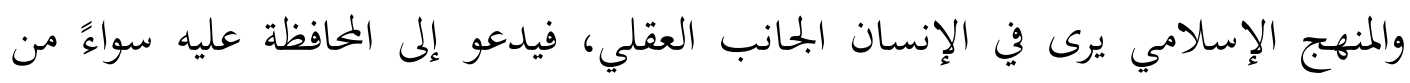

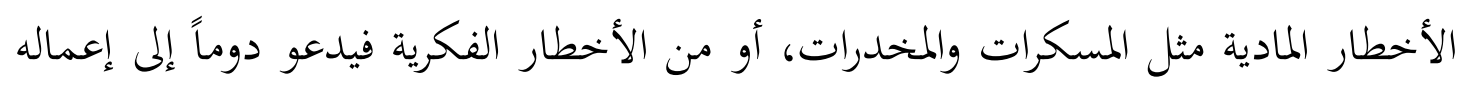
عن طريق التفكّر والتفكير المستمر.

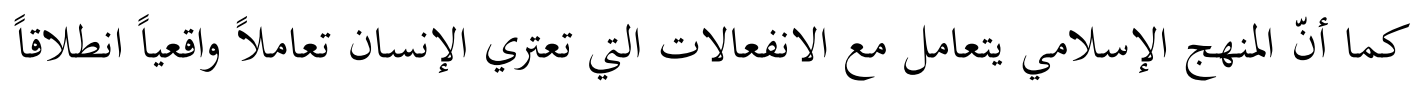

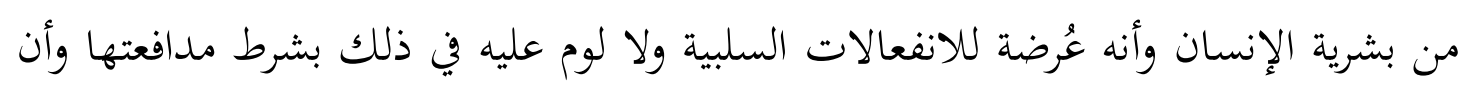

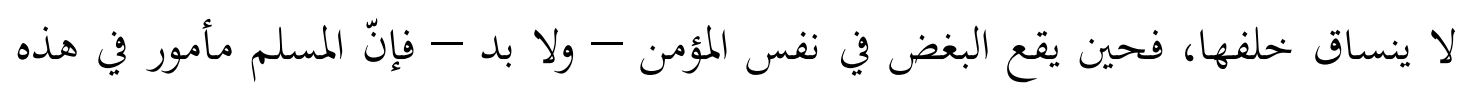

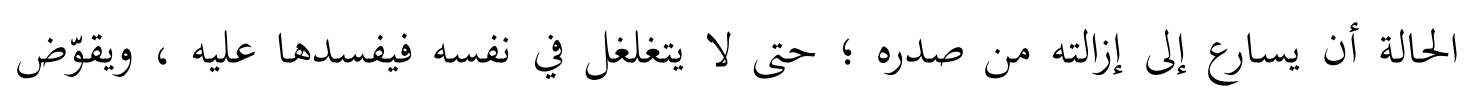

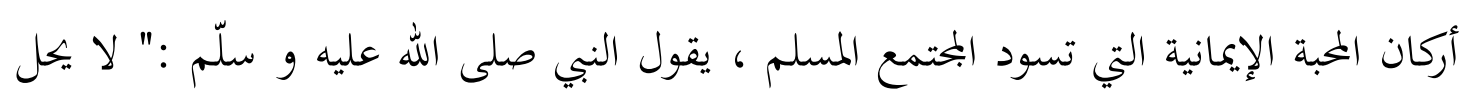

(1) السفاريني، أمد. (19/9)). لوامع الأنوار البهية وسواطع الأسرار الأثرية، (طr)، سوريا: المكتب

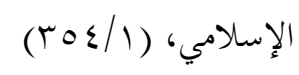

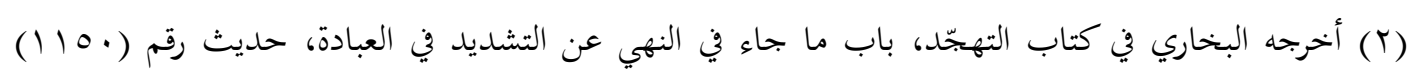

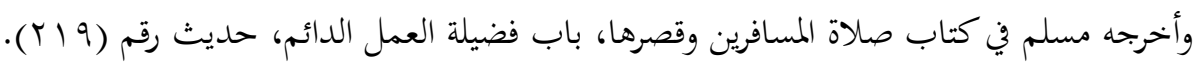

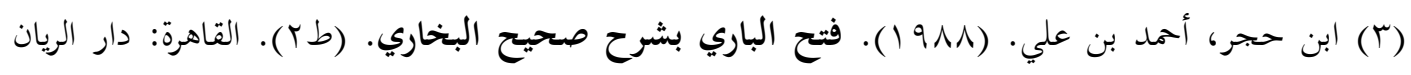
$(\xi 0 / r)$ 
لمسلم أن يهجر أخاه فوق ثلاث ليال ، يلتقيان فيعرض هذا ، و يعرض هذا، و خيرها

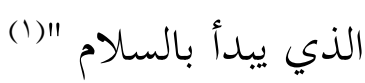
وإذا كان البغض انفعال لا بد أن يعتري الإنسان، فإن المسلم يجعل بغضه في أمر سامٍا

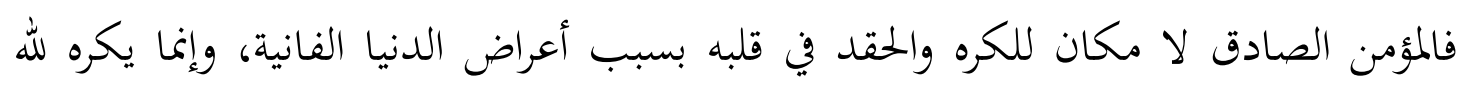
ويبغض لله، فهو يكره أن يعتدي أحد على حق من حقوق الله ويكره أن يرى أحداً يظلم

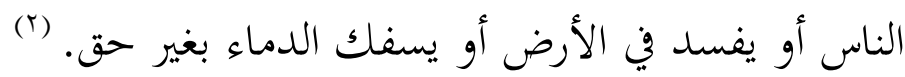

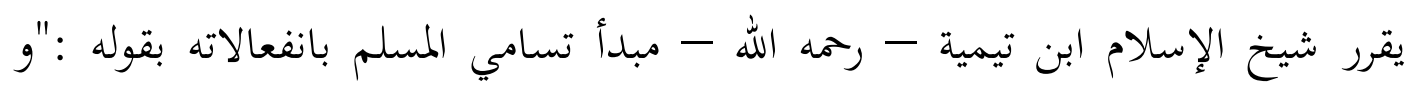

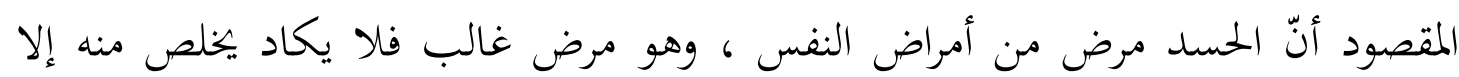

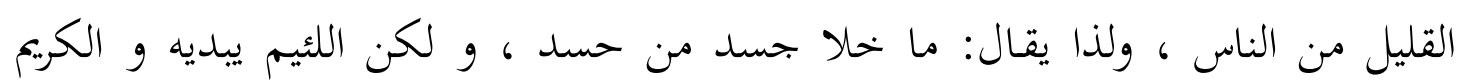

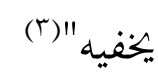

ثانياً: نقد نظرة الإرشاد العقلاني الانفعالي في كيفية حدوث الاضطراب: تقدّم رأي (إليس) أنّ الاضطراب النفسي يحدث نتيجة لوجود أفكار غير عقلانية لدى لوى الفرد، وأنّ اللوم سبب رئيس كذلك لحدوث الاضطراب النفسي، وسيتناول الباحث هاتين

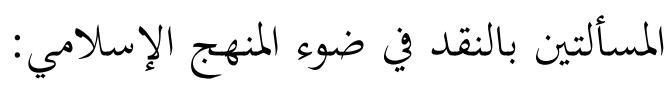

\section{1- التفكير العقلاني وغير العقلاني في ضوء المنهج الإسلامي:}

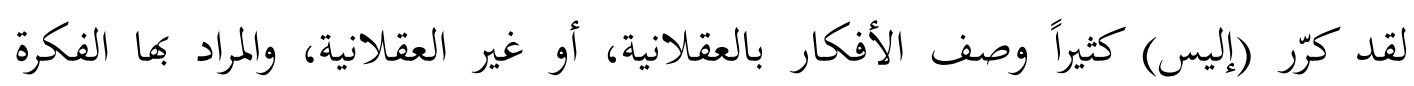
المنطقية المقبولة، والفكرة غير العقلانية هي الفكرة غير المنطقية أو غير الواقعية، وليس وصعيس

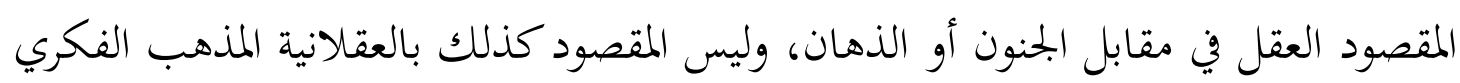
الذي يعتمد العقل في إثبات الأشياء حتى لو عارضت الوحيين.

(1) أخرجه مسلم ، في كتاب البر و الصلة و الآداب ، باب تحريم المجر فوق ثلاث بلاعذر شرعي ، حديث رقم

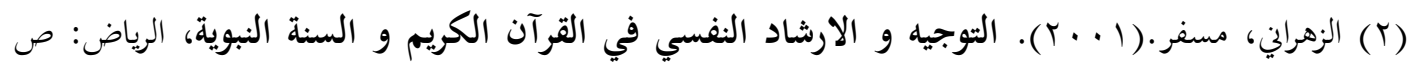

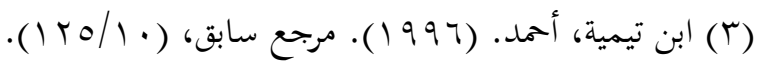

$$
\begin{aligned}
& r \text {. }
\end{aligned}
$$


والمطالع لما دوّنه العلماء المسلمين حول العقل والفكر لا يجد لفظة (التفكير العقلاني وغير

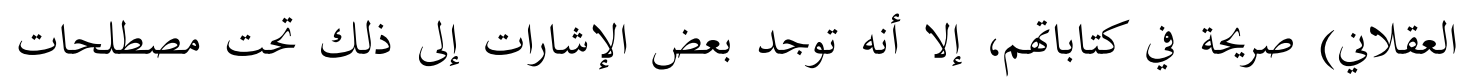

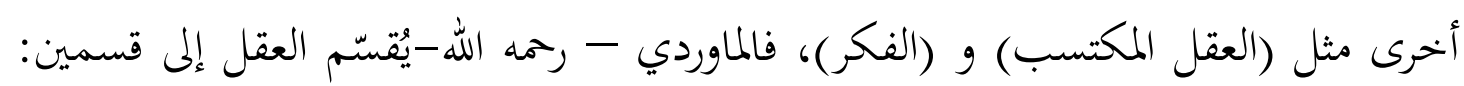

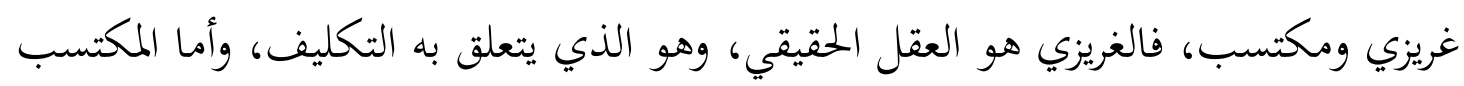

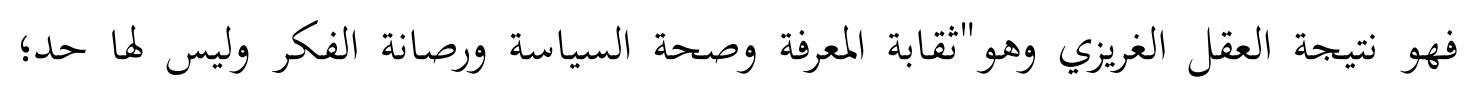

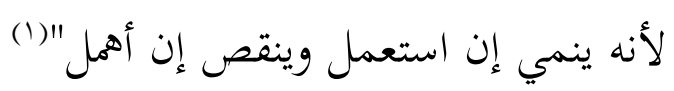

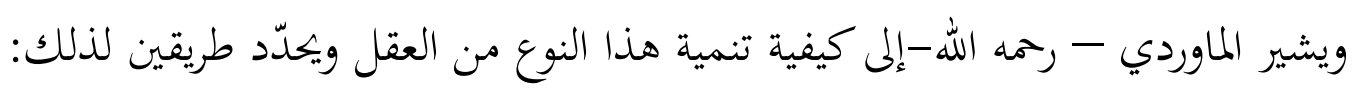
الأول: كثرة الاستعمال وكثرة التجارب ومعايشة الأمور.

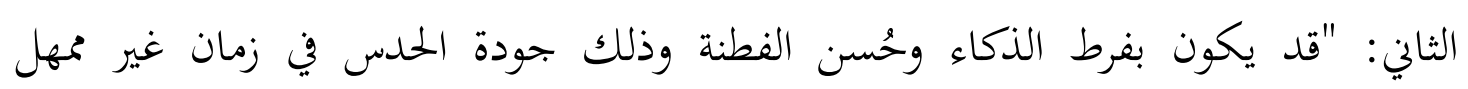
للحدس" (ب) الناي:

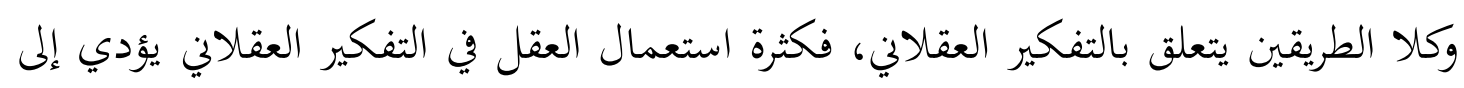

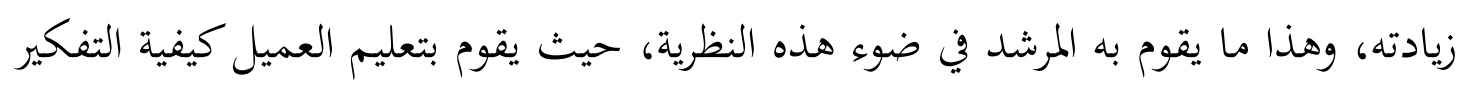

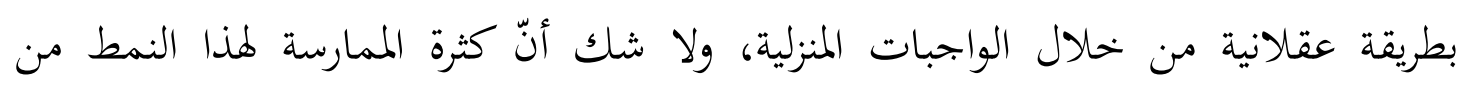

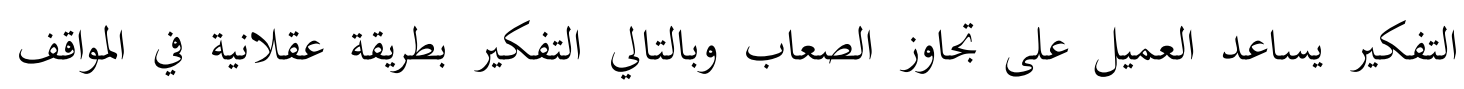

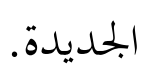

وأما مصطلح الفكر فيعرّفه الجرجاني بأنه: ترتيب أمور معلومة للتأدي إلى بحهول"(")

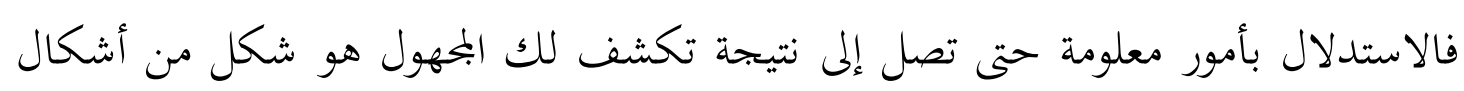
التفكير العقلاني.

وأوضح من هذا في الإشارة إلى التفكير العقلاني تعريف السّّّاريني - رحمه الله - للتفكّر

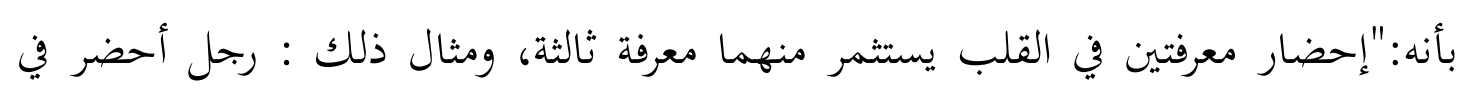

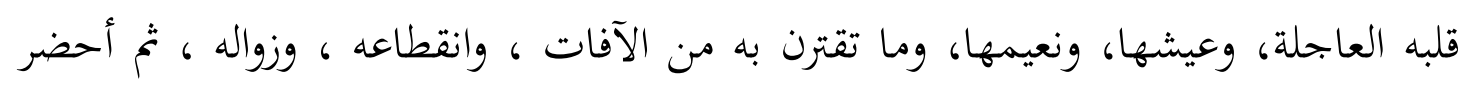

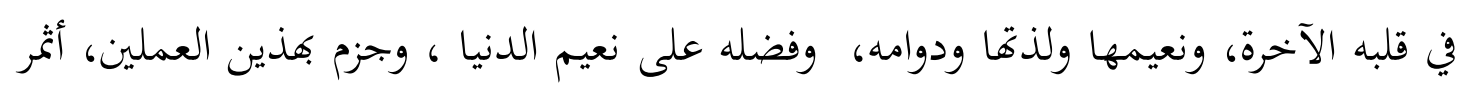

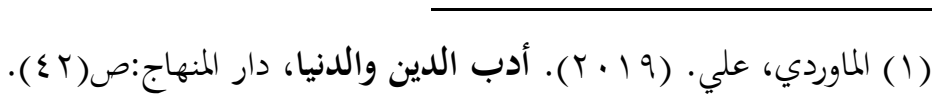

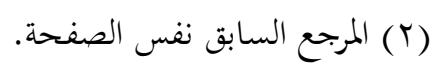

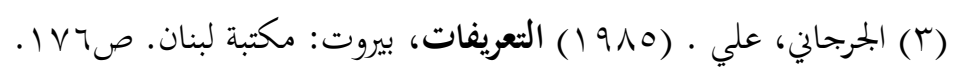


له ذلك علماً ثالثاً، وهو أنّ الآخرة ونعيمها الفاضل الدائم ، أولى عند كل عاقل بايثاره من

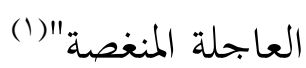

ومن هنا فإنّ عناية المنهج الإسلامي بالعقل والتفكير تعدّ عناية فائقة، وهذا ظاهر في أدبيات

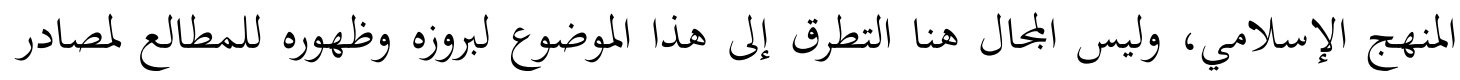

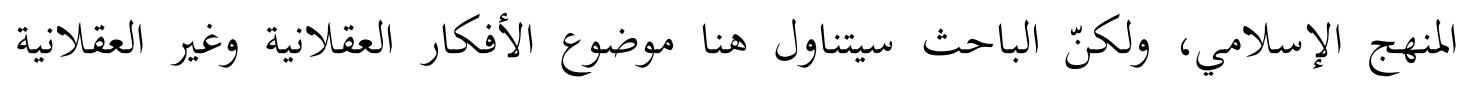
وطريقة المنهج الإسلامي في التعامل معها كمدنل لنقد نظرية الإرشاد العقلائ الإني الانغعالي.

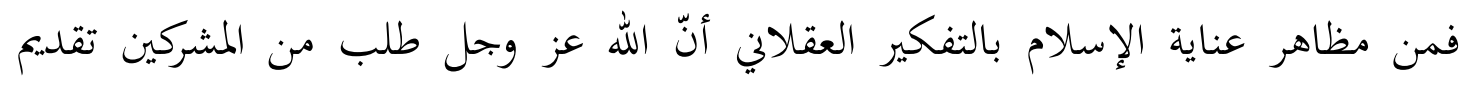

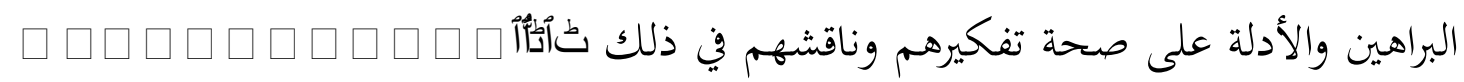

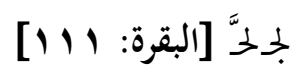

وفي هذا تربية من الله لعباده أن يتعودوا على التفكير العقلاني المبني على الأدلة والبراهين،

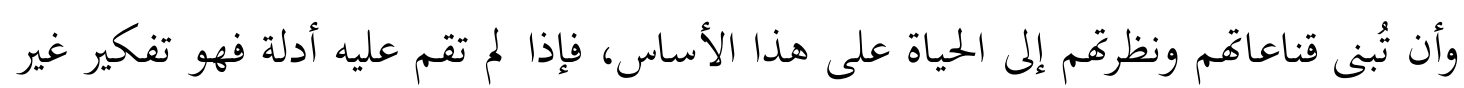
عقلاني. يقول شيخ الإسلام ابن تيمية: فالاستدلال على الخالق بخلق الإنسان في غاية الحسُن

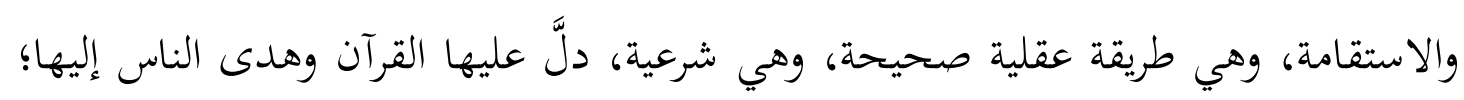

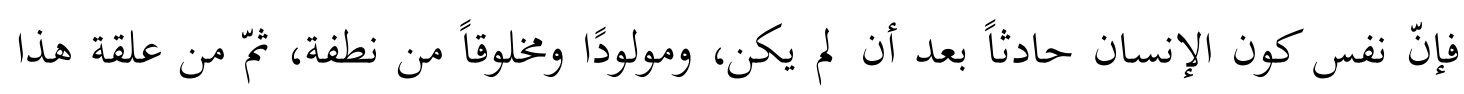

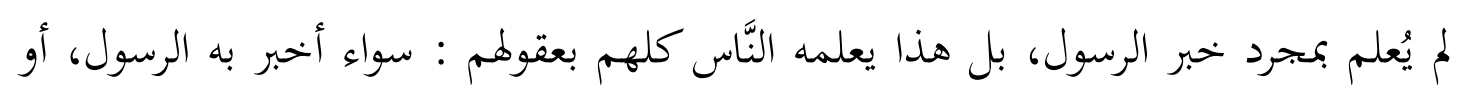

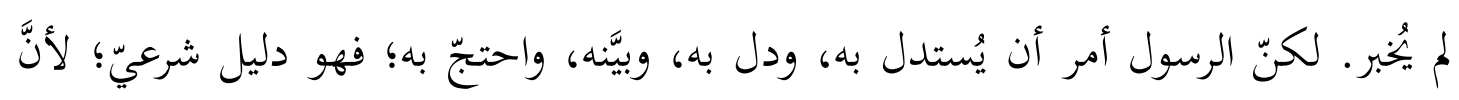

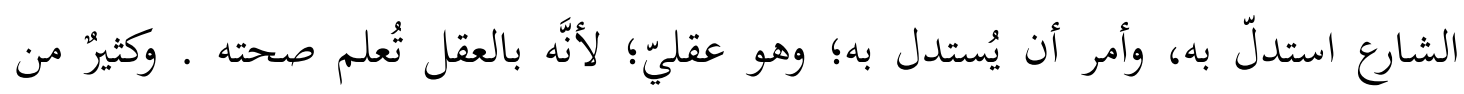

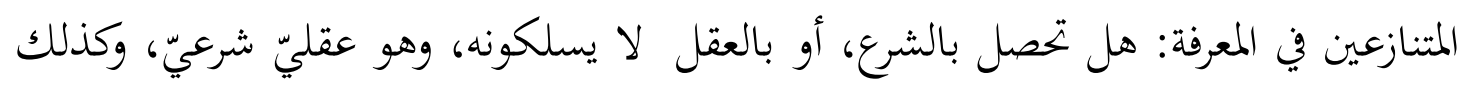

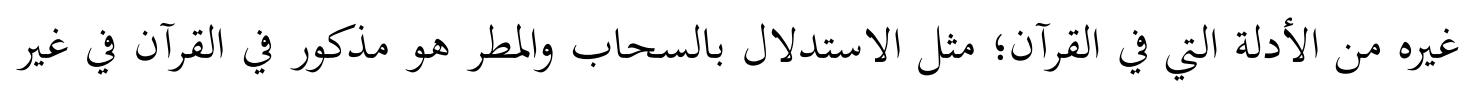

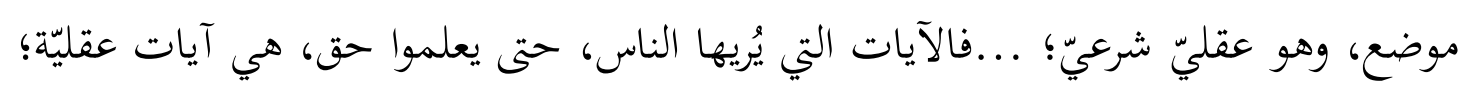

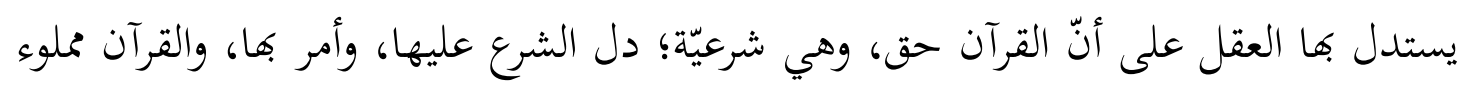

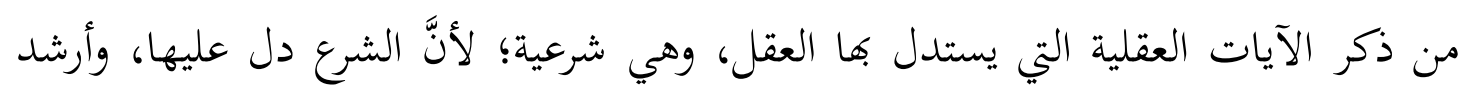

(1) السفارين، أحمد. (1997). غذاء الألباب لشرح منظومة الآداب، بيروت: دار الكتب العلمية، (؟/9). 
إليها، ولكن كثيرّ من النّاس لا يُسمّي دليلاً شرعيًا إلا ما دلّ بمجرّد خبر الرسول، وهو

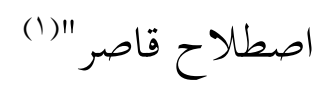
كما أنّ المتأمل في مصادر التربية الإسلامية يجد أنّ موضوع التحري عن الأفكار غير

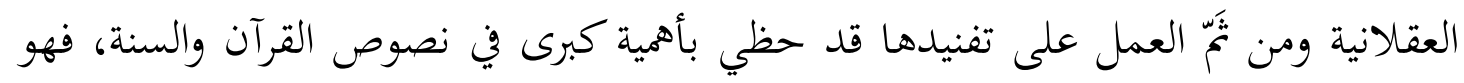

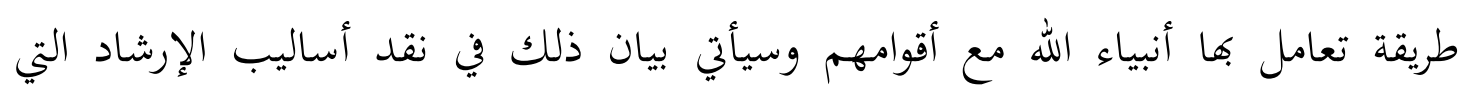

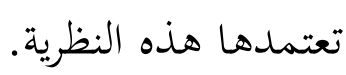

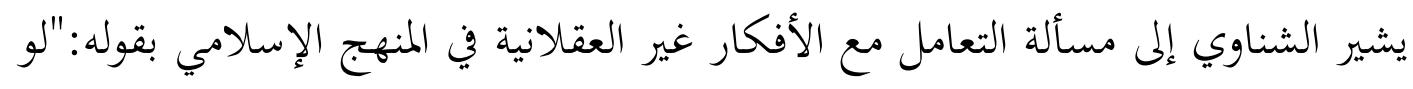

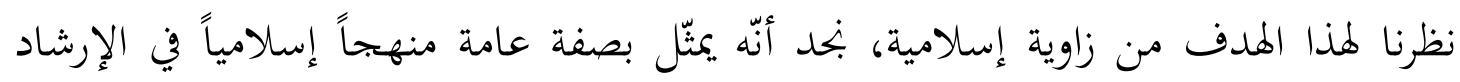

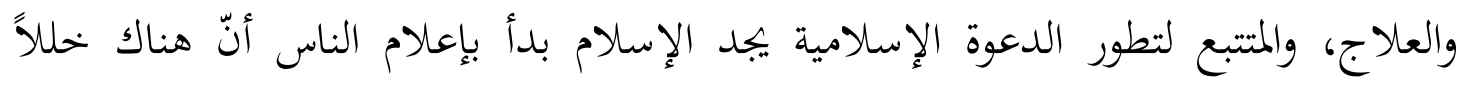

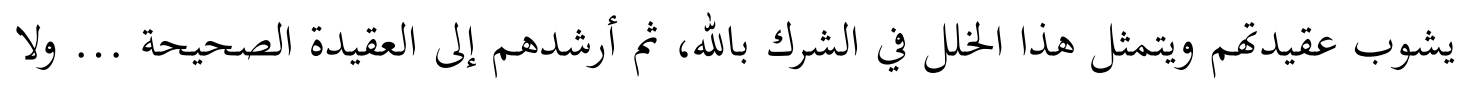

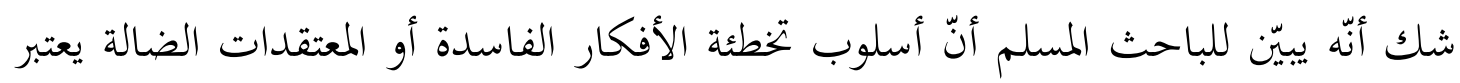

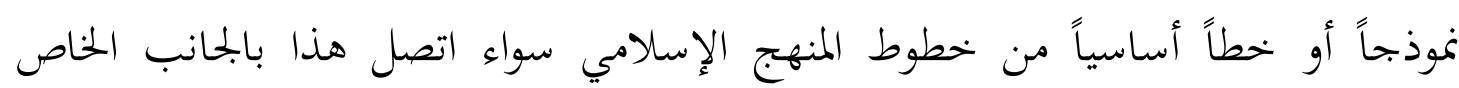

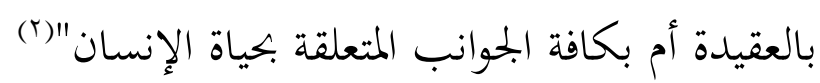

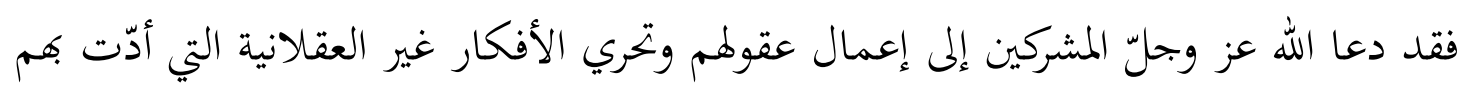

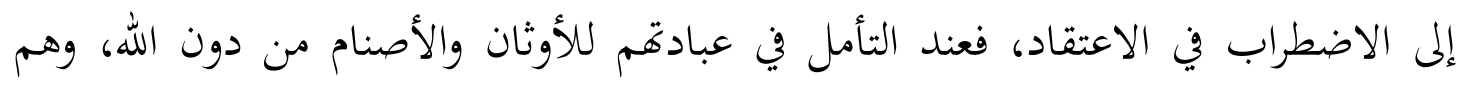

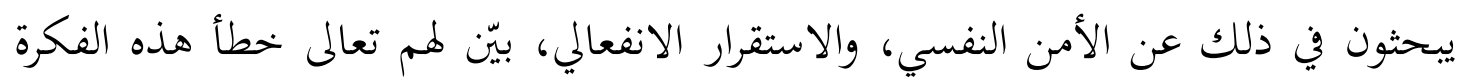

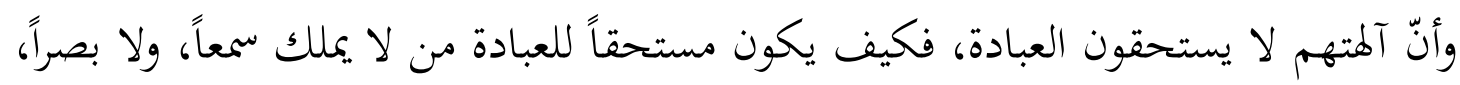

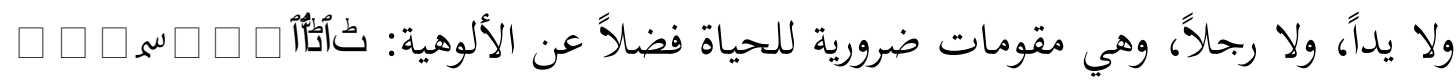

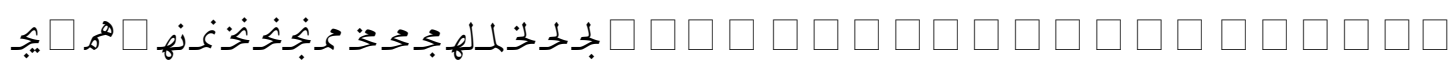

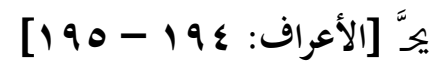
إنها دعوة إلى استخدام التفكير العقلاني في مدى استحقاق هؤلاء للعبادة من دون الله.

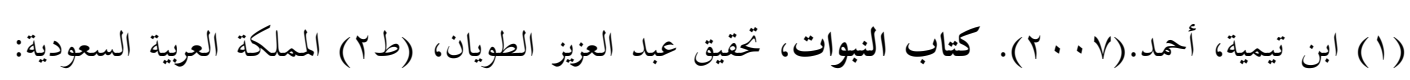

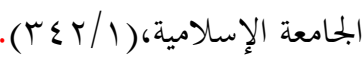

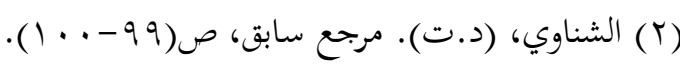


قال الطبري -رحمه الله-: "يقول جل ثناؤه: فإن كانت آلتكم التي تعبدوها ليس فيها شيء

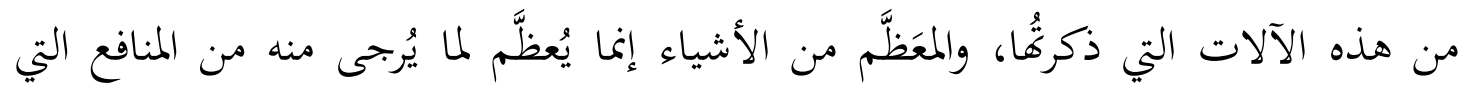
توصل إليه بعض هذه المعاني عندكم، فما وجه عبادتكم أصنامكم التي تعبدوفها، وهي خحالية

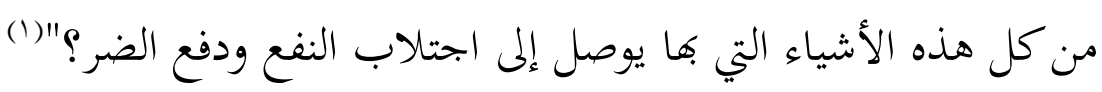
ويقول أبو السعود -رحمه الله- عند قوله تعالى: "ُأيى [البقرة:IVI] "فهم لا يعقلون شيئاً لأن طريق التعقّل هو التدبر في مبادي الأمور المعقولة

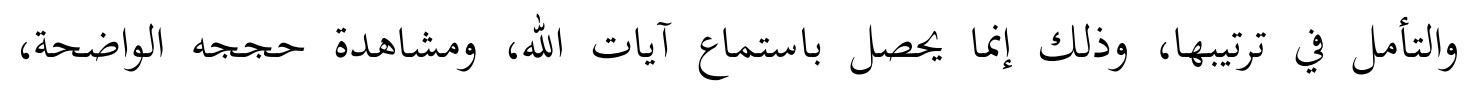

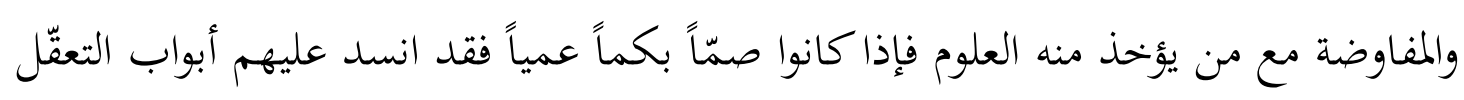
وطرق الفهم بالكلية" (r) وفكرة أخرى غير عقلانية تؤدي إلى اضطراب الاعتقاد وخلل في بناء القناعات، فليس من

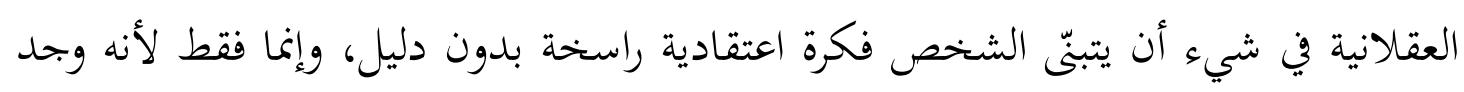
آباءه وأجداده يعتقدوها، إنّ عدم عقلانية هذه الفكرة تكمن في أنّ الاعتقاد يجب أنب أن يبنى

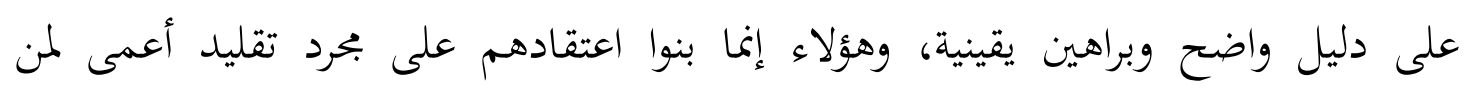

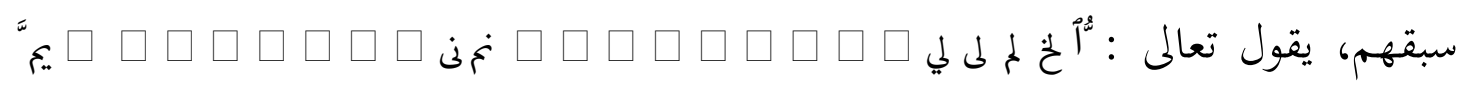

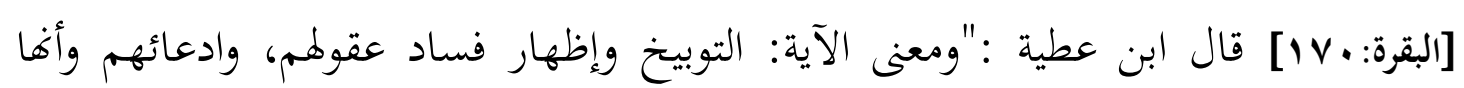

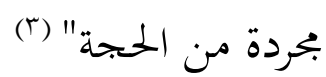

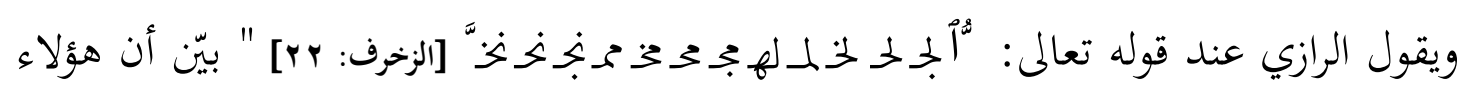

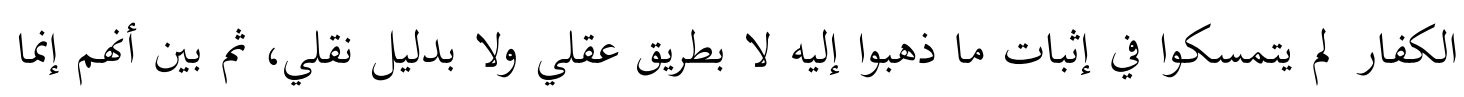

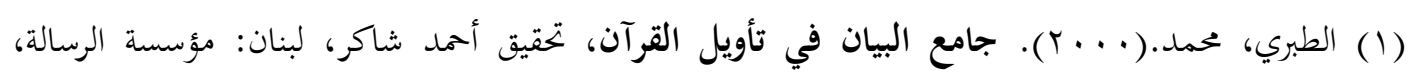
(rTr/IT)

(r) أبو السعود، محمد. (د.ت). إرشاد العقل السليم إلى مزايا الكتاب الكريم، بيروت: دار إحياء التراث

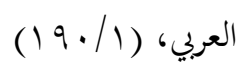

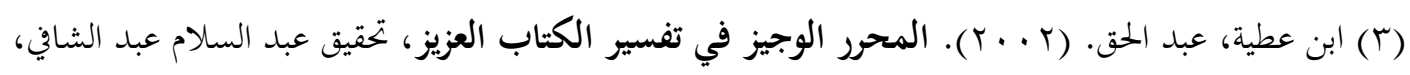

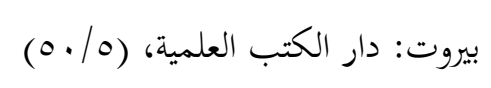


ذهبوا إليه بمجرد تقليد الآباء والأسلاف، وإنما ذكر تعالى هذه المعاني في معرض الذم

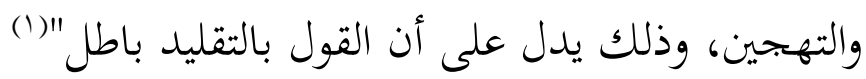

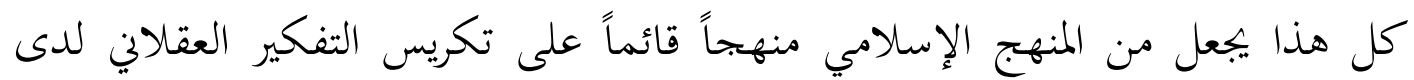

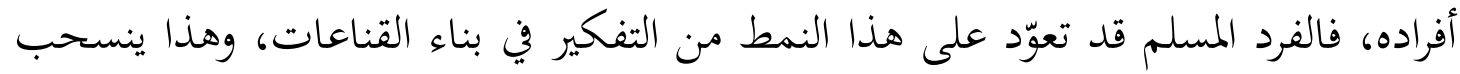
على التفكير في أمور الحياة اليومية.

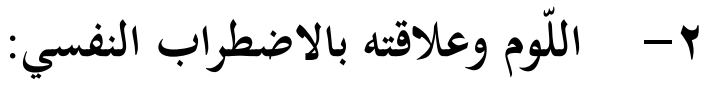

تقدّم أنّ (إليس) يرى أنّ الإنسان غير معصوم من الوقوع في الخطأ، وأنّ أكثر ما يسبب

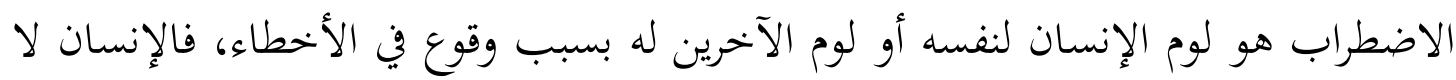

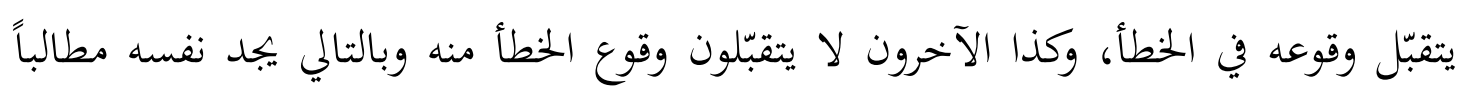
بالكمال دائماً وهذه نظرة غير عقلانية تؤدي إلى الاضطراب النفسي.

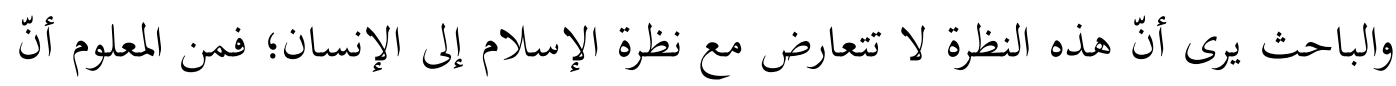

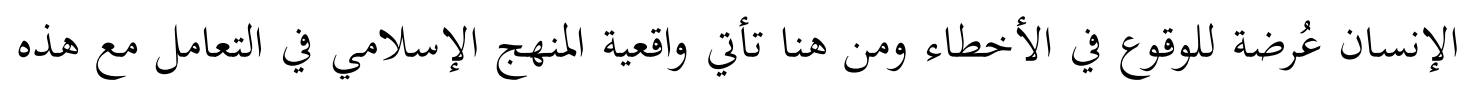
الفكرة غير العقلانية فمن المنطقي أن يقع الإنسان في الخطأ وذلك دليل على إنسانيته وليس دليالً على فشله.

وقطعاً فلم يقصد (إليس) العصمة من الوقوع في الذنوب لأنّ هذا موجود في الإسلام فقط، ولكن المقصود أن الإنسان تقع منه هفوات ويرتكب أخطاء فمن الناس من يبالغ في لوم نفسه، ولوم الآخرين على هذه الأخطاء، ويظل حبيسها مما يؤثر على اتزانه النفسي.

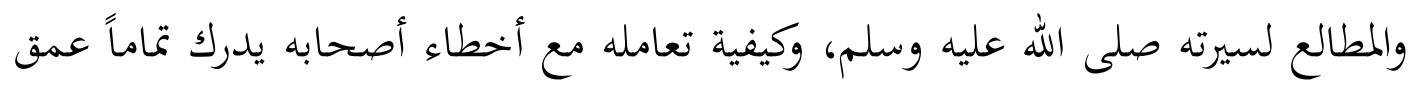
المنهج الإسلامي ومراعاته للصائص الأفراد الانفعالية ومحافظته على الاتزان النفسي للأفراد

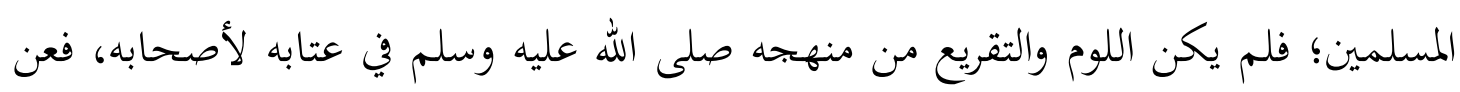
أنس بن مالك رضي الله عنه قال: "عن أنس بن مالك رضي الله عنه قال: لم يكن النبي

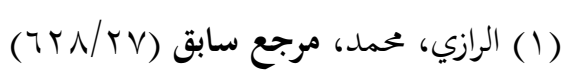


صلى الله عليه وسلم سبّاباً، ولا فحّاشاً، ولا لعِّاناً، كان يقول لأحدنا عند المعتبة: ما له ترب جبينه "(1)

ويصوّر أنس - رضي الله عنه - الصورة التي كان يتعامل بها البي صلى الله عليه وسلم

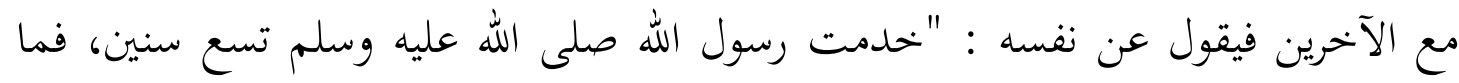

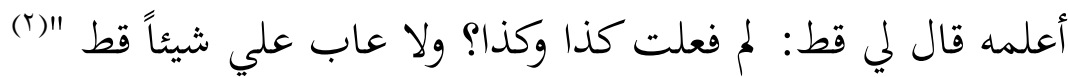
إنّ هذا التصرف منه صلى الله عليه وسلم لم يكن عارضاً في مواقف بسيطة بل كان

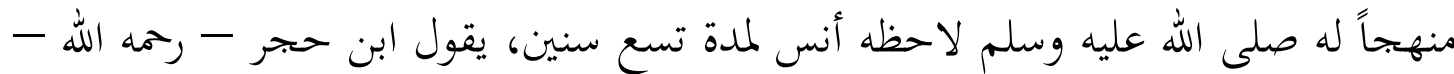

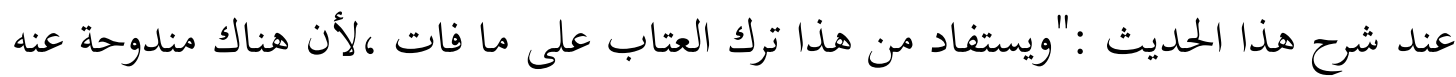

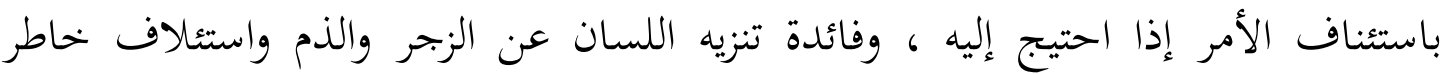

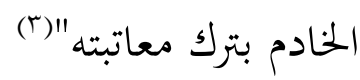
وفي أنموذج آخر يتجلى حُسن تعامله صلى الله عليه وسلم مع أخطاء أصحابه، وبُعدهاه عن لومهم، ومدى مساعدته لهم على البناء النفسي من جديد وتجاوز الاضطراب النفسي،

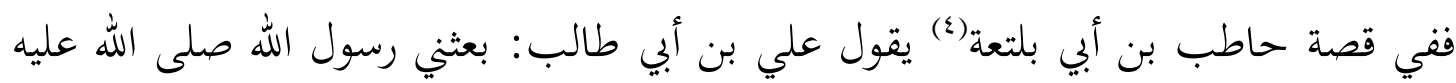

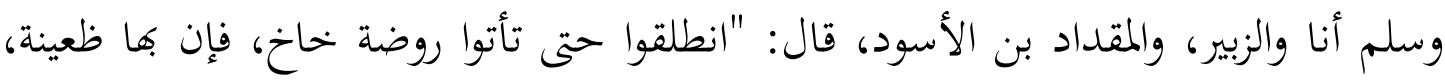

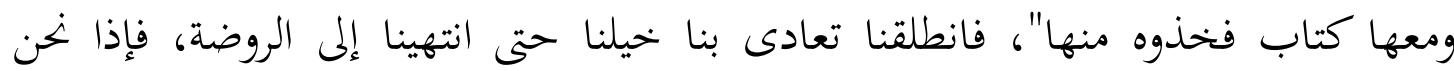

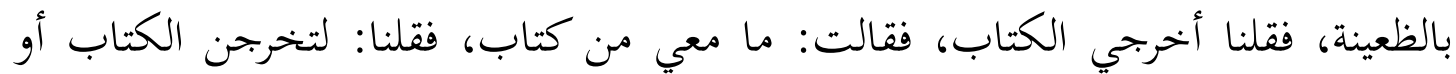

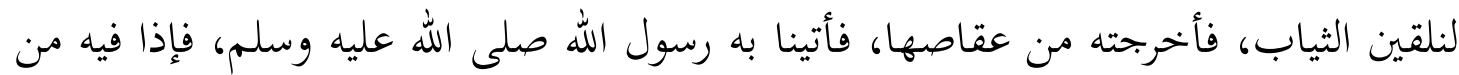

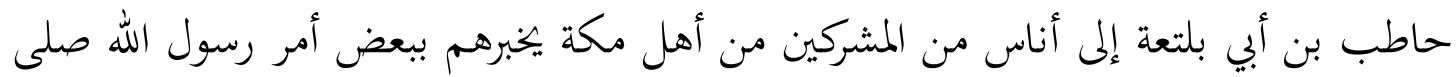

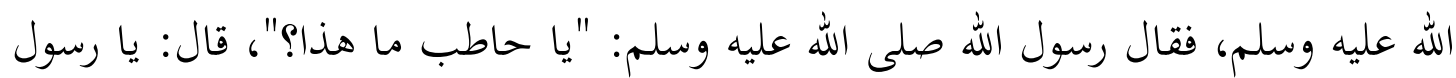

(1) أخرجهه البخاري في كتاب الأدب، باب لم يكن النبي صلى الله عليه وسلم فاحشأ ولا متفششاً، حديث رقم

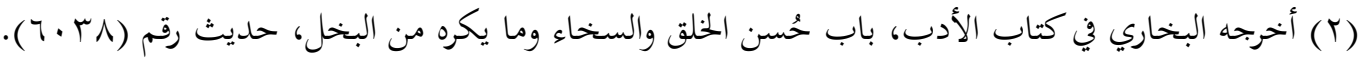

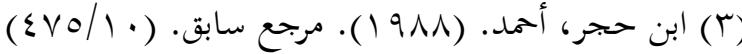

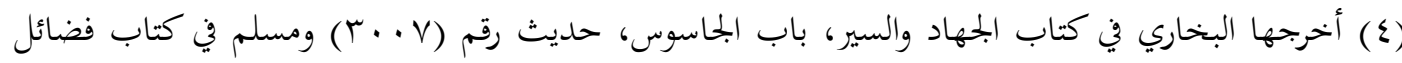

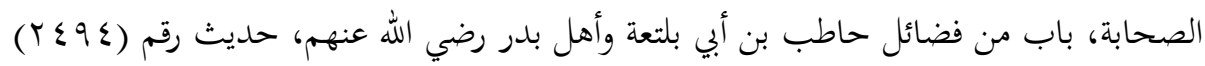


الله، لا تعجل علي إي كنت امرأ ملصقاً في قريش، ولم أكن من أنفسها، وكان من معك من

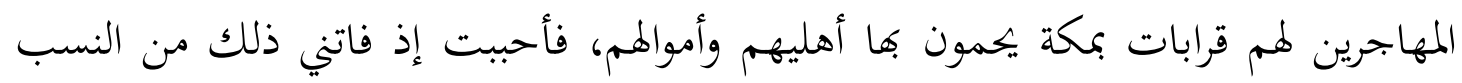

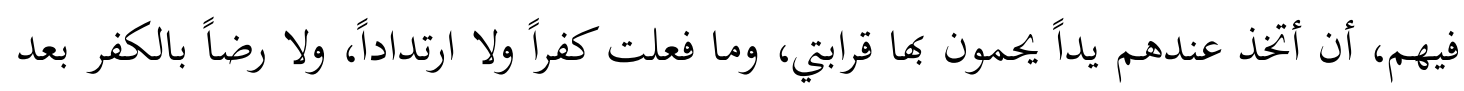

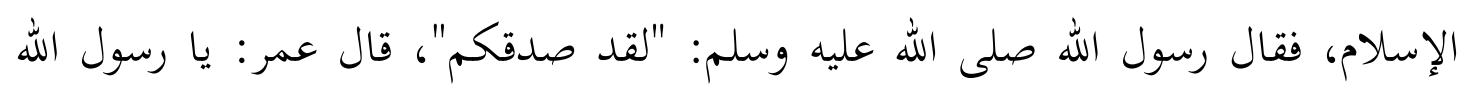

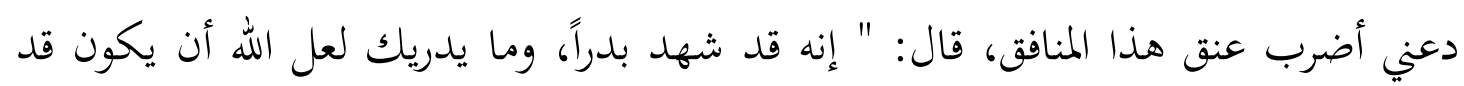

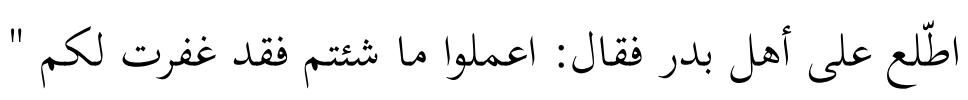

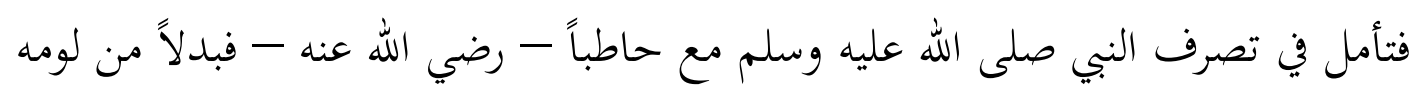
ناقشه في فعله، واستقصى عن الفكرة غير العقلانية التي دفعته إلى هذا التصرف، إنّ الفكريا

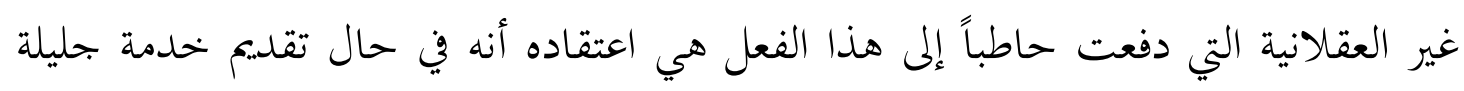
لقريش فإنّ ذلك سيوفر لأسرته الأمن والأمان، وغاب عن ذهنه الفكرة العقلانية وهي حفظ سر المسلمين، وطاعة الله وطاعة رسوله صلى الله عليه وسلم، وأنّ الله هو الحافظ لأسرته.

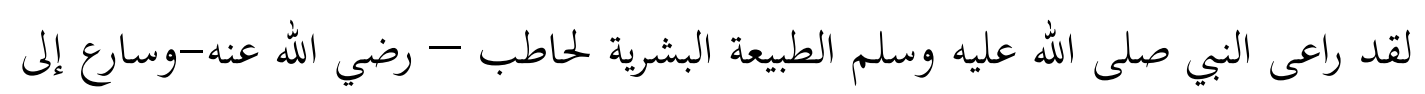

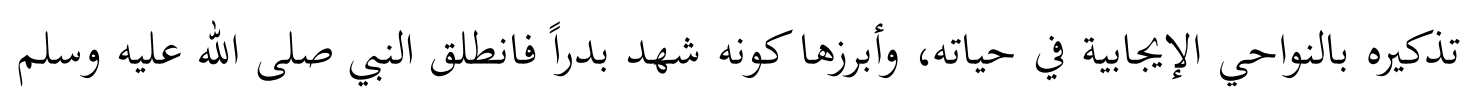

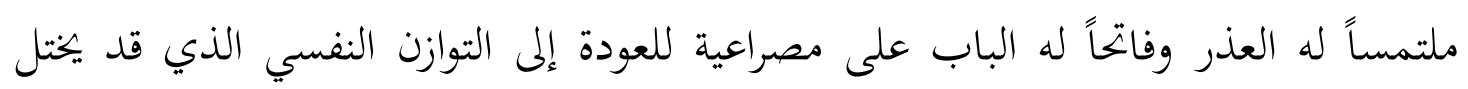
عنده بسبب هذه الفعلة. وهكذا يجب أن يعمل المرشد في ضوء المنهج الإسلامي فيقوم بإعادة التوازن النفسي للمسترشد والعمل على توافقه مع ذاته، وتصحيح نظرته عن نفسه.

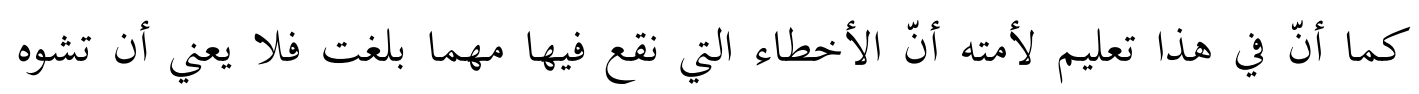

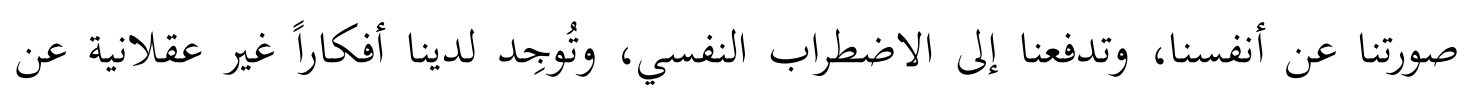
الحياة. إنها واقعية المنهج الإسلامي وتعامله مع الأخطاء ومساعدة الأفراد على بتحاوزها وهذا ما

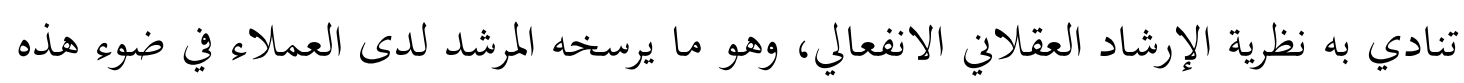
النظرية. وعندما رأى النبي صلى الله عليه وسلم تقصيراً من ابن عمر - رضي الله عنه - في النوافل وأراد أن يلفت نظره إلى ذلك لم يقوم بلومه على التقصير بلفظ صريح، وإنما ذكر النواحي إئ 
الإيجابية التي عنده وأثنى عليه فقال: "نعم الرجل عبد الله لو كان يقوم الليل"(() لقد أوصل له

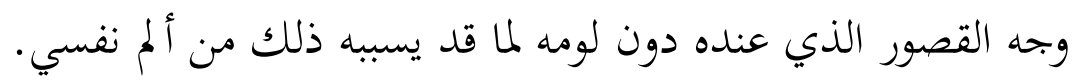

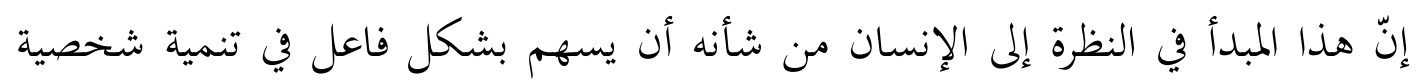
الفرد ووقايته من الاضطراب ففشل الشخص في جانب من جوانب الحياة لا يعني فشله الدائم ولا يجب أن يسبب له القلق والاضطراب لأن باب إصلاح الأخطاء مفتوح والإنسان بطبيعته الوقوع في الأخطاء وبهذا يتحقق الاطمئنان النفسي للفرد فلا يصح تحميله أو تحميل نفسه ما لا يطيق من اللوم والتقريع.

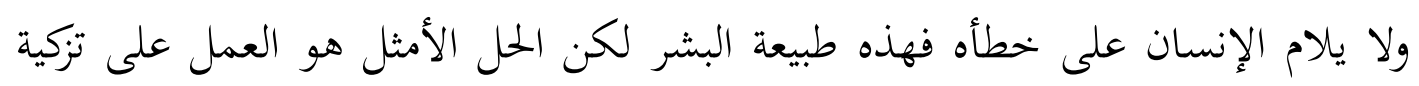

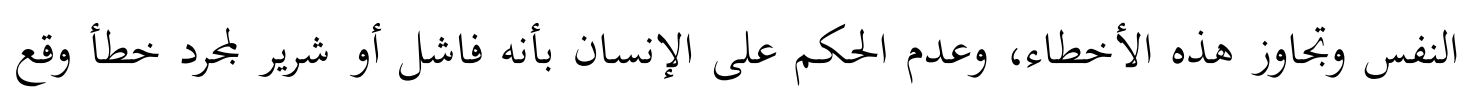
فيه وهذه واقعية المنهج الإسلامي. ثالثاً: نقد أساليب الإرشاد لنظرية الإرشاد العقلاني الانفعالي في ضوء المنهج الإسالامي: يعتمد المرشد في ضوء هذه النظرية على أسلوب رئيس هو تحديد الأفكار غير العقلانية ثم مهاجمتها، وتفنيدها ثم بناء أفكار عقلانية مكانها، وهنا يتفوق المنهج الإسلامي في كونه يعتمد على المنهج البنائي الذي يقوم على بناء الأفراد نفسياً وتصحيح أفكارهم تحاه الحياة

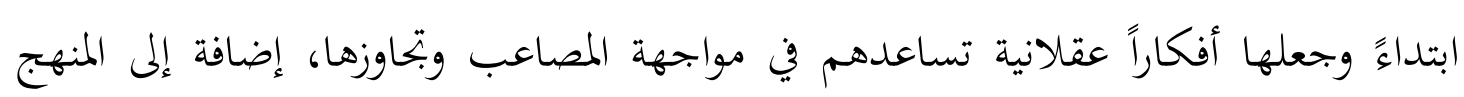
العلاجي في علاج ما قد يحصل من اضطراب لدى الفرد بسبب الأفكار غير العقلانية.

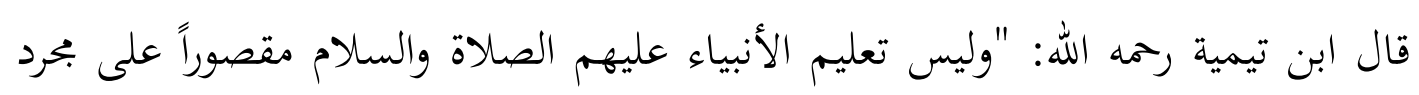

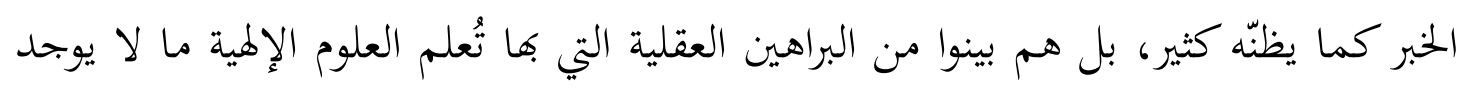

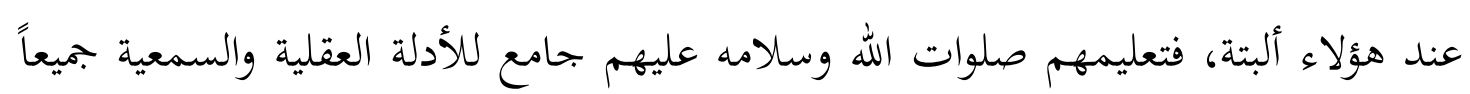
بخلاف الذين خالفوهم فإنّ تعليمهم غير مفيد للأدلة العقلية والسمعية مع ما في فئمات نفوسهم من الكبر الذي ما هم ببالغيه" (؟)

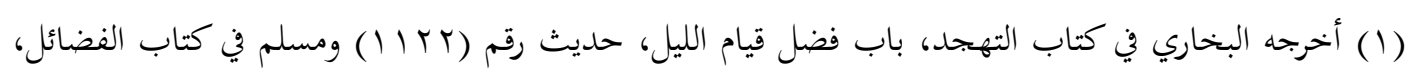

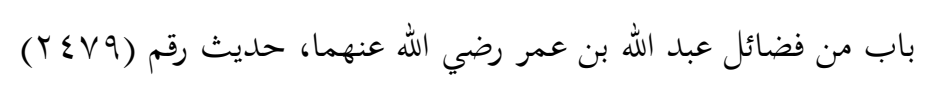

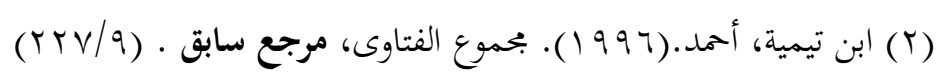

r人 
فلقد اهتم الإسلام بتصحيح المفاهيم والتصورات عن الحياة وأحداثها لدى الفرد المسلم،

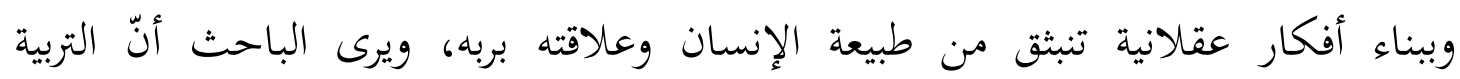
الإسلامية اتخذت في ذلك منهجين :

أولاً: المنهج البنائي : وفيه يتم بناء الأفكار العقلانية نخو الحياة ونهو الصعوبات التي

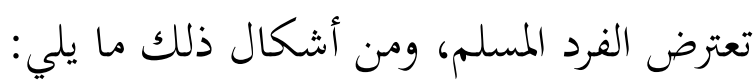
1- بناء أفكار إيجابية نحو المصاعب والابتلاءات:

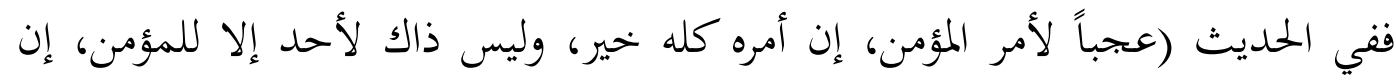

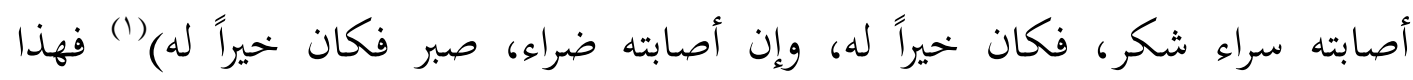

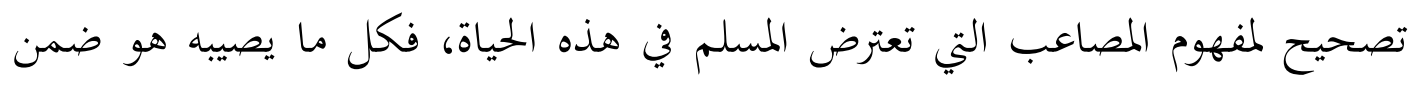

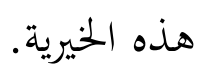

r- ب بناء أفكار إيجابية نحو حقيقة الحياة الدنيا:

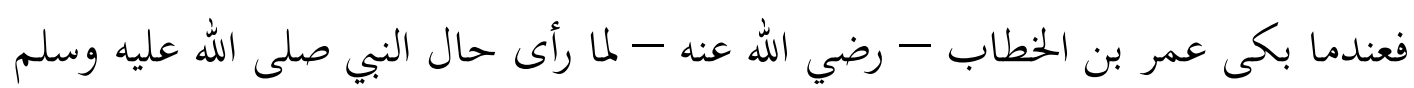

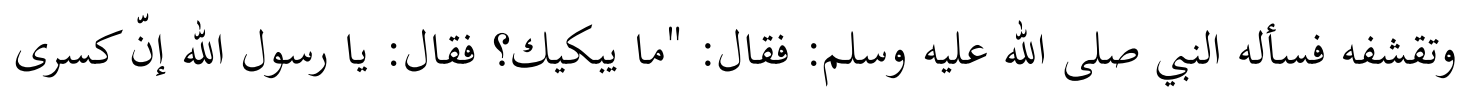

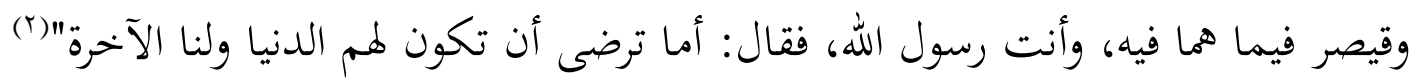

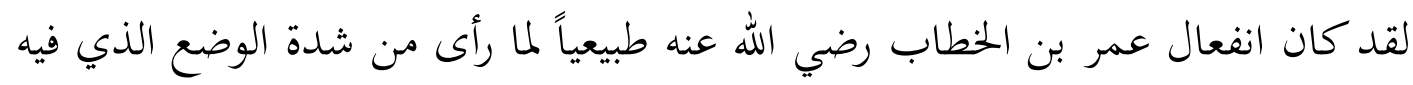

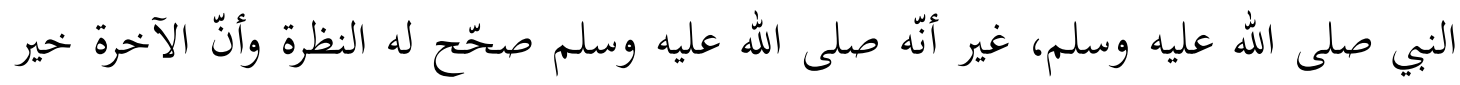

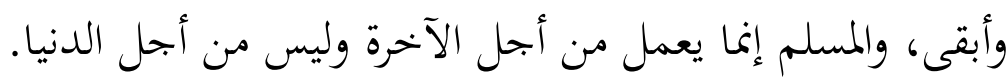

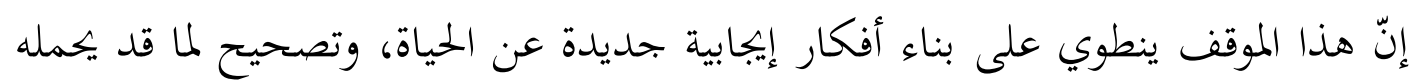

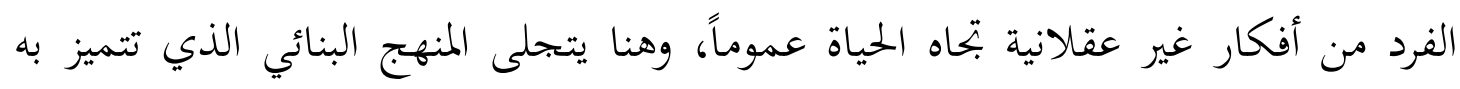
التربية الإسلامية، إنّ غرس هذه المفاهيم في نفوس الأفراد وفي عقولهم وتربيتهم عليها كفيل

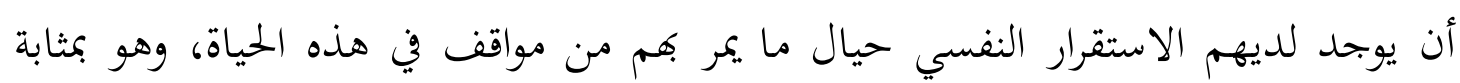

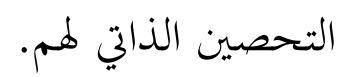

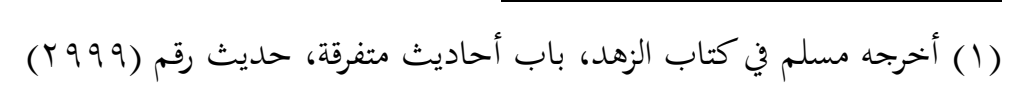

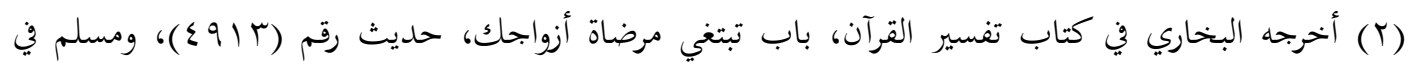

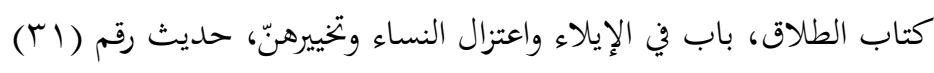


وفي موقف آخر يقوم صلى الله عليه وسلم بتصحيح النظرة عن الحياة الدنيا ، فعن عبد الله بن مسعود، قال: نام رسول الله صلى الله عليه وسلم على حصير فقام وقد أثّر في جنبه،

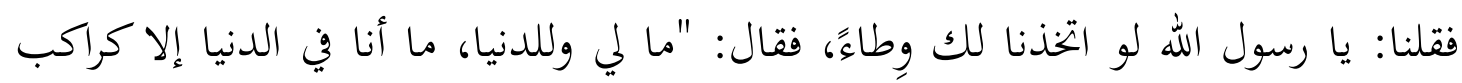

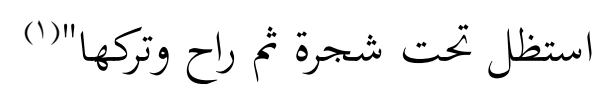

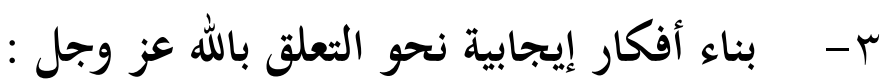

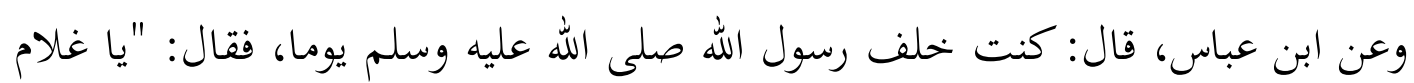
إني أعلمك كلمات، احفظ الله يمفظك، احفظ الله بتحه تجاهك، إذا سألت فاسأل الله،

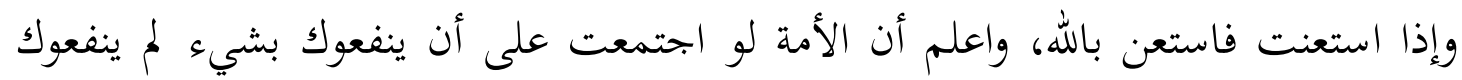

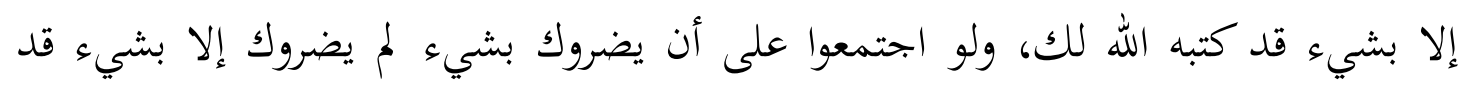

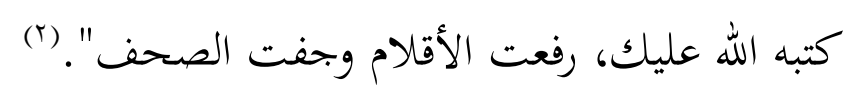
وهنا تصحيح آخر أنّ كل ما يصيب الإنسان هو مما كتبه الله عليه وبالتالي فلا ينزعج المسلم مما يعترض طريقه في هذه الدنيا.

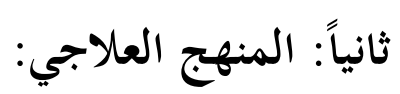
وهذا على مستوى الأشخاص فقد علّم النبي صلى الله عليه وسلم أصحابه كيف يتحرون عن الأفكار غير العقلانية التي تسبب لهم الاضطراب، وكيفية تفنيدها، ثم القيام ببناء أفكار

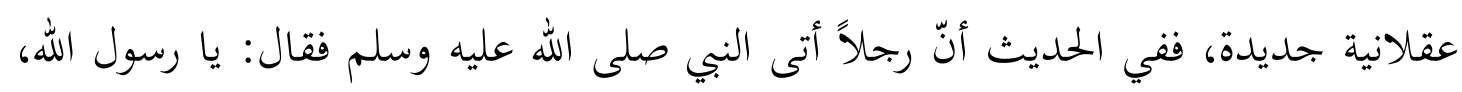

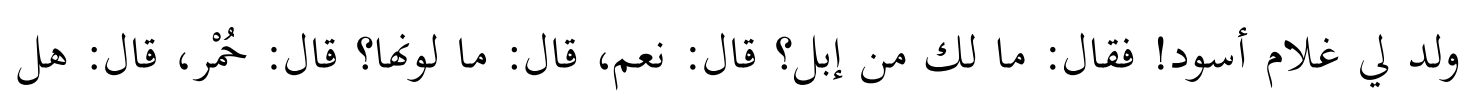

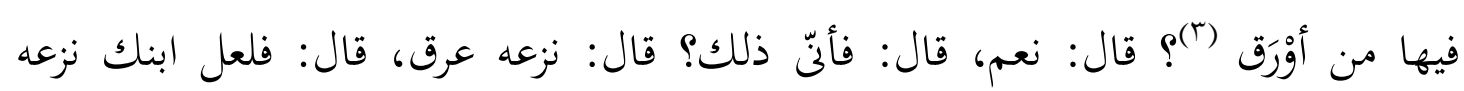
عرق" (๕) فن (؟)

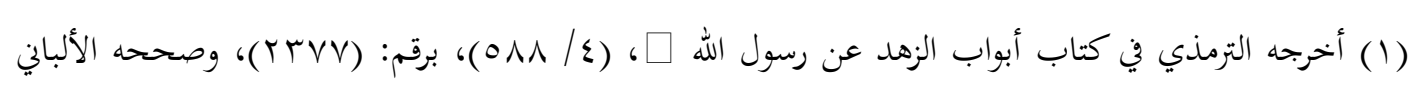

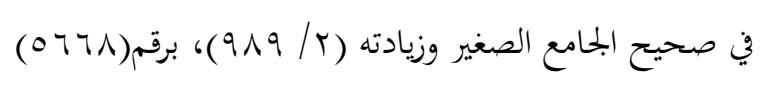

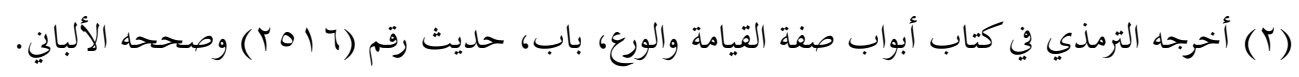

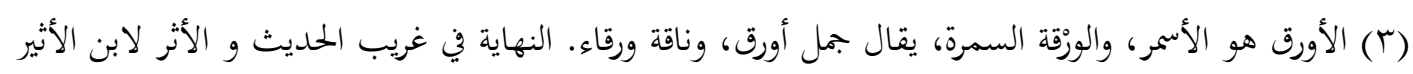

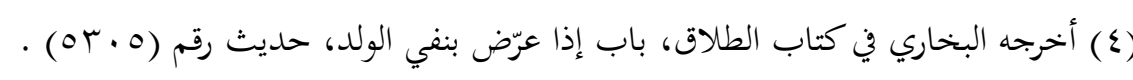


لقد استخدم النبي صلى الله عليه وسلم عناصر البيئة المخيطة واستند إلى الخلفية

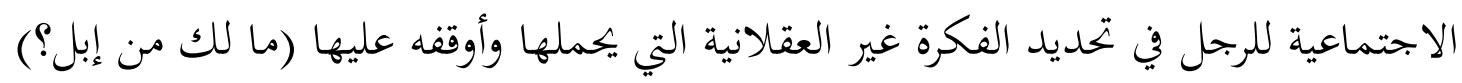
تم بيّن له الفكرة العقلانية (فلعل ابنك نزعه عرق).

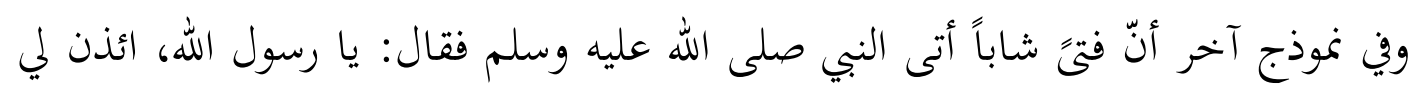

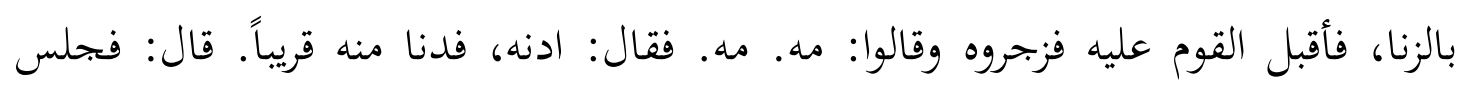

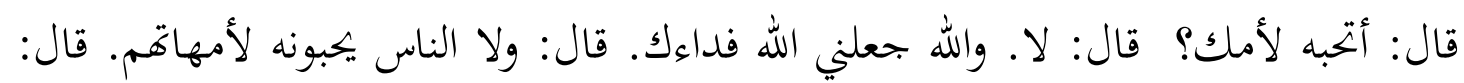

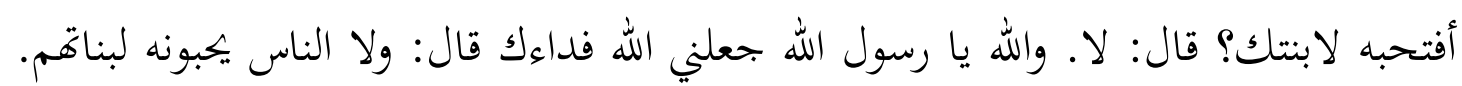

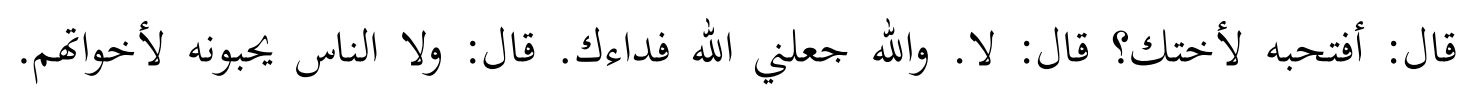

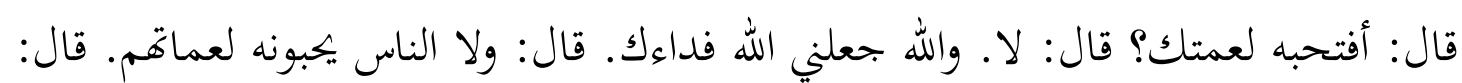

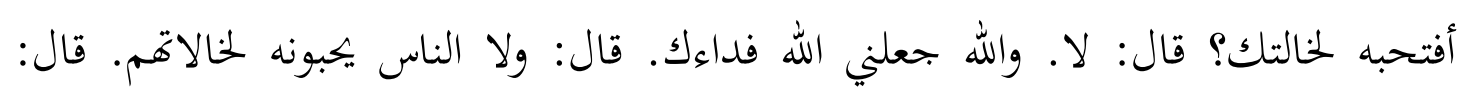
فوضع يده عليه وقال: اللهم اغفر ذنبه وطهر قلبه، وحصن فرجه، قال: فلم يكن بعد ذلك الفتى يلتفت إلى شيء"(1) لقد حاور النبي صلى الله عليه وسلم الشاب حواراً عقلانياً وبدأ بتفنيد الفكرة شيئاً فشيئاً فلا

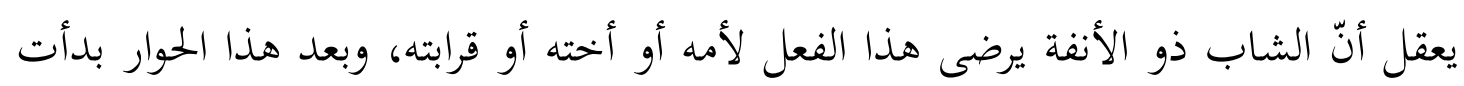
الفكرة تتضح معالمها. إنّ إيقاف المرشد للمسترشد على الأفكار غير العقلانية التي تسبب له الاضطراب أمر في

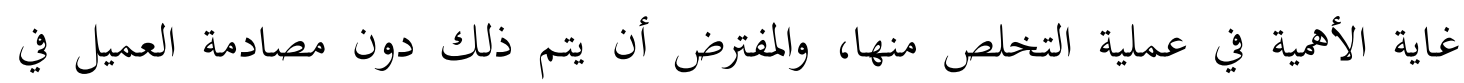
معتقداته حتى لا يبدي مقاومة للعملية الإرشادية.

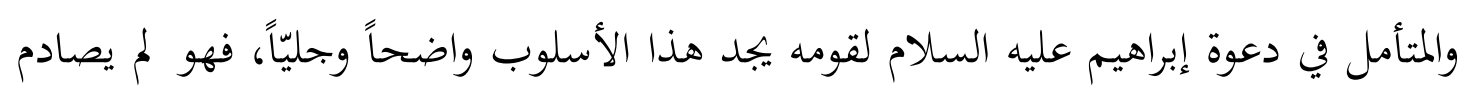

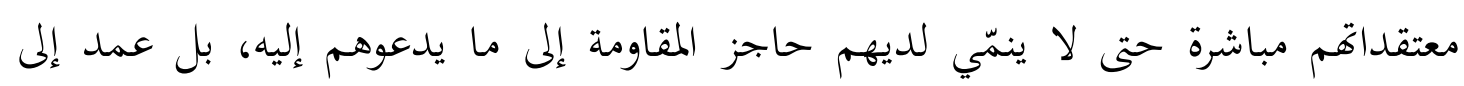

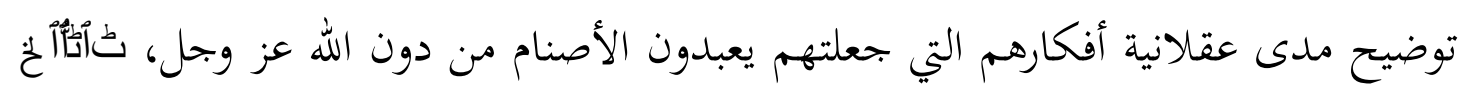

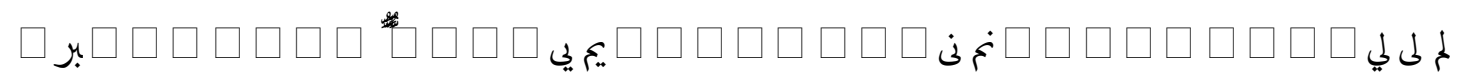

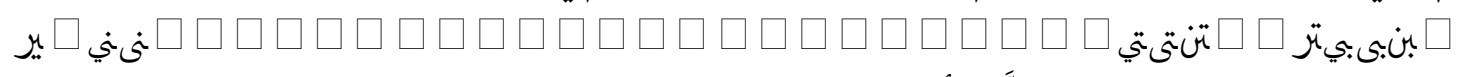

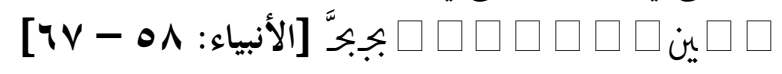

(1) أخرجه أحمد في المسند، حديث رقم (YTII) 


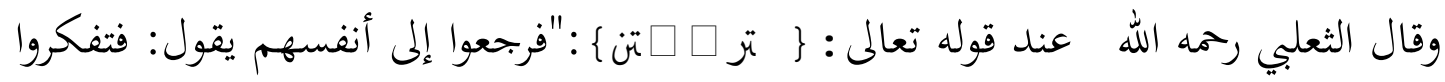

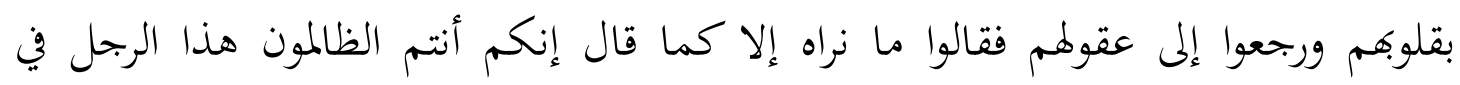

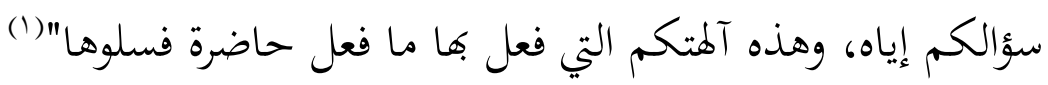

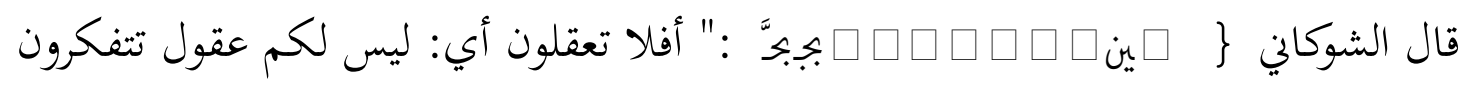

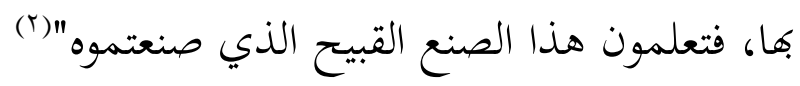

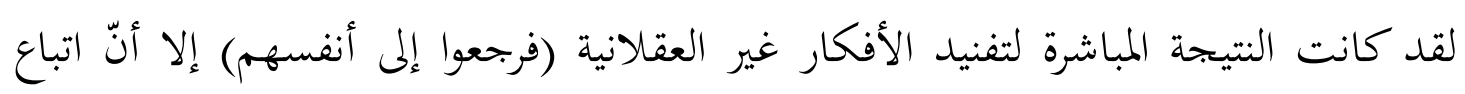

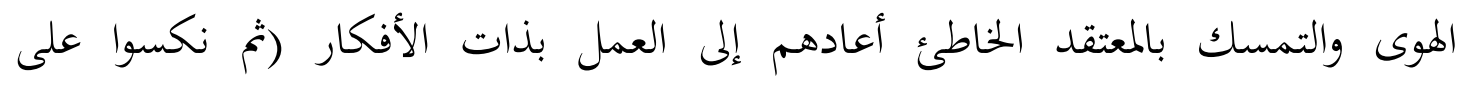
رؤوسهم).

وفي موقف آخر لإبراهيم عليه السلام مع قومه، يمارس ذات الأسلوب فيجعلهم يتحرون عن

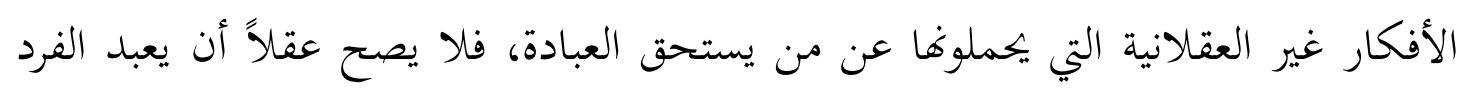

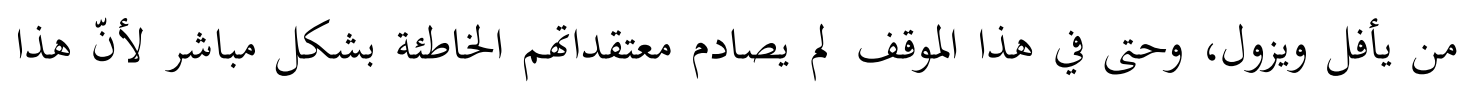

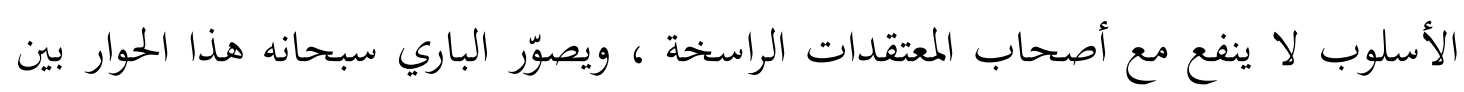

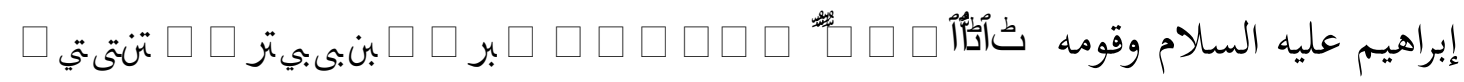

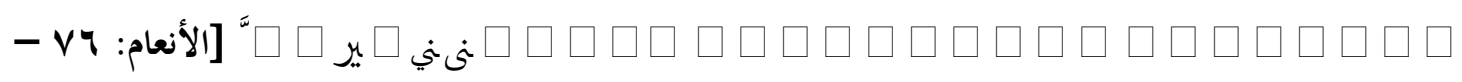

[v^

ومن هنا فإنّ هذا أسلوب تحديد الأفكار غير العقلانية وتفنيدها، ثم بناء أفكار عقلانية

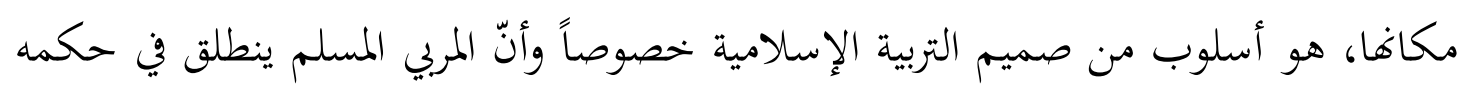

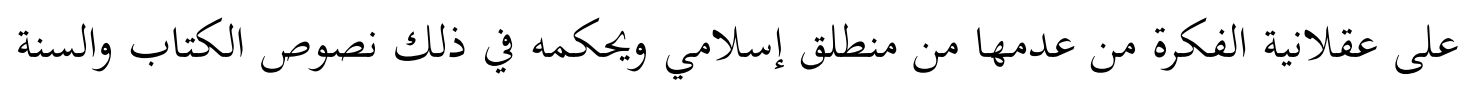
وليس ما يراه المرشد عقلانياً أو غير عقلاني.

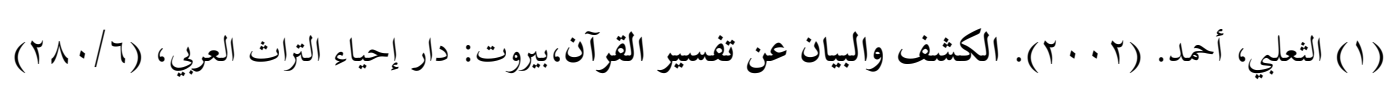

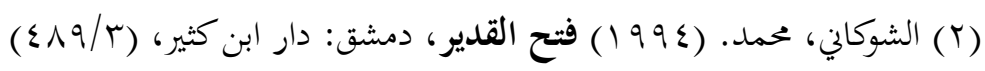


أولاً: النتائج:

- تختلف نظرية العلاج العقلاني الانفعالي عن نظرة المنهج الإسلامي إلى الإنسان وقد تبيّن شمولية نظرة المنهج الإسلامي وواقعيته.

- تتفق نظرية الإرشاد العقلاني الانفعالي مع المنهج الإسلامي في إقرار حرية الفرد في استخدام طريقة التفكير التي يريد سواء كانت عقلانية أو غير عقلانية.

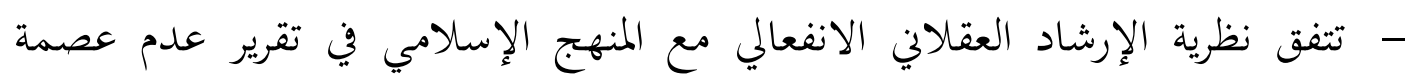
الإنسان من الوقوع في الأخطاء.

- تتفق نظرية الإرشاد العقلاني الانفعالي مع المنهج الإسلامي في عدم استخدام اللوم

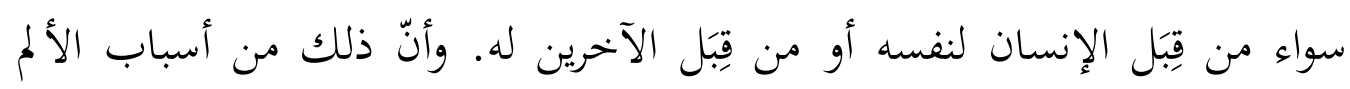
النفسي.

- لقد أوضح البحث سبق المنهج الإسلامي في أسلوب تحديد الأفكار غير العقلانية

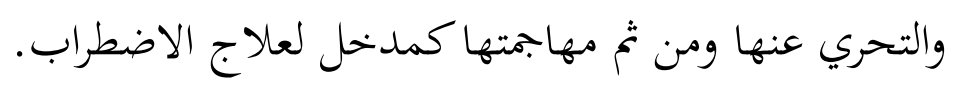

- يتفوق المنهج الإسلامي في طريقة تعاطيه مع الأفكار غير العقلانية حيث سلك

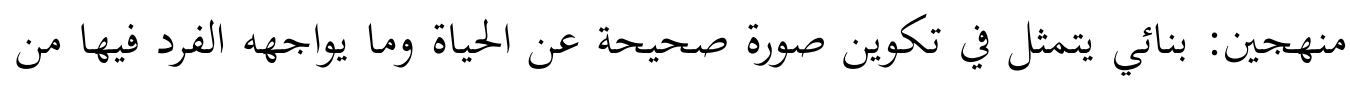

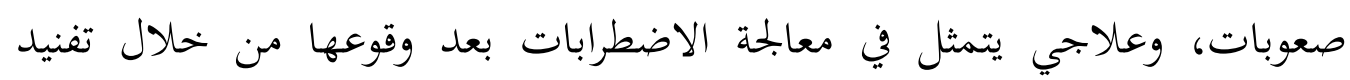
الأفكار غير العقلانية ومهاجمتها. التوصيات : في ضوء نتائج الدراسة فإنّ الباحث يوصي بما يلي :

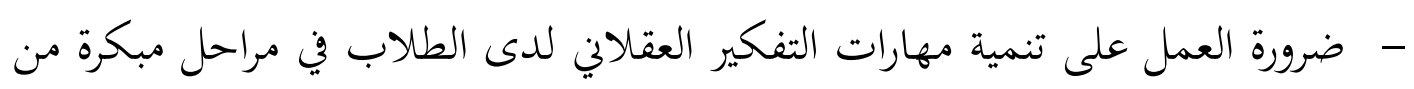
التعليم من خلال مناهج التعليم والأنشطة اللاصفية.

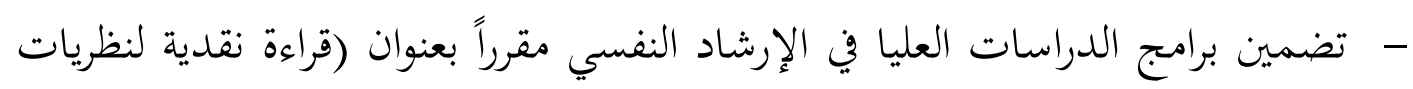
الإرشاد النفسي في ضوء المنهج الإسلامي) 
- تقديم دورات علمية لكافة شرائح البحتمع فيما يتعلق بالأفكار غير العقلانية من حيث

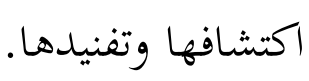

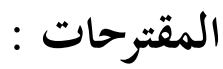

يقترح الباحث إجراء الدراسات التالية: 1- مدى إلمام المرشدين الطلابيين في المدارس الثانوية بكفاهيم الإرشاد العقلاني

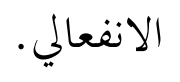

r- الإرشاد العقلاني الانفعالي من خلال دعوة الأنبياء لأقوامهم.

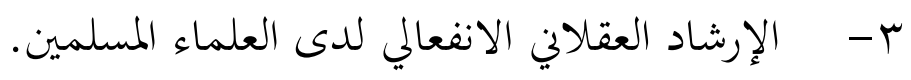
ع - منهج التربية الإسلامية في التعامل مع الأفكار غير العقلانية. 


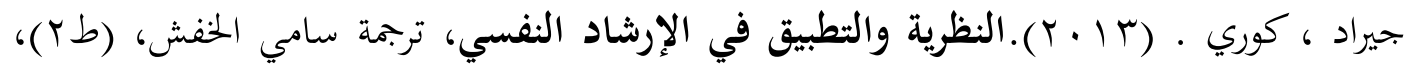

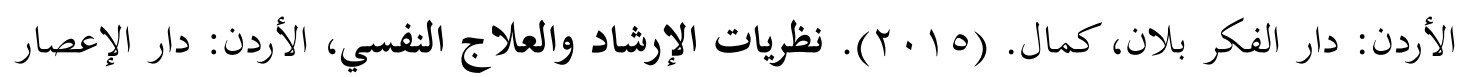
العلمي.

ابن تيمية، أحمد. (1997 (19). مجموع فتاوى شيخ الإسلام، المملكة العربية السعودية: بحمع الملك

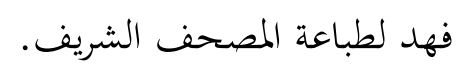

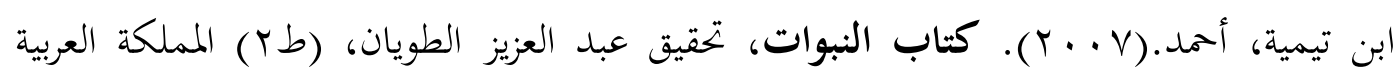
السعودية: الجامعة الإسلامية. ابن حجر، أحمد بن علي. (911 (1). فتح الباري بشرح صحيح البخاري. (ط آ). القاهرة: دار الريان.

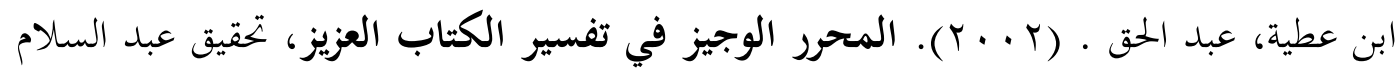

$$
\text { عبد الشافي، بيروت: دار الكتب العلمية. }
$$

أبو السعود، محمد. (د.ت). إرشاد العقل السليم إلى مزايا الكتاب الكريم، بيروت: دار إحياء

$$
\text { التراث العربي. }
$$

بلعسلة، فتحية. (ع ا · ؟). الارشاد العقلاني الانفعالي لـ أليس : مبادئه ، أسسه وتطبيقاته في العملية

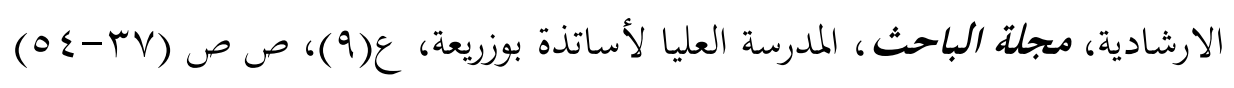

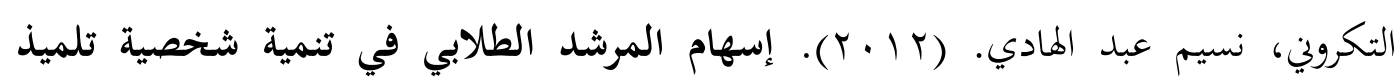

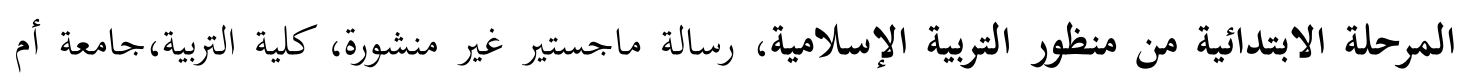
القرى.

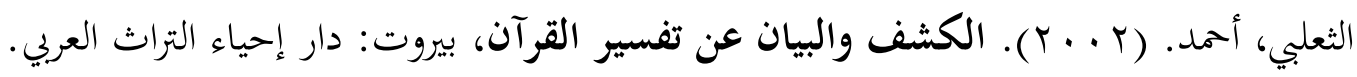

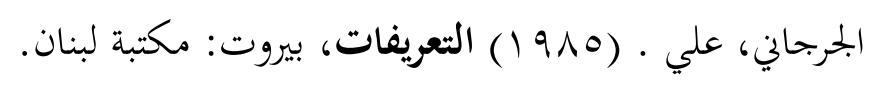

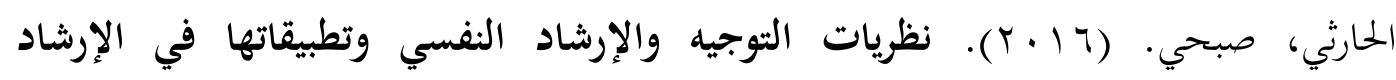
المدرسي. الدمام: مكتبة المتنبي.

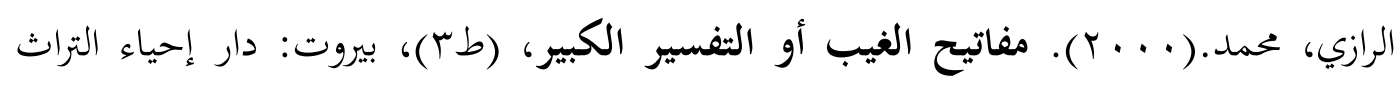




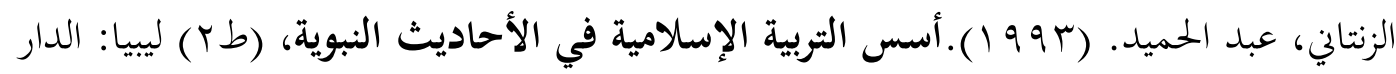
العربية للكتاب، ص (11) (11). الزهراني، مسفر.(1 . ب). التوجيه و الارشاد النفسي في القرآن الكريم و السنة النبوية،

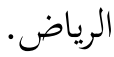

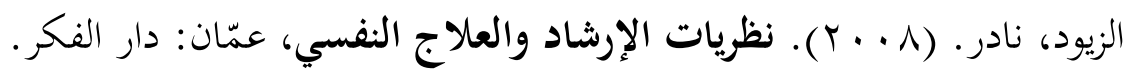

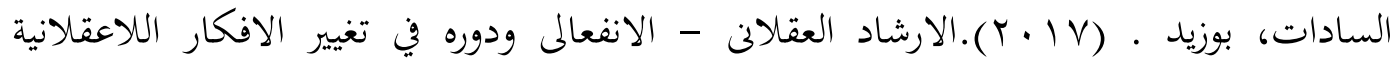

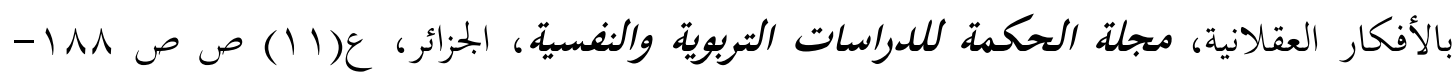
$r \cdot \Lambda$ السفاريني، أحمد. (919 (1). لوامع الأنوار البهية وسواطع الأسرار الأثرية، (طॅ)، سوريا: المكتب الإسلامي الشناوي، محمد محروس. (د.ت). نظريات الإرشاد والعلاج النفسي، دار غريب: مصر.

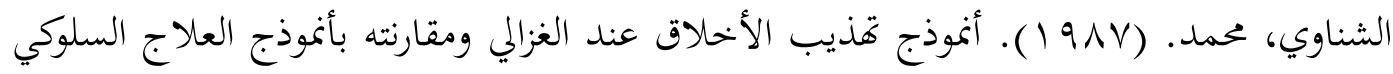

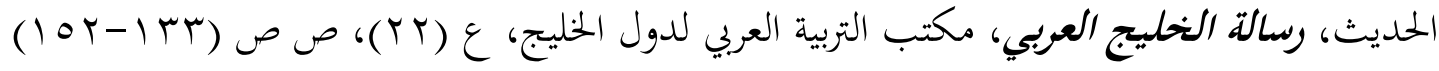

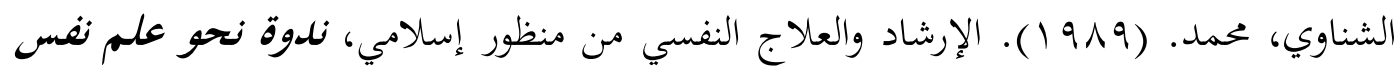
إسلامي، المعهد العالمي للفكر الإسلامي،القاهرة. ضمن كتاب بحوث في التوجيه الإسلامي للإرشاد

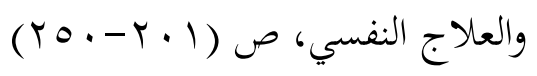

الشناوي، محمد. (1991). الأهداف العامة لمساعدة الأفراد على مواجهة مشكلاتمم النفسية كما تعرضها نظريات الإرشاد والعلاج النفسي الغربية دراسة تقويمية في ضوء المنهج الإسلامي، نلدوة التأصيل

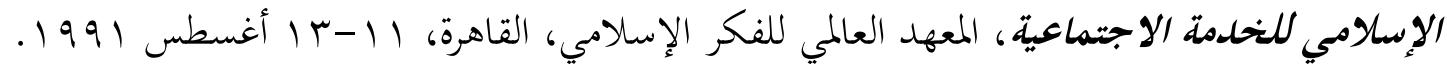
الشناوي، محمد. (ب991 ). التصوير الإسلامي لنماذج السلوك البشري : دراسة نفسية إسلامية،

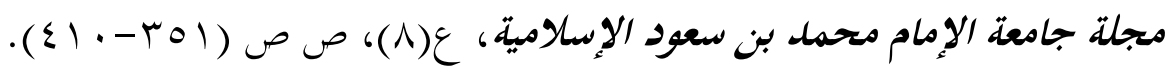

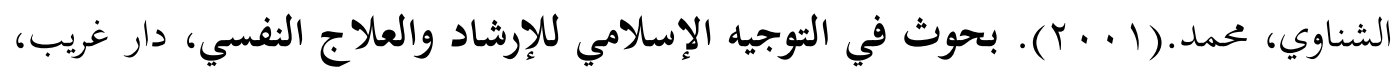
القاهرة.

$$
\text { الشوكاني، محمد. (ع (99 1) فتح القدير، دمشق: دار ابن كثير. }
$$

ضيف، حليمة. (10 · ب). الأفكار العقلانية واللاعقلانية حسب نظرية إليس (ELLIS)، مجلة جيل العلوم للدراسات الإنسانية والاجتماعية، مركز جيل البحث العلمي، الجزائر، ع(· (1).

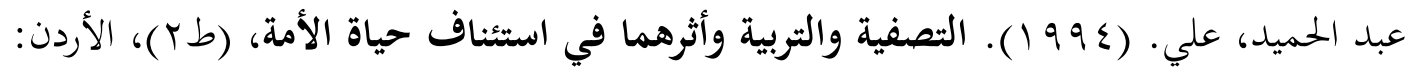




$$
\begin{aligned}
& \text { فودة، حلمي، وصالح، عبد الرحمن. (911 (1). المرشد في كتابة البحوث التربوية. بيروت: دار } \\
& \text { العلم للمالايين. } \\
& \text { قلعجي، محمد رواس. (797 (99). طرق البحث في الدراسات الإسلامية. بيروت: دار النفائس. } \\
& \text { الماوردي، علي. (9 1 • (T). أدب الدين والدنيا، دار المناهج. }
\end{aligned}
$$

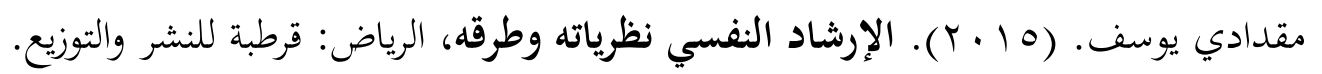

$$
\begin{aligned}
& \text { Albert Ellis: The theory of rational guidance, Albert Ellis Institute (AEI) }
\end{aligned}
$$

https://store.albertellis.org/products/60-years-of-aei-fundraiser-event 